\title{
DIAGNÓSTICO AMBIENTAL E ANÁLISE TEMPORAL DA ADEQUABILIDADE DO USO E COBERTURA DO SOLO NA BACIA DO RIBEIRÃO DOS MARINS, PIRACICABA - SP
}

\section{CATIA ANDERSEN CASAGRANDE}

Dissertação apresentada à Escola Superior de Agricultura "Luiz de Queiroz”, Universidade de São Paulo, para obtenção do título de Mestre em Ecologia de Agroecossistemas.

P I R A C I C A B A

Estado de São Paulo - Brasil

Agosto - 2005 


\section{DIAGNÓSTICO AMBIENTAL E ANÁLISE TEMPORAL DA ADEQUABILIDADE DO USO E COBERTURA DO SOLO NA BACIA DO RIBEIRÃO DOS MARINS, PIRACICABA - SP}

\section{CATIA ANDERSEN CASAGRANDE}

Engenheiro Ambiental

Orientadora: Profa. Dra. MARIA VICTORIA RAMOS BALLESTER

Dissertação apresentada à Escola Superior de Agricultura “Luiz de Queiroz”, Universidade de São Paulo, para obtenção do título de Mestre em Ecologia de Agroecossistemas.

P I R A C I C A B A

Estado de São Paulo - Brasil

Agosto - 2005 
Dados Internacionais de Catalogação na Publicação (CIP) DIVISÃO DE BIBLIOTECA E DOCUMENTAÇÃO - ESALQ/USP

Casagrande, Catia Andersen

Diagnóstico ambiental e análise temporal da adequabilidade do uso e cobertura do solo na bacia do Ribeirão dos Marins, Piracicaba - SP / Catia Andersen Casagrande. - Piracicaba, 2005.

136 p. : il.

Dissertação (Mestrado) - - Escola Superior de Agricultura Luiz de Queiroz, 2005.

1. Bacia hidrográfica 2. Cobertura do solo 3. Ecologia da paisagem 4. Erosão

5. Geoprocessamento 6. Proteção ambiental 7. Uso do solo I. Título

CDD 333.91

"Permitida a cópia total ou parcial deste documento, desde que citada a fonte - O autor" 
Ofereço esta dissertação a Deus e dedico a minha família, que me apoiou para concluir esta importante etapa da minha vida. 


\section{AGRADECIMENTOS}

Agradeço a Deus por ter me abençoado e sustentado em todos os momentos da minha vida.

A Profa. Dra. Maria Victoria Ramos Ballester, agradeço pela orientação, ajuda, confiança e paciência.

Ao Prof. Dr. Reynaldo Luiz Victória e a Emília Hamada pela ajuda e sugestões feitas.

À FAPESP pela concessão da bolsa de estudo para desenvolver este trabalho.

Ao Programa de Pós-Graduação Interunidades em Ecologia de Agroecossistemas (CENA/ESALQ), pela oportunidade de desenvolver este trabalho.

A Regina Freitas pela ajuda com os papéis, cartas e solicitações do programa e a Sílvia pela revisão da formatação.

Ao DAEE, SEMAE, SEMA, IPPLAP, IBGE, CETESB, CATI, DPRN, CTH, Vigilância Epidemiológica, IGC, Instituto Florestal, UFSCAR e aos demais órgãos, instituições e pessoas que me auxiliaram na etapa de levantamento de dados, agradeço pela atenção, ajuda, informações e dados fornecidos.

Ao Jose Eduardo Bovi, Airton, Karina, Jair, Alex, Márcio, Maria, Sebastião, Gilberto, Nevile, Beto, Nanci, Érica, Zezé, Carlos, Ado, Cláudio Lisi, André, Moretti, Rita, Prof. Jorge Raffo, Prof. Francisco Lombardi Neto, Prof. Rubens Angulo Filho, Prof. Mário Tomazello Filho, Prof. Donzeli, Prof. Luiz Antonio Martinelli, Simone Ranieri, Ranulfo, Aderson, Rodrigo, Igo Lepsch, Vania Korman, Kátia, Ariovaldo e Alexandre pelas informações, ajuda, atenção e disposição.

A Letícia, Daniel, André, Laís, Ana Luiza, Fabrício (in memorian) e Ana Paula pela paciência, colaboração e por toda ajuda fornecida no desenvolvimento das atividades no laboratório de Geoprocessamento.

Ao pessoal do laboratório de Geoprocessamento e de Ecologia Isotópica do CENA, José Mauro, Vania Neu, Fátima, Adriana, Michelle, Pira, Santiago, Erich, Ana Carolina, Daniel, André, Michela, Ana, Sérgio, Marcos, Nei, Edmar, Edgar, Malu, Salomão, Gabi, Daniela, Jean, Zebu, Neusa, Pereira e Jorginho pela ajuda, companheirismo, amizade e colaboração. 
A Adriana Furlan, Débora, Rosa Maria, Maria Helena, Karina, Saulo, Márcio, Paula, Alexandre, Lúcia, Kátia, Laís, Marisol, Letícia e demais amigos pelo incentivo nesta caminhada.

Aos meus pais João e Márcia e as minhas irmãs Alice e Cíntia pelo apoio, ajuda, carinho e incentivo.

Aos meus familiares e amigos pelo carinho e incentivo para a realização dos meus objetivos e sonhos.

Aos professores e pesquisadores pelas contribuições e atenção dedicada.

A todos aqueles que, de alguma forma, contribuíram para a realização deste trabalho. 
"O coração do homem traça o seu caminho, mas o Senhor lhe dirige os passos”. Provérbios 16:9 “Todo prudente procede com conhecimento, mas o tolo expõe a sua insensatez”. Provérbios 13:16 


\section{SUMÁRIO}

Página

LISTA DE FIGURAS ........................................................................ viii

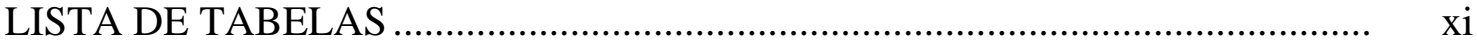

RESUMO .................................................................................................

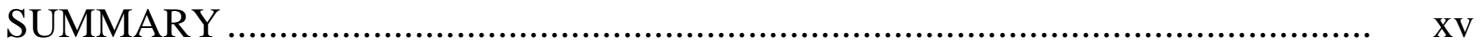

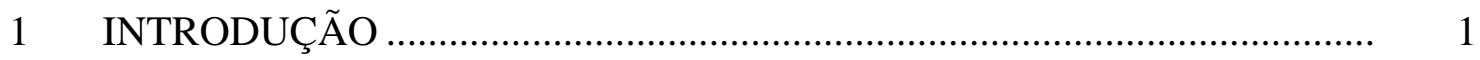

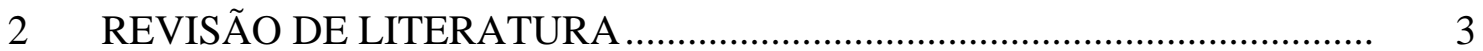

3 MATERIAL E MÉTODOS …................................................................. 9

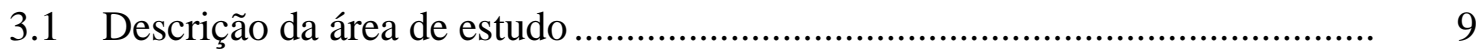

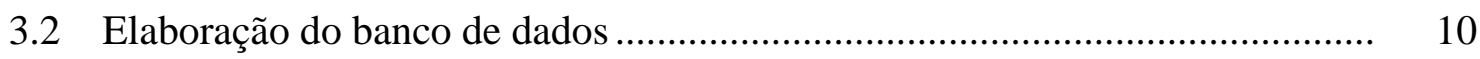

3.3 Diagnóstico ambiental........................................................................ 11

3.4 Análise das mudanças ............................................................................ 42

3.5 Adequabilidade do uso e cobertura do solo ................................................ 43

3.6 Análise das relações ............................................................................... 44

4 RESULTADOS E DISCUSSÃO ........................................................... 45

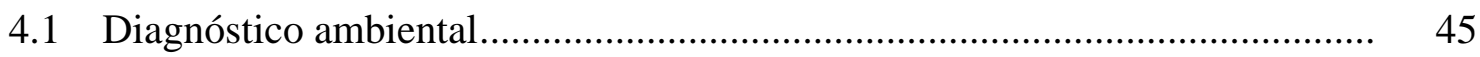

4.2 Análise das mudanças .......................................................................... 89

4.3 Adequabilidade do uso e cobertura do solo ............................................... 107

4.4 Análise das correlações .......................................................................... 121

4.5 Sugestões para atividades futuras......................................................... 122

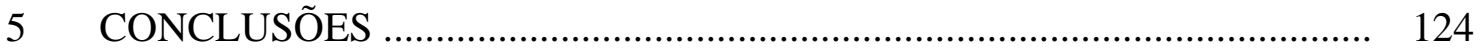

REFERÊNCIAS BIBLIOGRÁFICAS...................................................... 126 


\section{LISTA DE FIGURAS}

Página

1 Localização da área de estudo, bacia do ribeirão dos Marins ............................ 9

2 Localização dos postos pluviométricos, vertedor e ponto final da bacia dos Marins utilizados para a estimativa das vazões naturais.................................. 14

3 Localização dos pontos de coleta e setores da bacia do ribeirão dos Marins .. 20

4 Mapa de referência utilizado para correção geométrica das fotografias aéreas da bacia dos Marins ……………………................................................... 25

$5 \quad$ Rede de drenagem da bacia do ribeirão dos Marins .......................................... 46

6 Vazões médias na bacia do ribeirão dos Marins .................................................. 46

7 Modelo Digital de Elevação do Terreno da bacia do ribeirão dos Marins ...... 48

8 Declividade (em porcentagem) da bacia do ribeirão dos Marins...................... 49

9 Fotografias aéreas de 1940, 1962, 1978, 1995 e 2000 mostrando o processo de urbanização de uma área da bacia do ribeirão dos Marins.......................... 51

10 Origem da água utilizada na irrigação das hortaliças na bacia do ribeirão dos Marins

11 Localização das outorgas concedidas e dos produtores de hortaliças identificando a origem da água utilizada para irrigação na bacia do ribeirão dos Marins

12 Localização de pontos de lançamento de esgoto, rede coletora de esgoto, estações elevatórias e hortas referentes ao mapa de uso e cobertura do solo de 2000 na bacia do ribeirão dos Marins

13 Localização das fossas, pontos de lançamento de esgoto e hortas na bacia do ribeirão dos Marins 
14 Localização do aterro sanitário, visualização das hortas levantadas por fotografias aéreas de 2000 e fotografias do aterro sanitário na bacia do ribeirão dos Marins ...........................................................................................

15 Valores das medianas, quartis e extremos da condutividade nos pontos de coleta ao longo do ribeirão dos Marins nas estações seca e cheia

16 Medianas, quartis e valores máximos e mínimos das concentrações de sólidos suspensos totais no ribeirão dos Marins nas estações seca e cheia......

17 Distribuição da saturação de oxigênio dissolvido ao longo do ribeirão dos Marins nas estações seca e chuvosa

18 Localização dos pontos de coleta de água, principais indústrias e empreendimentos e pontos de lançamento de esgoto nos cursos d’água da bacia dos Marins

19 Medianas, quartis e valores máximos e mínimos de coliformes fecais nos pontos de coleta ao longo do ribeirão dos Marins nas estações seca e cheia...

20 Sobreposição dos mosaicos de fotografias aéreas de 1962, 1995 e 2000 com a rede de drenagem da bacia do ribeirão dos Marins.

21 Fotografias aéreas de 1962, 1995 e 2000 mostrando alterações na paisagem da bacia do ribeirão dos Marins

22 Distribuição do uso e cobertura do solo nos setores inicial, central e final da bacia do ribeirão dos Marins.

23 Distribuição das classes de vegetação nos setores inicial, central e final da bacia do ribeirão dos Marins

24 Localização das Áreas de Preservação Permanente na bacia dos Marins.

25 Distribuição das classes do fator topográfico (LS) na bacia do ribeirão dos Marins

26 Mapa do Potencial Natural de Erosão na bacia dos Marins.....

27 Distribuição espacial das classes adaptadas da capacidade de uso na bacia dos Marins

28 Mapas de uso e cobertura do solo da bacia do ribeirão dos Marins referentes aos anos de 1962, 1995 e 2000 .....

29 Distribuição espaço-temporal das classes de uso e cobertura do solo da bacia do ribeirão dos Marins, em 1962, 1995 e 2000 
30 Mapas de vegetação da bacia do ribeirão dos Marins referentes aos anos de

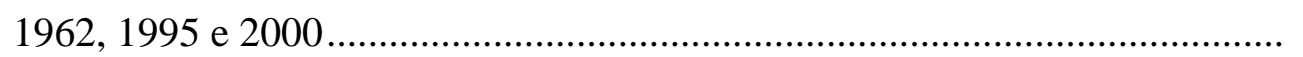

31 Distribuição temporal das classes de vegetação na bacia dos Marins em 1962, 1995 e 2000 ............................................................................... 101

32 Mapas de risco de erosão da bacia do ribeirão dos Marins em 1962, 1995 e

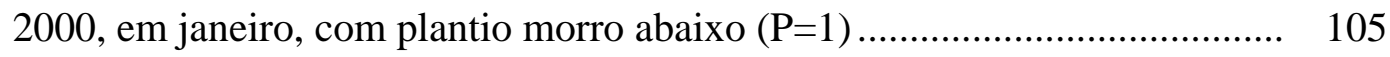

33 Mapas de risco de erosão da bacia do ribeirão dos Marins em 1962, 1995 e 2000, em janeiro, com plantio em contorno $(\mathrm{P}=0,5)$................................... 106

34 Mapa de adequabilidade do uso do solo de 1962, 1995 e 2000 quanto ao risco de erosão na bacia dos Marins............................................................ 109

35 Distribuição espacial da vegetação em 1962, 1995 e 2000 nas Áreas de Preservação Permanente da bacia dos Marins ................................................ 116 


\section{LISTA DE TABELAS}

Página

1 Quadrículas das cartas base (1:10.000) referentes à bacia dos Marins (IGC, 1977,1978 e 1979) ............................................................................... 11

2 Dados de entrada para estimativa das vazões naturais na bacia dos Marins pelo método de regionalização.................................................................... 15

3 Valores de erodibilidade para as unidades de solo da bacia dos Marins ........ 36

4 Valores do fator cultural (C) correspondentes as diferentes classes de uso e cobertura do solo........................................................................ 38

$5 \quad$ Classificação da declividade nas classes de capacidade de uso do solo .......... 40

6 Relação entre o deflúvio e a classe de capacidade de uso do solo................... 41

7 Classes finais da capacidade de uso adaptada para a bacia do ribeirão dos

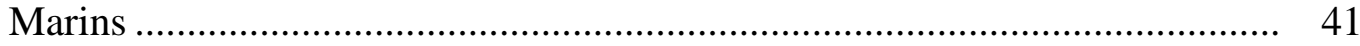

8 Especificações para definição da adequação do uso.................................... 44

9 Valores estimados de vazões pelo método da regionalização no ribeirão dos Marins 47

10 Percentuais das diferentes classes de declividade na bacia dos Marins.......... 47

11 Percentuais das unidades de solo, na escala semi-detalhada, na bacia do ribeirão dos Marins ................................................................................. $\quad 50$

12 População na bacia do ribeirão dos Marins ................................................. 50

13 Estratificação das propriedades do município de Piracicaba .......................... 52

14 Exploração agrícola na bacia do ribeirão dos Marins ..................................... 53

15 Pecuária na bacia do ribeirão dos Marins ................................................... 53

16 Análise das águas superficiais na bacia do ribeirão dos Marins ..................... 66 
17 Impactos ocasionados pelo aterro na bacia do ribeirão dos Marins................ 67

18 Comprimento do ribeirão dos Marins entre os pontos de amostragem ........... 71

19 Erosividade (EI) e precipitação média ao longo do ano ............................... 85

20 Distribuição do risco de erosão em 2000 nos setores que formam a bacia dos Marins, em janeiro considerando plantio morro abaixo $(\mathrm{P}=1)$.................... 88

21 Matriz de transição do percentual da área das classes de uso e cobertura do solo nos dois períodos ....................................................................................... 93

22 Índices de métrica da paisagem da bacia do ribeirão dos Marins nos anos de 1962,1995 e 2000.

23 Índices de métrica das classes de uso e cobertura do solo dos anos de 1962, 1995 e 2000 da bacia do ribeirão dos Marins ................................................ 96

24 Distribuição percentual das áreas de risco de erosão de 1962, 1995 e 2000 na bacia dos Marins

25 Distribuição percentual do uso e cobertura do solo nas classes de risco de erosão, em janeiro considerando plantio morro abaixo ( $\mathrm{P}=1)$, em 1962, 1995 e 2000 na bacia dos Marins.......................................................................... 107

26 Distribuição percentual da área da bacia dos Marins nas classes de adequabilidade do uso do solo quanto ao risco de erosão em 1962, 1995 e 2000 .

27 Distribuição do percentual das classes de adequabilidade do uso do solo quanto ao risco de erosão em 2000 nos setores que formam a bacia dos Marins

28 Uso e cobertura do solo em 1962, 1995 e 2000 nas Áreas de Preservação Permanente ao longo dos cursos d’água na bacia dos Marins

29 Vegetação em 1962, 1995 e 2000 nas Áreas de Preservação Permanente ao longo dos cursos d'água na bacia dos Marins.

30 Distribuição do uso e cobertura do solo em 2000 nas diferentes classes de risco de erosão, em janeiro considerando plantio morro abaixo, nos três setores que formam a bacia dos Marins 


\title{
DIAGNÓSTICO AMBIENTAL E ANÁLISE TEMPORAL DA ADEQUABILIDADE DO USO E COBERTURA DO SOLO NA BACIA DO RIBEIRÃO DOS MARINS, PIRACICABA - SP
}

\author{
Autora: CATIA ANDERSEN CASAGRANDE \\ Orientadora: Profa. Dra. MARIA VICTORIA RAMOS BALLESTER
}

\section{RESUMO}

O diagnóstico ambiental e a análise da adequabilidade da ocupação permitem a identificação de áreas mais críticas quanto ao nível de degradação, sendo extremamente relevantes para o estabelecimento de medidas de preservação, conservação e recuperação. Este trabalho teve como objetivo realizar um diagnóstico ambiental e analisar a adequabilidade do uso e cobertura do solo da bacia hidrográfica do ribeirão dos Marins ao longo do tempo e sua influência sobre os recursos hídricos, considerando a legislação vigente, através de técnicas de geoprocessamento. Foram realizadas as análises das mudanças que ocorreram na bacia, da adequabilidade do uso e cobertura do solo e das relações entre alguns aspectos considerados no trabalho. As análises envolveram aspectos relacionados à qualidade da água, ao uso e cobertura do solo, a estrutura da paisagem, ao risco de erosão, a capacidade do uso do solo e a adequabilidade do uso do solo quanto às limitações devido ao risco de erosão, as condições das Áreas de Preservação Permanente (APPs) e ao Código Florestal. Constatou-se que os recursos hídricos da bacia estão sendo degradados, o uso e 
cobertura do solo está inadequado e um processo de fragmentação está ocorrendo na paisagem. Fontes potenciais de contaminação dos recursos naturais foram identificadas na bacia, comprometendo a qualidade da água utilizada para irrigação de hortaliças. A urbanização é o fator de maior influência na qualidade da água, apesar de predominar na bacia em 1962, 1995 e 2000 a pastagem e a cana-de-açúcar. Um aumento de 6,5 \% da área urbana foi verificado em 38 anos. A classe dos fragmentos florestais também aumentou (4,5 \%), no entanto, esta é menor nas cabeceiras, região mais exposta a ação erosiva. Áreas inadequadas e adequadas com restrições, mais críticas devido o risco de erosão, correspondem mais de $12 \%$ da bacia e estão diminuindo ao longo dos anos. Situações irregulares com relação à legislação e a preservação ambiental foram detectadas na bacia. Na maior parte das APPs ao longo dos cursos d'água o uso e cobertura do solo está inadequado, principalmente por não cumprir a função ambiental determinada pelo Código Florestal, predominando nestas as pastagens. Uma política ambiental eficiente é necessária, considerando um planejamento ambiental adequado que oriente a ocupação da bacia e a adoção de medidas para a recuperação da mesma.

Palavras-chave: bacia dos Marins, geoprocessamento, uso e cobertura do solo, ecologia da paisagem, Área de Preservação Permanente, risco de erosão. 


\title{
ENVIRONMENTAL DIAGNOSTIC AND TEMPORAL ANALYSIS OF THE SUITABILITY OF THE LAND USE AND LAND COVER IN THE “RIBEIRÃO DOS MARINS” BASIN, PIRACICABA - SP
}

\author{
Author: CATIA ANDERSEN CASAGRANDE \\ Adviser: Profa. Dra. MARIA VICTORIA RAMOS BALLESTER
}

\section{SUMMARY}

The environmental diagnostic and the analysis of the occupation suitability allows the identification of more critical areas according to its degradation level, being extremely important for the establishment of preservation, conservation and recovery measures. An environmental diagnostic and suitability analysis of the land use and land cover of the "Ribeirão dos Marins" watershed was carried out, considering the land cover changes through time and its influence on the water resources, in respect to the current environmental legislation, using geoprocessing techniques. Analysis of the changes in the watershed, the suitability of the land use and land cover, and the relation among some aspects considered in this study were performed. The analysis involved aspects related to water quality, land use and land cover, landscape structure, erosion risk, land use capability and suitability of the land use in relation to erosion risk limitations, and environmental legislation, including Permanent Preservation Areas (PPAs). It was observed that the water resources of the basin are being degraded, the land use and land cover is inadequate and landscape fragmentation is underway. 
Potential contamination sources of the watershed's natural resources were identified, compromising the water quality used for horticulture irrigation. Urbanization is the main factor influencing water quality, although pastures and sugar cane predominated in the watershed in 1962, 1995 and 2000. A $6.5 \%$ increase in urban area was verified in the last 38 years. Forest fragments also increased in the basin (4.5\%); however, this increase was less intense in the headwaters, were lower soil protection yields a high erosion risk. Areas classified as suitable with restrictions and unsuitable, more critical due the high erosion risk, corresponds more than $12 \%$ of the basin but are reducing through time. Irregular situations regarding the environmental legislation and preservation were detected in the watershed. Land use and land cover are inadequate in a large extent of the PPAs around of the watercourses, mainly for not attending the environmental functions defined by the Forestry Code. These areas are predominantly covered by pastures. An effective environmental policy is necessary, which must consider suitable environmental planning, guiding the occupation of the basin and the adoption of mitigation measures.

Keywords: Marins watershed, geoprocessing, land use and land cover, landscape ecology, Permanent Preservation Area, erosion risk. 


\section{INTRODUÇÃO}

Nas últimas décadas podemos notar a crescente preocupação com o ambiente, principalmente a partir de 1992, quando foi realizada a Conferência das Nações Unidas sobre Meio Ambiente e Desenvolvimento, no Rio de Janeiro. Com a elaboração da Agenda 21, buscou-se promover o Desenvolvimento Sustentável em todo o mundo, tendo em vista uma interação equilibrada entre as questões econômicas, sociais e ambientais.

Para atingir a sustentabilidade, os municípios começaram a atuar de forma integrada, sob uma visão sistêmica, procurando estabelecer uma política ambiental mais eficiente. Como subsídios a esta política, torna-se de grande importância um diagnóstico ambiental, analisando conjuntamente todos os dados referentes, direta ou indiretamente, ao local de interesse.

A vegetação protege o solo contra erosões, desmoronamentos de encostas e assoreamento dos corpos d'água, ou seja, contribui para a preservação do solo e seus atributos. A preservação da cobertura florestal também traz diversos benefícios aos municípios, dentre eles, promove a conservação da biodiversidade, gera benefícios sociais, possui inimigos naturais contra pragas e doenças no cultivo agrícola, atenua mudanças climáticas e, conseqüentemente, os seus efeitos ajuda a controlar as enchentes, entre outros (Benedito, 2001).

Tendo em vista a necessidade de preservar os recursos naturais, o Código Florestal (Lei Federal 4771 de 15/09/65, alterada pela Lei Federal 7803 de 18/07/89) contém normas que visam a proteção das florestas e demais formas de vegetação, instituindo as áreas de preservação permanente e a reserva florestal legal. Estas têm a função ambiental de preservar os recursos hídricos, a paisagem, a estabilidade geológica, 
a biodiversidade, o fluxo gênico da fauna e da flora, proteger o solo e assegurar o bemestar público.

Para conduzir as explorações agrícolas com bases conservacionistas, sem descuidar dos interesses financeiros dos agricultores, é necessária a planificação racional do uso do solo a ser dado a cada gleba de terra, considerando o conjunto das suas principais características físicas, ecológicas e econômicas (Bertoni \& Lombardi Neto, 1990).

A bacia do ribeirão dos Marins, objeto deste estudo, pertence ao município de Piracicaba e é de grande importância sócio-econômica e ambiental para a região. Os recursos hídricos provenientes desta bacia são utilizados para irrigar grande parte das hortaliças que abastecem o Município e região, dentre outros usos.

Diante dos aspectos apresentados, para o desenvolvimento deste estudo foram definidas as seguintes hipóteses de trabalho: na bacia dos Marins um processo de fragmentação está ocorrendo na paisagem, o uso e cobertura do solo estão inadequados e os recursos hídricos estão degradados. Desta forma, este trabalho teve como objetivos realizar um diagnóstico ambiental e analisar a adequabilidade do uso e cobertura do solo da bacia hidrográfica do Ribeirão dos Marins ao longo do tempo e seu efeito sobre os recursos hídricos, frente à legislação vigente, utilizando técnicas de geoprocessamento.

Este trabalho é de fundamental importância para a compreensão dos padrões de organização do espaço agrícola, o qual está cada vez mais alterado pela ação antrópica. As informações deste trabalho poderão contribuir para o estabelecimento de medidas de preservação, conservação e recuperação da bacia hidrográfica estudada, contribuindo para o estabelecimento de um Planejamento Ambiental e indiretamente para a sustentabilidade. 


\section{REVISÃO DE LITERATURA}

As constantes mudanças no uso e cobertura do solo provocam alterações significativas no balanço de água, com reflexos nas camadas superficiais e subsuperficiais do solo, resultando em erosão, transporte de sedimentos e elementos químicos, bem como causando modificações nos ecossistemas e na qualidade da água (Toledo, 2001).

Com levantamentos do uso e cobertura do solo, os padrões de organização do espaço podem ser compreendidos e podem-se observar as conseqüências do uso inadequado da terra (Rosa, 2001). O uso do solo raramente permanece inalterado. Assim, existe a necessidade de atualização constante dos registros de uso e cobertura do solo, para que suas tendências possam ser analisadas (Loch, 1993).

Uso do solo denota o emprego humano da terra, como por exemplo, cultivos, pastos, recreação, silvicultura etc. Por outro lado, cobertura do solo representa o estado físico do solo, englobando a quantidade e o tipo de vegetação da superfície, água e materiais terrestres (Turner II \& Meyer, 1994). Uma das formas de se obter informações sobre o uso e cobertura do solo é através do mapeamento com sensores aerotransportados e orbitais.

Assim, a fotointerpretação, que consiste na utilização de métodos ou técnicas na análise de imagens e permite a obtenção de informações significativas e confiáveis nos diferentes ramos da ciência da terra, tem como finalidade examinar a imagem de um objeto para identificá-lo e deduzir o seu significado (Rosa, 2001).

A interpretação visual de imagens baseia-se no processo de análise destas pela detecção, identificação e classificação dos alvos de interesse. Na análise da imagem é essencial a percepção de feições pela análise de características fundamentais. Como 
exemplos de alguns elementos de análise de imagens, temos: cor, tonalidade, textura, tamanho, forma, padrão, sombras, altura, localização do alvo e aspectos associados (Vettorazzi, 1992). Nesta técnica, a identificação de objetos apoia-se no "princípio de convergência de evidências”, que aponta sua provável identidade. As evidências indicam a identidade de um objeto baseada nos elementos de reconhecimento (Toledo, 2001).

As fotografias aéreas possuem um recobrimento longitudinal de $60 \%$ e lateral de 30\%. Este fato proporciona a visão estereoscópica, ou seja, a observação em três dimensões de duas fotos aéreas consecutivas com o auxílio de aparelhos especiais chamados estereoscópios (Rosa, 2001). Essas fotografias permitem pela análise das características do terreno a elaboração de mapas temáticos, como de uso e cobertura do solo. Através destes podem ser realizadas análises com os elementos da paisagem identificados.

Os elementos da paisagem influenciam de forma expressiva os processos ecológicos (Turner et al., 2001). Muita ênfase tem sido dada ao desenvolvimento de métodos para quantificar a estrutura da paisagem. A habilidade em quantificar esta estrutura é um pré-requisito para o estudo das mudanças estruturais e funcionais dos ecossistemas (McGarigal, 1997). Assim, a ecologia da paisagem estuda o efeito do padrão da paisagem nos processos ecológicos (Turner, 1989). Para tal, diversos índices, também conhecidos como métricas da paisagem, foram desenvolvidos de modo a descrever quantitativamente a composição e configuração espacial de uma paisagem. Essas variáveis, as quais permitem uma caracterização geométrica e espacial das propriedades da paisagem, têm sido utilizadas para relacionar aspectos do padrão encontrado nesta com os processos ecológicos e ambientais (Gergel \&Turner, 2002; McGarigal, 2002; Frohn, 1998; Turner et al., 2001).

Para calcular a ampla variedade de métricas existentes uma série de programas já foram elaborados, como por exemplo o FRAGSTATS, desenvolvido para análise da estatística espacial, e a extensão V-LATE do programa ArcGIS 9, para análise da paisagem. Os índices podem ser calculados para cada fragmento na paisagem, para as classes de uso do solo e para a paisagem como um todo. Nos níveis de classe e paisagem, algumas métricas quantificam a composição, representam a variedade e abundância de 
fragmentos. Outras quantificam a configuração, a qual está relacionada à forma e posição dos mesmos em relação à paisagem (McGarigal \& Marks, 1995; McGarigal, 2002).

Estes índices de métrica, indicam a fragmentação de uma paisagem, permitem a caracterização e a diferenciação de aspectos espaciais da estrutura da mesma ao longo do tempo (Forman, 1997; Turner \& Gardner, 1990; McGarigal \& Marks, 1995; Turner et al., 2001). Estas informações auxiliam na realização do diagnóstico da área de estudo, o qual fornece subsídios para um planejamento adequado que pode ser introduzido como um instrumento fundamental para alcançar o desenvolvimento sustentável. O conceito deste, definido pela Comissão Mundial de Desenvolvimento e Meio Ambiente em 1987, consiste em “... Atender às necessidades da geração presente sem comprometer a habilidade das gerações futuras de atenderem suas próprias necessidades ...” (Braga et al., 2002). Assim, com um planejamento ambiental, respeitando as limitações apresentadas pelo meio físico à implantação das atividades humanas, é possível conciliar crescimento econômico e preservação ambiental, na tentativa de atingir o chamado “desenvolvimento sustentável” (Guerra et al., 1999).

A ocorrência de impactos ambientais decorrentes da ação antrópica indiscriminada pode ser minimizada em função de um planejamento adequado. A orientação da ocupação humana é necessária para resguardar as áreas destinadas à preservação ambiental, tendo em vista a conservação dos recursos naturais, a forte instabilidade ou fragilidade ambientais e a alta suscetibilidade à erosão e movimentos de massa que certas porções da paisagem podem apresentar (Guerra et al., 1999).

O Planejamento Ambiental pode ser entendido como um processo, com desenvolvimento de técnicas, elaborado como um sistema estruturado que envolve etapas distintas, identificando os objetivos e criando procedimentos e programas para atingi-los, visando a melhoria da qualidade de vida em uma escala espacial e temporal, conciliando desenvolvimento e qualidade ambiental (Santos et al., 1997; Oliveira, D. 1999; Silva, 2001; Cabo et al., 1997; Branco \& Rocha, 1980; Lima-e-Silva et al., 1999).

Em microbacias hidrográficas o planejamento ambiental exige, em função da escala de trabalho, um levantamento intenso de dados sobre a distribuição e 
comportamento das variáveis de análise selecionadas. A delimitação de unidades ambientais resultantes da integração de diferentes fatores ou elementos do meio físico revela-se extremamente útil ao processo de planejamento. Isso permite expressar a complexidade existente na paisagem e garante um nível de detalhamento equilibrado entre as variáveis físicas adotadas (Guerra et al., 1999).

As condições físicas da bacia hidrográfica, alterações antrópicas na paisagem e a qualidade e quantidade da vegetação ripária, influenciam a comunidade biológica dos rios. Muitas atividades intensivas de uso do solo têm reduzido a capacidade de armazenamento de água do solo e restringido, drasticamente, os níveis de água. Assim, o gerenciamento da terra deve ocorrer sob a perspectiva da paisagem, a qual permite um entendimento da integração completa dos processos que operam através de um corpo d'água e que interferem nos processos biológicos (Liu, 2002).

Para a implementação de diversos projetos, o planejamento ambiental considera a importância do estudo e a avaliação prévia do meio ambiente. Assim, a postura preventiva revela-se menos onerosa e mais eficiente no combate à ocorrência de impactos ambientais, como a erosão dos solos (Guerra et al., 1999; Braga et al., 2002). Quando este conceito não é aplicado, as atividades antrópicas podem causar danos aos recursos naturais devido ao lançamento de efluentes, uso incorreto do solo favorecendo a erosão, dentre outras práticas inadequadas que podem causar impactos nos diferentes ecossistemas, inclusive nos corpos d'água.

A qualidade da água de mananciais que compõem uma bacia hidrográfica está relacionada com o uso do solo na bacia e com o grau de controle sobre as fontes de poluição (Silva et al., 2003). A influência antrópica na qualidade da água inclui alterações na concentração de substâncias químicas encontradas naturalmente, a entrada de novas substâncias sintéticas e mudanças nos sedimentos carregados. De modo geral, a fonte de poluição pode ser dividida em não pontual (difusa) e pontual (Morris \& Therivel, 2001). Fontes pontuais, como o lançamento de efluentes industriais e domésticos, podem ser identificadas mais facilmente. No entanto, geralmente é mais difícil identificar e estimar as entradas resultantes de fontes difusas, como acréscimos de 
nutrientes e agrotóxicos advindos da atividade agrícola (Newson, 1997; Carpenter et al., 1998; Sliva \& Williams, 2001).

A poluição de origem agrícola causa modificações na composição química e biológica das águas. Um dos problemas desencadeado nos sistemas aquáticos pela entrada excessiva de nitrogênio e fósforo é a eutrofização. Além disso, com o aporte de nutrientes ou contaminantes que acompanham os fertilizantes agrícolas, estes podem afetar diretamente a saúde da população que se abastece dos recursos hídricos (Martini \& Lanna, 2003; Carpenter et al., 1998).

A ocupação urbana também pode degradar severamente os sistemas aquáticos. Além dos efeitos de fontes pontuais como dos efluentes domésticos e industriais, o escoamento superficial urbano constitui uma fonte não pontual relevante. Esta água contém poluentes que podem alterar as características físico-químicas da água e prejudicar a comunidade biológica dos corpos d’água. Uma quantidade significativa de fósforo e nitrogênio é introduzida nas águas superficiais através de fontes urbanas difusas, podendo favorecer o processo de eutrofização (Walsh et al., 2001; Carpenter et al., 1998; Wang et al., 2001).

A presença de vegetação na região ribeirinha constitui um fator importante para a mitigação da degradação da água, pois ela contribui para a redução dos efeitos da erosão, diminuindo a entrada de sedimentos e poluentes nos corpos d’água. A zona ripária funciona como um "filtro" da água advinda do escoamento superficial (Sliva \& Williams, 2001; Wang et al., 2001; Simões et al., 2002). Um dos parâmetros físicos da água mais afetados pelo aporte de sedimentos aos cursos d’água é a turbidez. Águas com alta turbidez afetam a entrada de luz na coluna d’água. Não havendo entrada de luz, diminui a taxa de produção primária do ecossistema, afetando toda cadeia alimentar, inclusive com alterações nos padrões de produção e consumo de gases (Silva et al., 2003).

Com a deflagração dos processos erosivos, em função da ocupação do solo, as perdas de solo por erosão laminar são comandadas por diversos fatores relacionados às condições naturais dos terrenos. Em bacias hidrográficas degradadas, áreas de cabeceiras estão com freqüência desprovidas de vegetação natural e apresentam sinais de 
degradação pela erosão e indícios da instabilidade intrínseca dessas áreas. Estas são caracterizadas como de risco a eventos erosivos, pois são fontes geradoras de fluxo (Guerra et al., 1999).

A utilização do solo acima da capacidade, o uso e o manejo inadequado do solo, acelera o processo de erosão. A degradação do solo pode ser acelerada por diversos fatores, como pela alta densidade de gado, a qual conduz para a degradação da vegetação e altera a compactação do solo. (Gobin et al., 2003). A ocupação mais intensa de terrenos próximos às ocorrências erosivas multiplica os riscos de acidentes. Junto com os riscos de acidentes, geralmente as ravinas e voçorocas se tornam áreas de despejo de lixo, às vezes até como tentativa desastrosa de contenção. O lixo e os lançamentos de esgoto transformam a erosão em focos de doenças, tornando-a ainda mais danosa ao ambiente (Guerra et al., 1999).

Uma característica típica das áreas de ocupação urbano-industrial é a intensa movimentação de terra nas áreas ocupadas, que vão desde o nível dos assentamentos de lotes residenciais até a implantação de grandes obras públicas ou privadas. Alterações significativas na topografia, para permitir o assentamento da obra e a necessidade de cortes profundos e aterros de compensação, podem deixar expostos às ações erosivas substratos frágeis (Silva et al., 2003).

O controle da erosão em áreas rurais é muito complexo, por envolver questões tanto de ordem técnica como sócio-econômica, que devem ser conjuntamente avaliadas, visando à adoção de uma política agrícola que contemple a manutenção ou aumento do potencial produtivo das terras. No que se refere às questões técnicas, destacam-se como fundamentais: a utilização adequada de práticas agrícolas de conservação do solo, a adoção de medidas preventivas contra a erosão associada a estradas e fornecimento de subsídios visando o planejamento da ocupação agrícola, considerando a capacidade de uso das terras (Guerra et al., 1999). 


\section{MATERIAL E MÉTODOS}

\subsection{Descrição da área de estudo}

A bacia de drenagem do ribeirão dos Marins, afluente do rio Piracicaba por sua margem esquerda, está localizada inteiramente no município de Piracicaba entre as coordenadas UTM 7.471.450 m e 7.486.995 m N e 218.044 m e 225.545 m E, com uma área de 58,44 km² (Figura 1). Considerando o perímetro urbano obtido do IBGE (2002a), 14,5\% da área da bacia está na zona urbana.

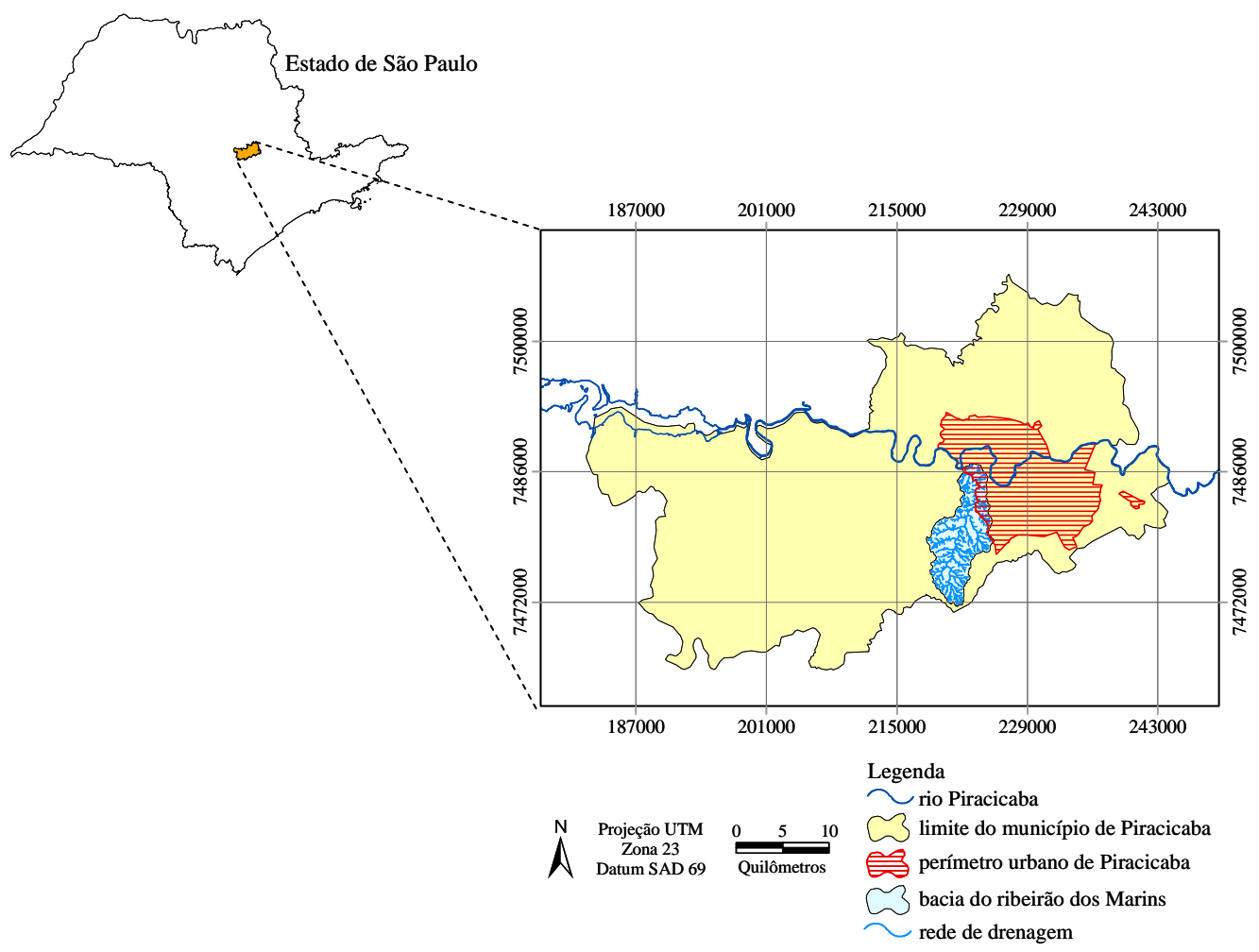

Figura 1 - Localização da área de estudo, bacia do ribeirão dos Marins 
O clima da região, segundo a classificação de Koeppen, é do tipo mesotérmico, Cwa, isto é, subtropical úmido com estiagem no inverno. As chuvas do mês mais seco não atingem $30 \mathrm{~mm}$ e a temperatura do mês mais quente é superior a $22^{\circ} \mathrm{C}$, enquanto a do mês mais frio é inferior a $18^{\circ} \mathrm{C}$. A precipitação média anual é de aproximadamente $1.300 \mathrm{~mm}$. Cerca de $70 \%$ do volume de precipitação ocorre no verão, situação característica de clima tropical. Em termos geomorfológicos, a bacia está localizada em terrenos sedimentares que formam a Depressão Periférica.

A bacia dos Marins tem aproximadamente 8009 habitantes e é composta por 19 bairros, os quais estão distribuídos ao longo de toda bacia. Ela funciona como um cinturão verde para o município de Piracicaba e região. Nesta área predominam a cultura da cana-de-açúcar e a pastagem, utilizada em sua maioria pela pecuária mista, explorações estas que prevalecem já há algumas décadas. As culturas de cereais, em pequena escala, e a da cana-de-açúcar fazem com que as áreas sejam perturbadas com preparação de terra durante o ano, deixando o solo bastante susceptível ao processo erosivo (CATI, 2001).

\subsection{Elaboração do banco de dados}

Os planos de informação do banco de dados digital georreferenciado foram elaborados, processados e analisados utilizando-se os seguintes Sistemas de Informações Geográficas:

- Arc-Info 7.3.1 para estação de trabalho;

- ArcGIS 9.0, 8.3 e 8.1 e ArcView 8 para computadores pessoais;

- Erdas Imagine 8.6.

Os planos de informação foram georreferenciados e projetados no sistema de coordenadas Universal Transverso de Mercator (UTM), zona 23, elipsóide SAD-69 (South American - 1969), datum SAD-69, origem Equador, 45 W (10.000 km / 500 km). Esta projeção é do tipo cilíndrica conforme, permitindo representar corretamente áreas e distâncias. 
A base cartográfica do banco de dados foi constituída pelas cartas base do Instituto Geográfico e Cartográfico do Estado de São Paulo (IGC) na escala 1:10.000. Para cobrir a área de estudo foram utilizadas as quadrículas apresentadas na Tabela 1.

Tabela 1. Quadrículas das cartas base (1:10.000) referentes à bacia dos Marins (IGC, 1977, 1978 e 1979)

\begin{tabular}{lcc}
\hline Folha & Nomenclatura & Ano \\
\hline Santa Terezinha do Piracicaba & SF-23-Y-A-IV-2-S0-C & 1979 \\
Piracicaba V & SF-23-Y-A-IV-2-S0-D & 1979 \\
Bairro dos Marins & SF-23-Y-A-IV-2-S0-E & 1979 \\
Piracicaba III & SF-23-Y-A-IV-2-S0-F & 1979 \\
Bairro Volta Grande & SF-23-Y-A-IV-4-N0-A & 1978 \\
Piracicaba II & SF-23-Y-A-IV-4-N0-B & 1978 \\
Sete barrocas & SF-23-Y-A-IV-4-N0-C & 1978 \\
Mato Alto & SF-23-Y-A-IV-4-N0-E & 1977 \\
\hline
\end{tabular}

Destes mapas, foram extraídos os temas referentes à:

- topografia: linhas cotadas eqüidistantes 5 metros.

- rede de drenagem: rios, córregos, lagos e represas.

- malha viária: rodovias e estradas.

As cartas foram convertidas para o formato digital através de digitalização manual, utilizando uma mesa digitalizadora Calcomp 9500. Uma vez no formato digital, as quadrículas foram unidas, inspecionadas visualmente e corrigidas as inconsistências relativas ao posicionamento e atributos.

\subsection{Diagnóstico ambiental}

Para o diagnóstico ambiental foram levantadas informações referentes aos aspectos físicos, antrópicos e bióticos. Um banco de dados foi constituído por planos de informações georreferenciados e por dados da literatura, obtidos em estudos já realizados e de órgãos competentes. Os dados obtidos e elaborados referem-se, 
basicamente, as características dimensionais da bacia e rede de drenagem, vazão e precipitação, topografia, população, situação fundiária, agricultura e pecuária, produtores de hortaliças, outorgas, indústrias e empreendimentos, qualidade da água, geologia e geomorfologia, pedologia, uso e cobertura do solo, cobertura florestal, áreas de preservação permanente, erosão, capacidade de uso do solo, dentre outros.

O diagnóstico foi elaborado com dados de diferentes datas em função da não disponibilidade de informações de um mesmo ano para todas características levantadas. Para melhor representar as mudanças que estão ocorrendo na área de estudo, algumas informações foram obtidas também para outros anos, com o intuito de mostrar o histórico da região. Quanto ao uso e cobertura do solo, fotografias aéreas de 1962, 1995 e 2000 foram consideradas como base para a realização da análise temporal. Estes dados, referente ao diagnóstico ambiental, foram levantados e processados de acordo com metodologia descrita a seguir.

\section{Características dimensionais da bacia e da rede de drenagem}

A bacia hidrográfica foi delimitada com base nas fotografias aéreas com o auxílio de um estereoscópio e a rede de drenagem derivada das cartas base do IGC (1977, 1978 e 1979). As características da bacia e da rede de drenagem determinadas foram:

- Maior comprimento (C): medido com o escalímetro do programa ArcGIS, é a distância que acompanha aproximadamente o vale principal, entre a foz e o ponto extremo sobre a linha do divisor de água. Os resultados são expressos em quilômetros;

- Maior largura (L): medido com o escalímetro do programa ArcGIS, é a distância correspondente à maior largura que corta transversalmente o vale principal. Os resultados são expressos em quilômetros;

- Comprimento do curso d'água principal (Cp): obtido da somatória dos segmentos correspondentes ao canal principal, ou seja, o comprimento do curso principal da nascente ao exutório. Os resultados são expressos em quilômetros;

- Comprimento total da rede (Cr): obtido da somatória dos segmentos correspondentes ao canal principal e tributários. Os resultados são expressos em quilômetros; 
- Perímetro da bacia $(P)$ : representado pela linha do divisor de águas que circunda a bacia. Os resultados são expressos em quilômetros;

- Área da bacia (A): compreende a área delimitada pela linha do divisor de águas. Os resultados são expressos em quilômetros quadrados;

- Densidade de drenagem (Dd): relação entre o comprimento total dos rios da bacia (Cr) dado em quilômetros e a respectiva área em quilômetros quadrados.

\section{Dados Pluviométricos e Fluviométricos}

As informações referentes aos postos pluviométricos e fluviométrico foram levantadas junto ao Centro Tecnológico de Hidráulica - CTH/DAEE. A Figura 2 apresenta a localização dos únicos postos pluviométricos (6) existentes na sub-bacia “Monjolinho" do ribeirão dos Marins. Atualmente estes postos estão desativados devido à falta de manutenção e recursos do órgão competente. Porém, informações continuam sendo levantadas pelos interessados junto aos proprietários onde estão instalados os postos.

Os dados referentes ao posto de medição da vazão necessitam de correções, pois existem falhas e diferenças de horário entre as leituras das escalas limnimétricas de três pontos que são utilizados para o cálculo da vazão. Desta forma, optou-se por apresentar os dados já corrigidos de vazão referentes a 1999 e 2000 (Moretti, 2001), os quais nos fornecem uma caracterização da vazão.

A partir do "Estudo de Regionalização Hidrológica do Estado de São Paulo" (http://www.daee.sp.gov.br/hidrometeorologia/bancodados.htm) foram levantadas informações referentes às vazões naturais nos pontos finais da sub-bacia Monjolinho e da bacia do ribeirão dos Marins (Figura 2). Este estudo de regionalização de variáveis hidrológicas foi desenvolvido pelo DAEE (Departamento de Águas e Energia Elétrica) e se baseou nos totais anuais precipitados em 444 postos pluviométricos do estado de São Paulo. Assim foi elaborada uma carta de isoietas médias anuais, bem como séries de descargas mensais (219 estações) e séries históricas de vazões diárias (88 postos). A análise conjunta dos parâmetros estudados para a obtenção dessas variáveis hidrológicas 
possibilitou identificar 21 regiões hidrologicamente homogêneas e assim, estimar algumas variáveis hidrológicas (DAEE, 1994).

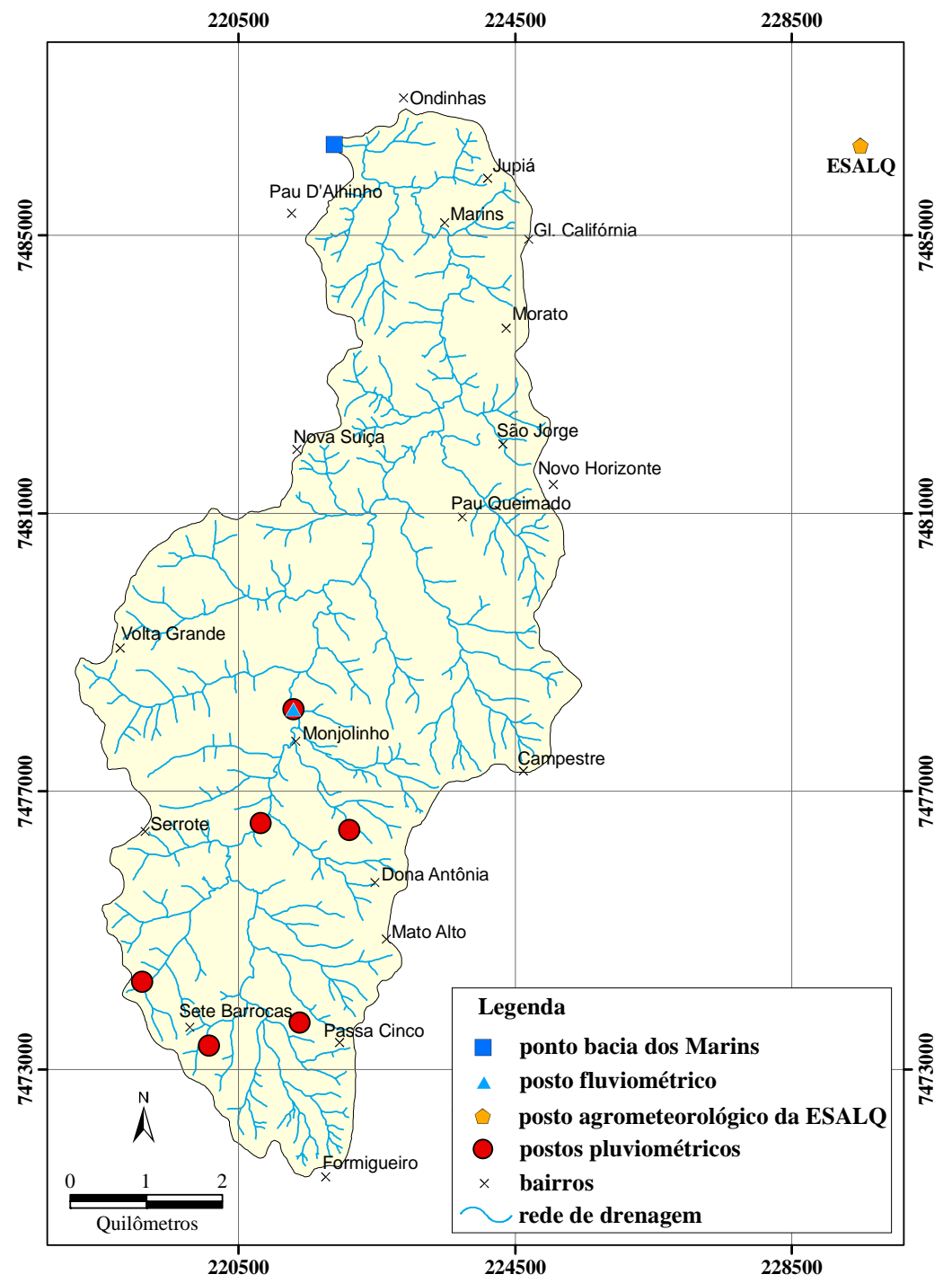

Figura 2 - Localização dos postos pluviométricos, vertedor e ponto final da bacia dos Marins utilizados para a estimativa das vazões naturais

Com base nessa metodologia de regionalização, a precipitação anual média, a vazão específica média plurianual ( $\bar{Q}$ esp ), a vazão média $(\bar{Q})$, a vazão mínima anual de sete dias consecutivos com 10 anos de período de retorno $\left(Q_{7,10}\right)$ e a vazão média com 
95\% de permanência do tempo $\left(Q_{95 \%}\right)$ foram estimadas para duas seções da bacia dos Marins com os dados de entrada apresentados na Tabela 2.

Tabela 2. Dados de entrada para estimativa das vazões naturais na bacia dos Marins pelo método de regionalização

\begin{tabular}{lcc}
\hline & $\begin{array}{c}\text { Sub-bacia Monjolinho } \\
\text { (Moretti, 2001) }\end{array}$ & Bacia dos Marins \\
\hline Área da bacia hidrográfica $\left(\mathrm{km}^{2}\right)$ & 21,85 & 58,44 \\
Longitude do Meridiano Central & 45 & 45 \\
Coordenada UTM Norte (m) & 7478240,49 & 7486360,95 \\
Coordenada UTM Leste (m) & 221496,62 & 221886,51 \\
\hline
\end{tabular}

Quanto aos dados pluviométricos, existem falhas e a série histórica é muito pequena, sendo o período coincidente para os seis postos apenas de janeiro de 1999 a agosto de 2002. Uma vez que o objetivo deste trabalho é utilizar estes dados para calcular a erosividade da chuva, foi realizada uma comparação entre estes e os do posto Agrometeorológico da Escola Superior de Agricultura "Luiz de Queiroz" (ESALQ) em Piracicaba, distante quase $5 \mathrm{~km}$ da bacia (Figura 2), o qual possui uma série histórica desde 1917. Uma diferença de aproximadamente 3 \% foi encontrada na comparação realizada do valor do fator de erosividade da chuva, calculado a partir dos dados de 1999 a 2002. A pequena variação existente entre os dados não foi considerada significativa para o objetivo deste trabalho, sendo que para o cálculo da erosividade somente a média mensal e anual da precipitação são utilizadas. Por não se tratar de precipitações diárias, as variações regionais não são significativas. Desse modo, optou-se por utilizar neste trabalho os dados pluviométricos da ESALQ, para uma caracterização geral e para calcular o fator erosividade da Equação Universal de Perda de Solo.

\section{Topografia}

O Modelo Digital de Elevação do Terreno (MDET) é uma representação matemática de uma característica da superfície terrestre. Ele é um dos planos de 
informação necessário para o cálculo da declividade e da direção de fluxo, sendo essencial para gerar o mapa referente ao fator topográfico da Equação Universal de Perda de Solo. Para gerar um MDET, vários métodos podem ser utilizados. Algorítmos como a Rede Triangular Irregular (RTI), o inverso da potência da distância, a curvatura mínima, a regressão linear e Kriging estão entre os mais usados.

Segundo Fujihara (2002), o método de triangulação irregular (RTI) é o que melhor representa as isolinhas intermediárias entre as cotas originais em uma microbacia no estado de São Paulo quando comparado com métodos de interpolação do Inverso da potência da distância, linear e "Spline". Os quatro modelos não se diferenciam quando analisados pelos critérios de altitude mínima, máxima e média. Porém, comparando as isolinhas extraídas dos modelos e a distribuição das classes de declive geradas, os modelos gerados pelo interpolador Inverso da potência da distância e o linear apresentaram os piores resultados. Baixa correspondência com as cotas originais e a existência de áreas significativas com declividade 0\%, mesmo utilizando uma alta densidade de pontos de amostragem foram observadas. Nesses critérios, os resultados dos modelos de RTI e Curvatura Mínima foram semelhantes. Mas, analisando visualmente, verifica-se que a RTI representou melhor as isolinhas intermediárias entre as cotas originais.

Para escolher a metodologia mais adequada para gerar o Modelo Digital de Elevação do Terreno (MDET) neste trabalho, os aspectos apresentados acima referente aos interpoladores foram considerados. Desse modo, o MDET apresentado neste trabalho foi gerado a partir de curvas de nível obtidas a partir das cartas topográficas digitais, as quais foram interpoladas pelo método de rede de triangulação irregular, de modo a gerar uma rede de altitude com resolução de 5 metros. O modelo digital de elevação do terreno (MDET) foi obtido pela conversão dessa rede para o formato em grade.

Geralmente, os erros que ocorrem em um MDET são classificados como sumidouros ou picos. Um sumidouro é uma área rodeada por valores de elevações maiores, formando áreas de drenagem interna. Alguns destes sumidouros podem ser naturais mas, em geral, são resultado de imperfeições no MDET. De modo semelhante, 
um pico é uma célula rodeada por áreas de elevações inferiores. Estes tipos de erros precisam ser removidos antes do início de qualquer análise da superfície. Os sumidouros/picos foram identificados e removidos através de uma análise feita com a extensão de hidrologia do ArcGIS, a qual verifica a consistência do valor de altitude de cada célula em relação aos seus oito vizinhos e, no caso de não estar correto (sumidouro ou pico), substitui o valor desta célula pela média do valor dos oito vizinhos.

A partir deste MDET corrigido, foi derivado o plano de informação referente à declividade, expressa em porcentagem, e agrupada nas seguintes classes: 0 a 3; 3 a 6; 6 a 12; 12 a 20; 20 a 40 e maior que $40 \%$.

A bacia dos Marins também foi subdividida em sub-bacias com o auxílio da extensão de hidrologia do ArcGIS, do MDET e dos mapas de direção e acúmulo de fluxo gerados a partir destes. As sub-bacias foram delimitadas considerando o limite da bacia dos Marins determinado a partir das fotografias aéreas e de acordo com os limites gerados pela extensão de hidrologia para sete pontos de coleta ao longo do ribeirão dos Marins, os quais foram utilizados para a realização de análises da água pelo projeto da SEMA (Secretaria de Agricultura e Abastecimento de Piracicaba), conforme será mencionado posteriormente.

Para realizar algumas análises neste trabalho, os setores que compõem as sete sub-bacias foram reagrupados em três setores (Inicial, Central e Final), facilitando a análise realizada das cabeceiras e do trecho da bacia mais próximo à urbanização. $\mathrm{O}$ setor considerado inicial corresponde aos setores 1 e 2 , o central aos setores 3 e 4 e o final aos setores 5, 6 e 7 .

\section{População}

A população da bacia do ribeirão dos Marins foi estimada para os anos de 1991 e 2000. Estes anos foram adotados para a análise devido à disponibilidade de informações, sendo a população estimada com base nos dados por setores censitários dos Censos Demográficos obtidos junto ao Instituto Brasileiro de Geografia e Estatística (IBGE) em Piracicaba. Como muitos setores ultrapassaram o limite da bacia, uma proporção entre o número de habitantes e a área foi utilizada para estimar o número 
apenas da parte do setor que está dentro do limite da área de estudo. Para isso, a distribuição da população na área de cada setor foi considerada uniforme.

Para o cálculo da população de 2000, os setores urbanos foram obtidos através do Sistema de Recuperação de Informações Georreferenciadas - ESTATCART (IBGE, 2002b) e da Base de Informações por Setor Censitário (IBGE, 2002a). Os setores da zona rural foram derivados de um mapa de 2000 na escala 1:50.000 (IBGE), o qual foi digitalizado manualmente. Para o cálculo de 1991, os limites dos setores censitários foram levantados junto ao setor do IBGE de Piracicaba e recuperados através da junção dos setores do mapa de 2000, cujos limites são resultantes do fracionamento dos setores censitários de anos anteriores (1991), devido ao aumento do número de residências. Com base nesses dados também foi possível calcular a densidade populacional por setor censitário para ambos os anos e para a bacia em estudo de uma forma geral.

\section{Dados auxiliares}

Um levantamento de dados foi realizado em órgãos municipais e estaduais, obtendo outras informações, além das já especificadas, relevantes para a formação do banco de dados.

Como os bairros do município de Piracicaba não têm seus limites definidos, os nomes destes foram levantados com base em mapas da Secretaria de Planejamento de Piracicaba e do setor de Piracicaba do Instituto Brasileiro de Geografia e Estatística IBGE.

Informações referentes às propriedades, agricultura e pecuária foram obtidas de um projeto que está sendo executado pela Secretaria de Agricultura e Abastecimento do Governo do Estado de São Paulo (SAA), através da Coordenadoria de Assistência Técnica Integral (CATI). A área de estudo deste projeto refere-se à bacia dos Marins, a qual faz parte do Programa Estadual de Microbacias Hidrográficas (CATI, 2001).

Dados referentes aos produtores de hortaliças foram levantados a partir de um projeto da Secretaria de Agricultura e Abastecimento de Piracicaba (SEMA), através de um convênio de cooperação técnica com o Centro de Energia Nuclear na Agricultura (CENA), a Fundação de Estudos Agrários “Luiz de Queiroz” (FEALQ) e o Serviço 
Municipal de Água e Esgoto (SEMAE). O projeto de pesquisa "Bacia Hidrográfica do Ribeirão dos Marins: Levantamento da Qualidade e Quantidade de Água e Potencial para a Implantação do Programa de Produção de Alimentos e de Recuperação Ambiental” foi finalizado em dezembro de 2003 (SEMA, 2003).

No Departamento de Águas e Energia Elétrica (DAEE) foram obtidas informações referentes às outorgas existentes na bacia. No SEMAE foram levantados dados referentes à situação da coleta de esgoto na bacia, a rede de esgoto e a duas estações elevatórias que estão sendo construídas para desviar o esgoto que é lançado no ribeirão dos Marins. A localização de 62 pontos de fossas e de 4 de lançamento de esgoto no ribeirão foi obtida do trabalho do Ruffolo (2003).

As principais indústrias e empreendimentos existentes na bacia foram identificadas com base nos projetos que estão sendo realizados e em visita de campo. Posteriormente, informações a respeito dos empreendimentos que constituem possíveis fontes de poluição foram levantadas nos processos existentes destes na CETESB (Companhia de Tecnologia de Saneamento Ambiental).

Uma pequena caracterização da geologia da região da bacia dos Marins foi obtida do trabalho de Teramoto (1995). Este realizou um estudo das inter-relações existentes entre aspectos pedológicos, geológicos e geomorfológicos de um segmento representativo da microbacia do ribeirão dos Marins, aproximadamente 465,7 ha ou 8\% da área da bacia (Teramoto et al., 2001).

\section{Qualidade da água}

A qualidade da água foi levantada com base nos resultados de análises realizadas em 2002 e 2003, pelo projeto da SEMA (Secretaria de Agricultura e Abastecimento de Piracicaba), em sete pontos de amostragem ao longo do ribeirão dos Marins, a partir dos quais a bacia pode ser dividida em sete setores, conforme Figura 3. Nesta, pode-se visualizar também os pontos referentes às hortas levantadas pelo projeto da SEMA, os quais localizam-se principalmente no trecho mais próximo ao perímetro urbano e aos pontos de coleta 4 e 5. 


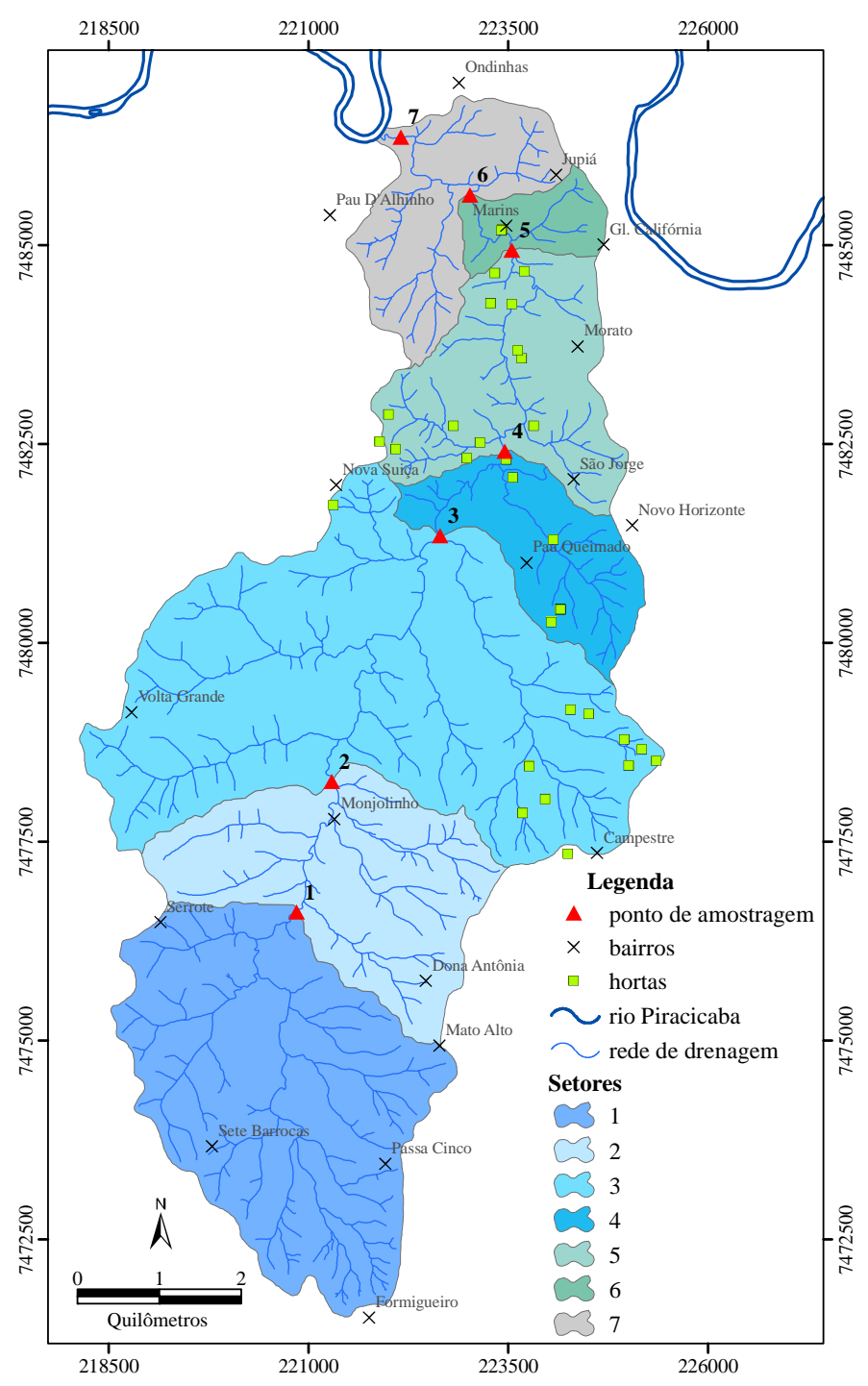

Figura 3 - Localização dos pontos de coleta e setores da bacia do ribeirão dos Marins

As amostragens foram realizadas no período de fevereiro de 2002 a janeiro de 2003 quinzenalmente, a partir desse período, mensalmente até novembro de 2003 (SEMA, 2003). As análises dos parâmetros físicos, químicos e biológicos foram realizadas no campo e em laboratórios do SEMAE (Serviço Municipal de Água e Esgoto).

Neste trabalho foram considerados os seguintes parâmetros: condutividade elétrica, Sólidos Suspensos Totais (SST), Oxigênio Dissolvido (OD) e coliformes fecais. 
Diante da disponibilidade de dados e abordagem deste trabalho, optou-se por utilizar apenas estes parâmetros na análise, os quais possibilitam descrever de forma satisfatória a qualidade da água para o objetivo deste trabalho. As análises destes foram realizadas conforme os métodos descritos pelas Normas da CETESB (L5.115, L5.149, L5.169 e L5.202). Como a temperatura afeta a solubilidade do oxigênio, os valores do oxigênio dissolvido determinados em $\mathrm{mg} \mathrm{L}^{-1}$ foram convertidos para porcentagem de saturação de oxigênio, de acordo com as temperaturas levantadas durante a coleta e os valores da solubilidade de oxigênio na água nestas de acordo com Wetzel (1975).

Os dados de 2002 e 2003 dos diferentes parâmetros mencionados para os diferentes pontos de coleta foram comparados. Ao realizar no programa STATISTICA 5.0 e 6.0 os testes Mann-Whitney U Test e Kruskal-Wallis ANOVA constatou-se que os dados de 2002 e 2003 não apresentam diferença estatística significativa (p>0,05).

O teste Shapiro-Wilk $W$ test foi utilizado para testar a normalidade. De acordo com os resultados obtidos, constatou-se que a condutividade, sólidos suspensos totais, coliformes fecais e saturação de oxigênio não apresentam uma distribuição normal $(\mathrm{p}<0,05)$. Devido estes resultados e pelo fato dos dados serem considerados dependentes, por serem de diferentes pontos de amostragem no mesmo ribeirão, a mediana foi calculada para a elaboração de gráficos para a análise e foram utilizados testes estatísticos não paramétricos.

Com base na vazão média de 1999 e 2000 (Moretti, 2001), agrupou-se os dados em período seco (abril a novembro) e chuvoso (dezembro a março). Os dados de cada parâmetro dos períodos considerados foram comparados no programa STATISTICA 6.0 através do teste Mann-Whitney U Test. Os períodos seca e cheia apresentaram diferenças estatísticas significativas para todos os parâmetros $(\mathrm{p}<0,05)$.

\section{Pedologia}

A carta semi-detalhada dos solos, foi obtida do banco de dados georreferenciado do Projeto Piracena (www.cena.usp.br), na escala 1:100.000, quadrícula de Piracicaba. 


\section{Uso e cobertura do solo}

Os mapas de uso e cobertura do solo foram obtidos do banco de dados do laboratório de Geoprocessamento do CENA (Centro de Energia Nuclear na Agricultura). Para derivar os mapas de uso e cobertura do solo, foram utilizadas fotografias aéreas provenientes do acervo da empresa BASE SA correspondentes aos anos de 1962 e 1995 (escala 1:25.000) e de 2000 (escala 1:30.000). Estes anos foram selecionados para a elaboração destes mapas devido à disponibilidade das fotografias no laboratório, possibilidade de aquisição das fotos dos referidos anos para toda a área de estudo e por representarem um período no qual ocorreram grandes mudanças na paisagem.

A interpretação destas fotografias foi realizada com o auxílio de um estereoscópio de espelho Leica ST4. Para desenhar manualmente o contorno dos polígonos referentes aos diversos componentes que recobrem o solo, foi utilizada folha poliéster sobre as fotografias. Cada polígono foi identificado seguindo a legenda com as seguintes classes: pasto, cana-de-açúcar, fragmento florestal, floresta plantada, cultura anual, cultura perene, urbanização, represas ou reservatórios e horticultura.

Na classificação foi utilizada a metodologia proposta por Koffler et al. (1979), que elaboraram uma chave de interpretação para as seguintes categorias: cana-de-açúcar, pasto, mata, reflorestamento, culturas anuais e culturas perenes. As classes urbanização e represa foram propostas por Borges et al. (1993) e Anderson et al. (1976), respectivamente.

Após a interpretação das fotografias aéreas, os polígonos foram agrupados e digitalizados manualmente, com auxílio de mesa digitalizadora Calcomp 9500 e utilizando o módulo Arcedit do programa Arc-Info 7.3.1. para estação de trabalho. As áreas de interpretação duvidosa nas fotografias foram visitadas no campo para determinar o seu uso corretamente. Um receptor de Sistema de Posicionamento Global (GPS), marca Garmin 48, com 12 canais e fotografias aéreas foram utilizadas no trabalho de campo, no qual o uso da área foi verificado e 18 pontos de controle foram marcados.

Na elaboração dos mapas de uso e cobertura do solo um mesmo padrão de fotointerpretação foi seguido, possibilitando a comparação entre os mapas dos diferentes 
anos. Pequenas áreas de solo exposto, sem aspectos associados que indicassem o destino a ser dado a estas áreas, foram classificadas como áreas de pastagem. Áreas com coberturas vegetais em estágio inicial de regeneração, considerando-se aspectos associados e indícios de realmente terem sido abandonadas, foram consideradas como fragmentos florestais por já contribuírem com a manutenção da qualidade da água, ajudando a impedir a erosão e assoreamento dos corpos d'água.

Com o objetivo de completar a série histórica, fotografias aéreas de 1940 (escala 1:20.000) e de 1978 (escala 1:35.000), da empresa Terra Foto S.A., referentes à aproximadamente metade da área da bacia do ribeirão dos Marins foram obtidas com o Prof. Rubens Angulo Filho do Departamento de Engenharia Rural da ESALQ/USP e na Universidade Federal de São Carlos - Campus Araras. O vôo de 1978 não cobre toda a área de estudo e fotografias de 1940 referentes ao restante da área da bacia não foram encontradas em diversas instituições, órgãos e universidades que possuem acervos fotográficos da região.

As fotografias aéreas de 2000 encontravam-se no formato digital. As de 1940, 1962, 1978 e 1995 foram escaneadas com resolução de 300 pontos por polegada. Devido o longo tempo necessário para elaborar os mapas de uso e cobertura do solo e montar mosaicos georreferenciados a partir destas fotografias, estes foram elaborados apenas para os anos de 1962, 1995 e 2000, os quais permitem uma análise satisfatória das mudanças que ocorreram ao longo do tempo em toda a área de estudo. Desse modo, as fotografias de 1940 e 1978, correspondentes à metade da área de estudo, foram utilizadas apenas para demonstrar a dinâmica do uso e cobertura do solo em algumas áreas representativas, através das quais podemos constatar claramente as mudanças que ocorreram ao longo desta série histórica mais completa.

Os mosaicos digitais das fotografias aéreas foram elaborados para a obtenção de um mapa de vegetação mais detalhado, elaborado a partir das classes de uso e cobertura do solo (fragmentos florestais e floresta plantada). O objetivo foi de especificar as mudanças que estavam ocorrendo nas classes referentes as florestas, subdividindo estas de acordo com as suas características e estágio de regeneração. Posteriormente à elaboração dos mosaicos, uma correção dos deslocamentos dos mapas de uso e cobertura 
do solo de 1962, 1995 e 2000 em relação aos mosaicos dos anos correspondentes foi realizada. Esta correção foi necessária para reparar algumas distorções nos formatos e tamanhos dos polígonos, que podem ter ocorrido na etapa de elaboração dos referidos mapas, bem como uniformizar a base cartográfica de referência. O mapa de uso e cobertura do solo corrigido foi então utilizado como base para a elaboração do mapa de vegetação.

Estes deslocamentos corrigidos dos mapas gerados inicialmente pelo processo de fotointerpretação e digitalização são provenientes do georreferenciamento destes, o qual foi realizado com 18 pontos de controle levantados em trabalho de campo com um GPS. Este número de pontos utilizado é muito pequeno para georreferenciar o mapa com a mesma precisão das fotografias, para as quais foram utilizados no mínimo 400 pontos de controle. Outras possíveis distorções são características da própria fotografia, das etapas de contorno e digitalização dos polígonos do mapa de uso e cobertura do solo.

Para a correção conforme foi mencionada, o programa ERDAS IMAGINE 8.6. foi utilizado para georreferenciar as fotografias e o ArcGIS 8.3 e Arc-Info 7.3.1 para editar o mapa novamente. Finalizado o processo de correção dos mapas, a existência de transformações do uso e cobertura do solo que ocorrem com menor freqüência ou que possivelmente não deveriam ocorrer entre alguns dos anos analisados foram verificadas e corrigidas quando necessárias, minimizando os possíveis erros de interpretação e do processo de elaboração dos mapas. Desse modo, após todas estas etapas e a correção, foram obtidos os mapas de uso e cobertura do solo utilizados neste trabalho para os três anos.

\section{Mosaico das fotografias aéreas}

Os mosaicos digitais das fotografias aéreas foram elaborados utilizando o programa ERDAS IMAGINE 8.6. Uma correção geométrica foi realizada com base em pontos reconhecidos nas fotos e no mapa de referência utilizado (Figura 4), o qual era composto pela rede de drenagem (IGC, 1977, 1978 e 1979), pelo mapa de ruas e estradas (SEMAE, 2003), pelo mapa de estradas do Plano Diretor Rural de Piracicaba e 
de estradas das cartas do IGC. Para possibilitar uma boa junção das fotografias e formar o mosaico, pontos das fotografias georreferenciadas também foram utilizados.

A resolução das fotografias georreferenciadas utilizadas para montar os mosaicos foi calculada com base na escala e na resolução de 300 pontos por polegada utilizada para escaneá-las. Assim, para as fotografias de 1962 e 1995, escala 1:25.000, foi determinado que estas eram compostas por aproximadamente 118 pontos por centímetro, a célula destes mosaicos tinha uma resolução aproximada de 2 metros. As fotografias aéreas digitais e o mosaico de 2000 tinha uma resolução aproximada de 1 metro.

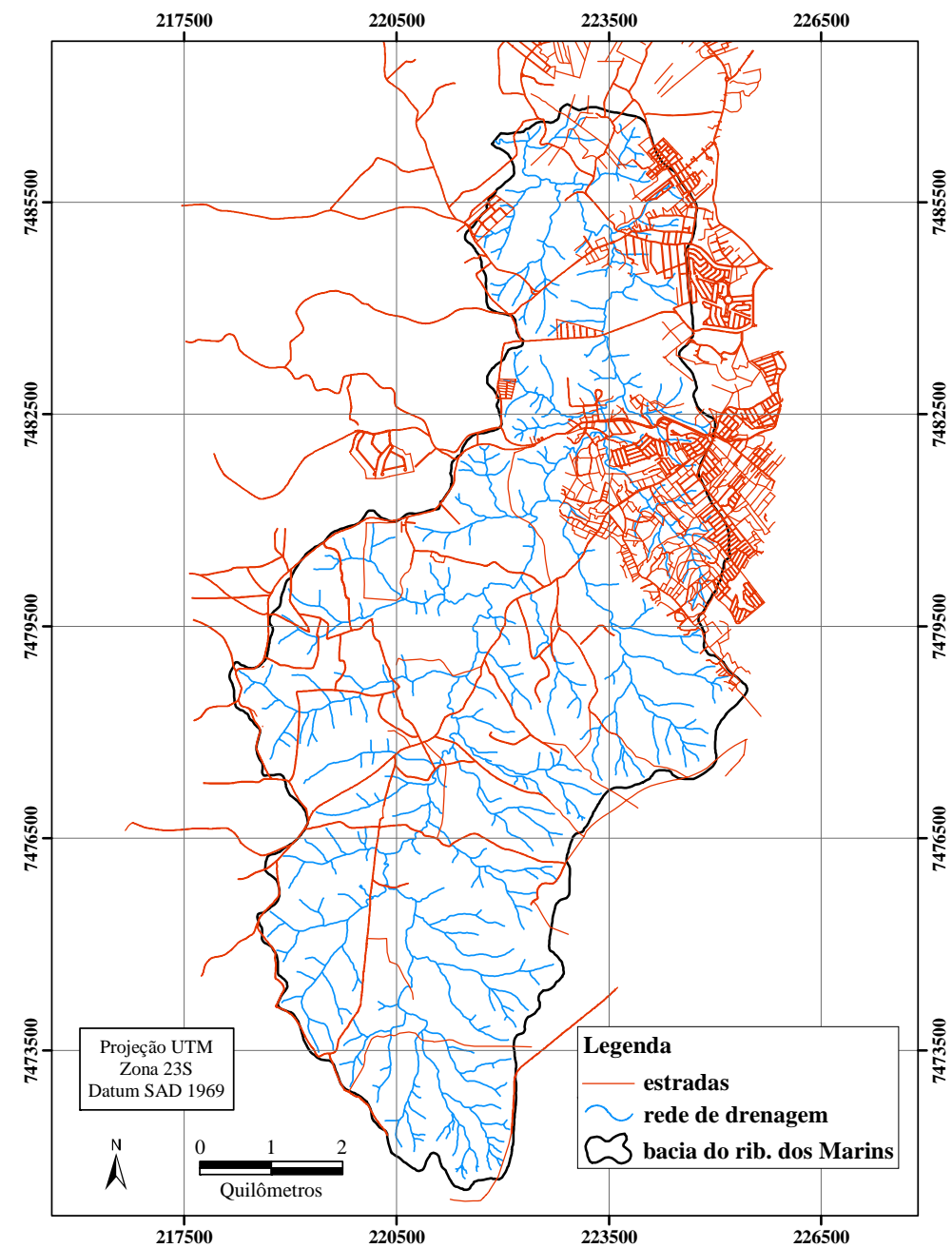

Figura 4 - Mapa de referência utilizado para correção geométrica das fotografias aéreas da bacia dos Marins 
Para o georreferenciamento foram identificados no mínimo 6 pontos de controle para cada imagem de 1000 x 1000 células. A transformação de coordenadas foi feita usando um polinômio linear de $1^{\mathrm{a}}$ ordem. A seguir foram analisados os erros obtidos nos ajustes entre os pontos de controle e os seus equivalentes na imagem, considerando como margem de erro recomendável 1 célula. Posteriormente, a imagem original foi transformada em uma nova imagem corrigida segundo a projeção cartográfica do mapa utilizado como referência. Nesse processo, o programa também realiza um processo de reamostragem por interpolação para corrigir os números digitais dessa nova imagem. Para esse procedimento foi utilizado o método do vizinho próximo, o qual é o que mais preserva o valor original dos números digitais, uma vez que não envolve nenhuma média (Crósta, 1992). Os valores do erro médio quadrático (RMS), cujo resultado é dado em células, foram 0,0208 para 1962 e 0,0238 para 1995.

O RMS resultante da correção geométrica das fotografias aéreas de 2000, foi bem maior que uma célula, com valores médios de 11,9419. Uma possível justificativa para os valores do RMS elevados é o fato das fotografias de 2000 terem uma resolução espacial mais detalhada, ao contrário do mapa de referência utilizado, o que faz com que pequenas diferenças se reproduzam em erros muito elevados. Para georreferenciar as fotografias de 2000 os pontos utilizados foram escolhidos de forma a manter o mínimo erro possível para realizar a correção geométrica destas.

Com base no mosaico de 2000, um mapa atualizado com as principais vias de acesso à urbanização, escoamento de produção, ruas e estradas foi elaborado utilizando os programas ArcGIS 8.3 e Arc-Info 7.3.1.

\section{Mapa de vegetação}

O mapa de vegetação de 1962, 1995 e 2000 foi elaborado a partir dos mosaicos georreferenciados, por interpretação visual, tendo como base os mapas de uso e cobertura do solo associados aos mosaicos correspondentes e auxílio de estereoscopia. Estes mapas foram elaborados para possibilitar uma análise mais detalhada da dinâmica desta classe na área de estudo, uma vez que a vegetação nos mapas de uso e cobertura do solo estava classificada apenas como floresta plantada e fragmento florestal. Assim, não 
possibilitavam a afirmação das mudanças que realmente estavam ocorrendo, por esta englobar tanto áreas em regeneração como áreas com formações florestais mais desenvolvidas. Neste mapa a classe fragmentos florestais é constituída por duas novas classes, regeneração e floresta nativa, possibilitando uma melhor compreensão do aumento desta no período de 1962 a 2000. A classificação da vegetação foi realizada considerando aspectos de interpretação visual como textura, padrão e forma.

O mapa de vegetação é composto pelas seguintes classes:

- Floresta plantada: nesta categoria são consideradas as formações arbóreas homogêneas, áreas com plantio de Eucalyptus ou Pinus instaladas pelo homem, para fins industriais ou para consumo dos estabelecimentos rurais; textura fina e média; porte médio a alto; tonalidade cinza médio a escuro intenso. Aspectos associados: telhado uniforme, em geral limites regulares e carreadores definidos. Conforme definição do IBGE (2004), a qual pode ser considerada para este trabalho, floresta plantada pode ser entendida como formação florestal composta por espécies exóticas e/ou nativas, plantadas com objetivos específicos.

- Floresta nativa: abrange as áreas ocupadas pelas diferentes formações florestais nativas existentes na bacia; áreas onde foram realizados plantios de florestas nativas; e pequenas áreas ocupadas com Eucalyptus antigos, sem características próprias de um plantio comercial, sempre associado à vegetação arbórea natural em estágio avançado de regeneração; textura média a grossa, porte médio a alto, tonalidade cinza médio a escuro. Aspectos associados: telhado desuniforme; geralmente limites irregulares e ausência de carreadores.

- Regeneração: áreas associadas a vegetação arbórea natural em estágio inicial e médio de regeneração, sendo proveniente de plantios de florestas nativas ou áreas abandonadas que estão em regeneração; textura fina a média, porte baixo a médio.

\section{Áreas de Preservação Permanente e Reserva Legal}

Conforme o inciso II do $\S 2^{\circ}$ do art. $1^{\circ}$ da Medida Provisória (MP) 2.166-67, de 24/08/01, “área de preservação permanente é aquela protegida nos termos dos arts. $2^{\circ}$ e $3^{\circ}$ do Código Florestal, coberta ou não por vegetação nativa, com a função ambiental de 
preservar os recursos hídricos, a paisagem, a estabilidade geológica, a biodiversidade, o fluxo gênico da fauna e flora, proteger o solo e assegurar o bem-estar das populações humanas”.

As áreas de preservação permanente são estabelecidas pelo artigo $2^{\circ}$ do Código Florestal vigente (Lei Federal 4771 de 15/09/65, alterada pela Lei Federal 7803 de 18/07/89) como sendo as florestas e demais formas de vegetação natural situadas:

- ao longo dos rios ou de qualquer curso d’água, sendo a largura mínima de preservação estabelecida de acordo com a largura dos cursos d’água. Para os cursos d’água de menos de 10 metros, a largura mínima estabelecida é de 30 metros. Para os cursos d’água de 10 a 50 e de 50 a 200 metros, as larguras mínimas estabelecidas são de 50 e 100 metros respectivamente (Art. $2^{\circ}$ do Código Florestal).

- ao redor das lagoas, lagos ou reservatórios d’água naturais ou artificiais (limites estabelecidos pela resolução CONAMA nº 302 e 303 de 20/03/02).

- nas nascentes, ainda que intermitentes e nos chamados "olhos d’água", qualquer que seja a sua situação topográfica, num raio mínimo de 50 metros de largura.

- no topo de morros, montes, montanhas e serras. A resolução CONAMA nº 303/02 estabelece as definições e especifica o que devem ser considerados para estes como sendo de preservação.

- nas encostas ou partes destas, com declividade superior a $45^{\circ}$, equivalente a $100 \%$ na linha de maior declive.

- nas restingas, como fixadoras de dunas ou estabilizadoras de mangues.

- nas bordas dos tabuleiros ou chapadas, a partir da linha de ruptura do relevo, em faixa nunca inferior a 100 metros em projeções horizontais.

- $\quad$ em altitude superior a 1800 metros, qualquer que seja a vegetação.

Para determinar as Áreas de Preservação Permanente também deve ser considerada a Resolução CONAMA n 303/02 a qual estabelece parâmetros, definições e limites referentes a estas.

De acordo com o parágrafo único do art. $2^{\circ}$ da Lei 7.803/89, no caso de áreas urbanas e nas regiões metropolitanas e aglomerações urbanas, deverá ser observado o 
que está estabelecido pelos respectivos planos diretores e leis de uso do solo, respeitando os princípios e limites estabelecidos pelo art. $2^{\circ}$ do Código Florestal.

Pelo art. $3^{\circ}$ da referida Lei, também são consideradas de preservação permanente, quando declaradas por ato do Poder Público, as florestas e demais formas de vegetação natural destinadas a:

- atenuar a erosão das terras;

- fixar as dunas;

- formar as faixas de proteção ao longo das rodovias e ferrovias;

- auxiliar a defesa do território nacional, a critério das autoridades militares;

- proteger sítios de excepcional beleza ou de valor científico ou histórico;

- asilar exemplares da fauna ou flora ameaçadas de extinção;

- manter o ambiente necessário à vida das populações silvícolas;

- assegurar condições de bem estar público.

Com base na legislação apresentada, os critérios considerados para a determinação das Áreas de Preservação Permanente (APPs) na bacia dos Marins foram:

- 30 metros de largura a partir da rede de drenagem da bacia do ribeirão dos Marins;

- 100 metros a partir do rio Piracicaba.

Essas áreas foram determinadas pelo programa ArcGIS 8.3, tendo como base os critérios citados acima e o mapa da rede de drenagem.

Com relação à declividade, as áreas com valores acima de 45 graus constituíam apenas 225 metros quadrados da área da bacia. Como estas áreas estavam heterogeneamente distribuídas na bacia e a área das mesmas era muito pequena, com um percentual praticamente nulo em relação à área total, estas regiões foram desconsideradas para a determinação da área de preservação permanente de acordo com a legislação.

Neste trabalho foram consideradas as APPs apenas dos cursos d’água devido serem consideradas suficientes e adequadas para a análise temporal proposta, analisando a situação destas. No entanto, levantamentos de campo foram realizados com o intuito de determinar as APPs ao redor das nascentes e das lagoas, lagos ou reservatórios d’água naturais ou artificiais. Diante da necessidade de novos levantamentos de campo para 
identificar e classificar estas, de atualização da rede de drenagem e de um detalhamento maior das informações, para identificar as diversas especificações e atender aos critérios estabelecidos para se delimitar estas áreas para cada situação estabelecida pela legislação, optou-se por deixar este análise para um outro trabalho e não considerar estas áreas neste estudo.

O Código Florestal também estabelece, além das Áreas de Preservação Permanente, a Reserva Legal (RL). Conforme o inciso III do $\S 2^{\circ}$ do Art. $1^{\circ}$ da Medida Provisória (MP) 2.166-67, de 24/08/01, “Reserva Legal é a área localizada no interior de uma propriedade ou posse rural, excetuada a de preservação permanente, necessária ao uso sustentável dos recursos naturais, à conservação e reabilitação dos processos ecológicos, à conservação da biodiversidade e ao abrigo e proteção de fauna e flora nativas".

No artigo 16 do Código Florestal vigente (Lei Federal 4771 de 15/09/65, alterada pela Lei Federal 7803 de 18/07/89 e Medida Provisória 2.166-67 de 24/08/01) foi estipulada para a região Sudeste uma área mínima de $20 \%$ da propriedade com cobertura florestal para ser mantida a título de reserva legal. A vegetação da RL não pode ser suprimida, podendo apenas ser utilizada sob regime de manejo florestal sustentável, de acordo com princípios e critérios técnicos e científicos que foram estabelecidos pela legislação.

De acordo com $\S 6^{\circ}$ do artigo 16 do Código Florestal vigente, as áreas relativas à vegetação nativa existente em APP poderão ser consideradas no cálculo do percentual de reserva legal, desde que isto não implique em conversão de novas áreas para o uso alternativo do solo, e quando a soma da vegetação nativa em APP e RL exceder 50 \% da propriedade rural localizada na região Sudeste ou $25 \%$ da pequena propriedade definida no artigo $1^{\circ}$ do Código Florestal. A pequena propriedade rural é explorada mediante o trabalho pessoal do proprietário ou posseiro e de sua família e a área não supera 30 hectares quando localizada no estado de São Paulo.

Para cumprimento da manutenção ou compensação da área de reserva legal em pequena propriedade, conforme o $\S 3^{\circ}$ do artigo 16, podem ser computados os plantios de árvores frutíferas ornamentais ou industriais, compostos por espécies exóticas, 
cultivadas em sistema intercalar ou em consórcio com espécies nativas. O $\S 8^{\circ}$ do mesmo artigo especifica que a localização da reserva legal deve ser aprovada pelo órgão ambiental estadual competente e sua área averbada à margem da inscrição de matrícula do imóvel, sendo vedada a alteração de sua destinação, nos casos de transmissão, a qualquer título, de desmembramento ou de retificação da área, com as exceções previstas no Código Florestal.

Conforme o artigo 44 do Código Florestal, o proprietário com área de floresta nativa, natural, primitiva ou regenerada ou outra forma de vegetação nativa em extensão inferior ao estabelecido no artigo 16 do código florestal deve:

- Recompor a reserva legal de sua propriedade mediante o plantio, a cada três anos, de no mínimo 1/10 da área total necessária à sua complementação, com espécies nativas, de acordo com critérios estabelecidos pelo órgão ambiental estadual competente. A recomposição pode ser realizada mediante o plantio temporário de espécies exóticas como pioneiras, visando a restauração do ecossistema original, de acordo com critérios técnicos gerais estabelecidos pelo CONAMA (Conselho Nacional do Meio Ambiente).

- Conduzir a regeneração natural da reserva legal, a qual será autorizada pelo órgão ambiental competente, quando sua viabilidade for comprovada por laudo técnico, podendo ser exigido o isolamento da área.

- Compensar a reserva legal por outra área equivalente em importância ecológica e extensão, desde que pertença ao mesmo ecossistema e esteja localizada na mesma microbacia, conforme critérios estabelecidos em regulamento. A compensação deverá ser submetida à aprovação pelo órgão ambiental estadual competente.

A legislação deixa clara a obrigação de recomposição florestal da área da reserva legal, apesar da morosidade. O fato de não ter cobertura arbórea na propriedade não elimina o dever do proprietário de instaurar a Reserva Florestal. Apesar do prazo estabelecido para a recomposição, a obrigação do proprietário de manter desde já a área reservada na proporção estabelecida não é retirada. O proprietário não pode exercer atividade agropecuária ou de exploração mineral mesmo que na área da reserva legal inexista floresta. A área da Reserva Legal desmatada anteriormente ou não, deverá ter cobertura arbórea pela regeneração natural ou pela ação humana (Machado, 2002). 
De acordo com o Decreto 3.179/99 são consideradas infrações a exploração da área de Reserva Legal sem autorização ou aprovação prévia do órgão ambiental competente ou sem a adoção de técnicas de manejo e de reposição florestal devidamente inseridas nos planos previamente aprovados pelo órgão ambiental. Também é considerado ilícito qualquer corte raso na mesma.

A Reserva Legal incide somente sobre o domínio privado. Atualmente, a reserva legal é exigida nos casos de supressão de vegetação nativa, corte ou exploração da vegetação ou no caso de compensação de algum dano, diante da necessidade de adequarse a legislação vigente devido pedido de um promotor (Artigos $16^{\circ}$ e $44^{\circ}$ do Código Florestal vigente). Contudo, a aplicação dessa exigência de averbação da RL varia conforme a regulamentação realizada a nível estadual, sendo que apenas em alguns estados a averbação é exigida pelo cartório ao se realizar um desmembramento. No estado de São Paulo a regulamentação do processo de averbação da Reserva Legal ainda não ocorreu efetivamente para determinados aspectos.

Para uma análise mais detalhada da situação da Reserva Legal na bacia dos Marins, seria necessária uma análise específica para cada uma das propriedades. Assim, como não foi possível obter e trabalhar com as propriedades da área completa, uma abordagem geral do percentual de Reserva Legal em relação à vegetação presente na bacia em 2000 foi realizada.

Uma conclusão se a situação da Reserva Legal nas propriedades da bacia está adequada não é possível, uma vez que existem diversas condições específicas ao se estabelecer a Reserva Legal. Dentre elas, cabe ressaltar a possibilidade, para determinadas situações, de considerar as áreas relativas à vegetação nativa existente na APP no cálculo do percentual de reserva legal. Os plantios de árvores frutíferas ornamentais ou industriais também podem ser computados no cálculo da RL de algumas propriedades. O prazo estabelecido para a recomposição da RL e a possibilidade de compensar a reserva legal por outra área equivalente em importância ecológica e extensão, também dificultam a análise. 


\section{Erosão}

Mapas de risco potencial de erosão da bacia dos Marins foram elaborados a partir da aplicação da Equação Universal de Perda de Solo (EUPS). Esta equação, desenvolvida Wischmeier \& Smith (1978), exprime a ação dos principais fatores que influenciam a erosão pela chuva e é expressa em função de seis variáveis ambientais e de manejo (equação 1):

$$
\mathrm{A}=\text { R.K.L.S.C.P }
$$

onde:

$\mathrm{A}=$ estimativa de perda de solo por unidade de área para um intervalo de tempo (t ha ${ }^{-1}$ para o intervalo de tempo utilizado no cálculo da erosividade, ano ou mês);

$\mathrm{R}$ = erosividade (MJ mm ha ${ }^{-1} \mathrm{~h}^{-1}$ por ano ou para um mês). Fator que expressa a capacidade da chuva em provocar erosão;

$\mathrm{K}$ = erodibilidade $\left(\mathrm{t} \mathrm{h} \mathrm{MJ}^{-1} \mathrm{~mm}^{-1}\right)$. Fator relativo às propriedades inerentes ao solo, tais como textura, estrutura, matéria orgânica e permeabilidade, e que reflete sua maior ou menor susceptibilidade à erosão;

$\mathrm{L}$ = fator relativo ao comprimento de declive da encosta (adimensional);

$\mathrm{S}$ = fator relativo à declividade da encosta. Corresponde à relação de perdas de solo entre um comprimento de declive qualquer e um declive de $9 \%$ para o mesmo solo e comprimento de rampa. Integrado ao fator L, define o fator topográfico (adimensional); $\mathrm{C}=$ fator relativo ao uso e manejo. Varia de 0 para coberturas que proporcionam uma proteção total do solo a 1 para solos inteiramente expostos (adimensional); $\mathrm{P}=$ fator relativo à prática conservacionista adotada (adimensional).

O fator erosividade da chuva (R) é um índice numérico que expressa a capacidade da chuva, de uma dada localidade, causar erosão em uma área sem proteção. O produto da energia cinética da intensidade da chuva é considerada a melhor relação encontrada para medir a potencialidade erosiva da chuva (Bertoni \& Lombardi Neto, 1990). O índice de erosão médio anual (fator R) é determinado pela soma dos valores 
mensais dos índices de erosividade, os quais foram determinados conforme propostos por Lombardi Neto \& Moldenhauer (1992) (equação 2):

$\mathrm{EI}=68,730\left(\mathrm{r}^{2} / \mathrm{P}\right)^{0,841}$

onde:

$\mathrm{EI}=$ média mensal do índice de erosividade em $\mathrm{MJ} \mathrm{mm} \mathrm{ha}^{-1} \mathrm{~h}^{-1}$;

r = precipitação média mensal em milímetros;

$\mathrm{P}=$ precipitação média anual em milímetros.

Neste trabalho, a erosividade corresponde ao índice médio mensal de janeiro e julho, representando as estações chuvosa e seca, respectivamente. Para o cálculo foram utilizados os dados do posto Agrometeorológico da Escola Superior de Agricultura “Luiz de Queiroz” (ESALQ) em Piracicaba, de 1917 a junho de 2004.

A erodibilidade do solo $(\mathrm{K})$ é sua vulnerabilidade ou suscetibilidade à erosão, que é recíproca à resistência à erosão. Um solo com alta erodibilidade sofrerá mais erosão que um com baixa erodibilidade se ambos estiverem expostos a uma mesma chuva. A erodibilidade pela água é influenciada pelas propriedades do solo, que afetam a velocidade de infiltração, permeabilidade e capacidade de absorção da água, e que resistem às forças de dispersão, salpico, abrasão e transporte pela chuva e escoamento.

O significado de erodibilidade do solo é diferente da erosão do solo. A intensidade de erosão de uma área qualquer pode ser influenciada mais pelo declive, características da chuva, cobertura vegetal e manejo, do que pelas propriedades do solo. Contudo, alguns solos são mais facilmente erodidos que outros, mesmo quando estas características são as mesmas. Essa diferença, devido às propriedades inerentes ao solo, resultam da erodibilidade do solo (Bertoni \& Lombardi Neto, 1990).

Para a determinação da erodibilidade $(\mathrm{K})$ foi utilizada a metodologia apresentada por Cerri (1999). O fator K foi calculado pela equação de Denardin (1990), adaptada por Levy (1995), conforme apresentada na equação 3: 


$$
\mathrm{K}=0,00000748(\mathrm{M})+0,00448059(\mathrm{P})-0,06311750(\mathrm{DMP})+0,01039567(\mathrm{R})
$$

onde:

$\mathrm{K}$ = valor estimado para o fator erodibilidade do solo, em $\mathrm{th} \mathrm{MJ}^{-1} \mathrm{~mm}^{-1}$;

M = variável adimensional calculada a partir de parâmetros granulométricos, ou seja, [(\% silte $+\%$ areia fina $) *(\%$ silte $+\%$ areia fina $+\%$ areia grossa $)]$;

$\mathrm{P}$ = permeabilidade do solo, em função de sua textura e estrutura, de acordo com as seguintes classes estabelecidas por Wischmeier et al. (1971): 1 = rápida; 2 = moderada a rápida; 3 = moderada; 4 = lenta a moderada; 5 = lenta; 6 = muito lenta;

DMP = diâmetro médio ponderado das partículas menores que $2 \mathrm{~mm}$, ou seja, [(0,65 * $\%$ areia grossa $)+(0,15 * \%$ areia fina $)+(0,0117 * \%$ silte $)+(0,00024 * \%$ argila $)] /$ 100 (Ranieri, 1996);

$\mathrm{R}=$ relação entre teor de matéria orgânica e o teor da areia grossa $(\mathrm{MO} * \%$ areia grossa)/100;

$\mathrm{MO}=\%$ de carbono * 1,73 (Giboshi, 1999).

A equação foi aplicada para os solos existentes na bacia, tomando como base a carta semi-detalhada, obtida do banco de dados georreferenciado do Projeto Piracena (www.cena.usp.br), na escala 1:100.000, quadrícula de Piracicaba. As características médias dos solos da carta semi-detalhada referentes ao horizonte A do perfil do solo, necessárias para o cálculo do fator K, foram retiradas de Oliveira, J. (1999).

O mapa de solos no formato digital foi convertido para o formato em grade com resolução de 5 metros e reclassificado com os valores calculados de erodibilidade para cada unidade de mapeamento, resultando no mapa de erodibilidade dos solos.

Para os solos litólicos substrato das Formações Botucatu ou Pirambóia (Li5) e substrato basalto ou diabásio (Li6), devido à falta de dados médios para estes na referência utilizada (Oliveira, J. 1999), optou-se por utilizar valores dos solos litólicos com características mais próximas a deles, por ser da mesma unidade ou apresentar uma textura mais próxima. Cabe ressaltar que esta aproximação feita não deve afetar o resultado dos cálculos, uma vez que o solo Li6 aparece associado à Terra Roxa Estruturada em menos de $1 \%$ da bacia e o solo Li5, além de utilizarmos dados de outro solo litólico com substrato da mesma Formação, representa menos de $5 \%$ da área da 
bacia. O fato de estar utilizando valores médios de cada tipo de solo de acordo com as Unidades correspondentes e a escala do mapa de solos não ser detalhada o suficiente, justifica a utilização de dados de outros solos litólicos para o cálculo do fator K do Li5 e Li6, sendo ambos classificados como Neossolo Litólico Eutrófico pela nova nomenclatura utilizada para a classificação de solos (EMBRAPA, 1999).

Para as associações de solo, unidades do mapa compostas pelo agrupamento de duas ou três classes de solos, o índice de erodibilidade foi estabelecido calculando-se a média ponderada entre os valores do fator $\mathrm{K}$ de cada classe. Para isso foi utilizado o seguinte critério (Giboshi, 1999):

- Associação de duas classes de solos: 60 \% corresponde a primeira e 40 \% a segunda classe.

- Associação de três classes de solos: 50\% da primeira, 30\% da segunda e $20 \%$ da terceira classe.

Os valores de erodibilidade calculados para cada unidade de mapeamento, considerando as associações de solos existentes, referente ao mapa de solos semidetalhado da bacia dos Marins são apresentados na Tabela 3.

Tabela 3. Valores de erodibilidade para as unidades de solo da bacia dos Marins

\begin{tabular}{cc}
\hline Unidade de mapeamento & Fator $\mathbf{K}\left(\mathrm{t} \mathrm{h} \mathrm{MJ}^{-1} \mathrm{~mm}^{-1}\right)$ \\
\hline LE2+PE & 0,0245 \\
LV2 & 0,0271 \\
Li3 & 0,0487 \\
Li5 & 0,0591 \\
PV10+Li3+PV9 & 0,0442 \\
PV7 & 0,0464 \\
PV7+PV8 & 0,0464 \\
TE1 & 0,0214 \\
TE1+Li6 & 0,0323 \\
TT1 & 0,0000 \\
\hline
\end{tabular}

LE2: Latossolo Vermelho Distrófico; LV2: Latossolo Vermelho-Amarelo Distrófico; PV7, PV8: Argissolo Vermelho-Amarelo; PV9: Argissolo Amarelo; PV10: Argissolo Vermelho-Amarelo Eutrófico; PE: Argissolo Vermelho; TE1: Nitossolo Vermelho Eutrófico; Li3: Neossolo Litólico Eutrófico ou Distrófico; Li5, Li6: Neossolo Litólico Eutrófico; TT_1: Tipos de Terreno - Extração de pedra. 
O fator topográfico (LS) foi obtido através da multiplicação do fator L, relativo ao comprimento de declive (ou da rampa), pelo fator $\mathrm{S}$ relativo à declividade (Bertoni \& Lombardi Neto, 1990). A metodologia utilizada foi descrita por Hickey et al. (1994). Os fatores L e S foram calculados no Sistema de Informação Geográfica (SIG) ArcInfo 7.3.1 tendo como base o mapa de declividade em graus e de direção de fluxo. O mapa de direção de fluxo foi gerado através de uma extensão de modelagem hidrológica, a qual utiliza para o cálculo um algoritmo que identifica a direção para a qual cada célula do mapa transporta água baseada na altura da célula e de seus oito vizinhos.

A equação utilizada para o cálculo do LS é expressa da seguinte forma:

Fator LS $=(\lambda / 25)^{t}\left(65,41 \operatorname{sen}^{2} \beta+4,56 \operatorname{sen} \beta+0,065\right)$

sendo:

$\mathrm{t}=0,5$ se declive $\beta>3^{\circ} ; \mathrm{t}=0,4$ se declive $1,7^{\circ}<\beta<3^{\circ} ; \mathrm{t}=0,3$ se declive $0,6^{\circ}<\beta<1,7^{\circ}$ e $\mathrm{t}=0,2$ se declive $\beta<0,6^{\circ}$.

onde:

$\lambda=$ comprimento de declive acumulado;

$\beta$ = ângulo da declividade morro abaixo;

t = inclinação da variável contingencial.

O fator cultural (C) ou uso e manejo do solo é a relação esperada entre as perdas de solo de um terreno cultivado em dadas condições e as perdas correspondentes de um terreno mantido continuamente descoberto. Em uma área cultivada, as perdas são reduzidas devido à proteção que a cultura oferece ao solo (Bertoni \& Lombardi Neto, 1990). Os mapas do fator cultural C para 1962, 1995 e 2000 foram elaborados a partir dos mapas de uso e cobertura do solo dos anos correspondentes, os quais foram convertidos para o formato em grade com resolução de 5 metros e reclassificados com os valores, obtidos de Cerri (1999), Castro (1992) e Lombardi Neto (2004) ${ }^{1}$, correspondentes a cada classe de uso e cobertura do solo (Tabela 4).

${ }^{1}$ LOMBARDI NETO, F. Comunicação pessoal, 2004. 
Tabela 4. Valores do fator cultural (C) correspondentes as diferentes classes de uso e cobertura do solo

\begin{tabular}{ll}
\hline Uso e cobertura do solo & Fator C \\
\hline Pasto & $0,01000^{\mathrm{a}, \mathrm{b}}$ \\
Cana-de-açúcar & $0,11240^{\mathrm{a}}$ \\
Fragmento florestal & $0,00004^{\mathrm{b}}$ \\
Silvicultura / Reflorestamento & $0,00010^{\mathrm{b}}$ \\
Culturas Anuais & $0,08270^{\mathrm{a}}$ \\
Culturas Perenes & $0,13500^{\mathrm{a}}$ \\
Urbanização & $0,00300^{\mathrm{b}}$ \\
Represas & $0^{\mathrm{a}}$ \\
Hortas & $0,01850^{\mathrm{c}}$ \\
\hline
\end{tabular}

Fonte: ${ }^{\mathrm{a}}$ Cerri (1999)

${ }^{\mathrm{b}}$ Castro (1992)

${ }^{\mathrm{c}}$ Lombardi Neto (2004) ${ }^{1}$

O fator prática conservacionista (P) é a relação entre a intensidade esperada de tais perdas com determinada prática conservacionista e aquelas quando a cultura está plantada no sentido do declive (morro abaixo). As práticas conservacionistas mais comuns para as culturas anuais são: plantio em contorno, plantio em faixas de contorno, terraceamento e alternância de capinas (Bertoni \& Lombardi Neto, 1990).

Para a aplicação da Equação Universal de Perda de Solo (EUPS) foram consideradas duas situações para a bacia dos Marins, na primeira considerou-se o valor do fator P como sendo igual a 0,5, correspondente à prática de plantio em contorno ou terraceamento, para toda a área da bacia. Numa segunda situação foi considerado o valor igual a 1, correspondente ao plantio morro abaixo.

Os mapas de risco potencial de erosão foram obtidos no programa ArcGIS 8.3 através da manipulação dos mapas acima descritos. Para a análise final foram estabelecidas quatro classes de risco de erosão, sendo consideradas áreas com perdas de solo até $2 \mathrm{t} \mathrm{ha}^{-1}$ mês $^{-1}$ de risco baixo, de 2 a $3 \mathrm{t} \mathrm{ha}^{-1}$ mês $^{-1}$ médio, de 3 a $10 \mathrm{t} \mathrm{ha}^{-1}$ mês ${ }^{-1}$ alto e maior que $10 \mathrm{t} \mathrm{ha}^{-1}$ mês $^{-1}$ de risco muito alto. 
Um mapa referente ao Potencial Natural de Erosão (PNE), que representa os parâmetros do meio físico (Donzeli et al., 1992), também foi elaborado utilizando os termos da EUPS de acordo com a equação (5). O PNE corresponde às estimativas de perdas de terra em áreas sem cobertura vegetal e sem a adoção de prática conservacionista.

$$
\text { PNE }=\text { R.K.L.S }
$$

onde:

$\mathrm{PNE}=$ potencial natural de erosão $\left(\mathrm{t} \mathrm{ha}^{-1} \mathrm{ano}^{-1}\right)$;

$\mathrm{R}=$ fator erosividade da chuva ( $\mathrm{MJ} \mathrm{mm} \mathrm{ha}{ }^{-1} \mathrm{~h}^{-1}$ por ano);

$\mathrm{K}=$ fator erodibilidade do solo $\left(\mathrm{t} \mathrm{h} \mathrm{MJ}^{-1} \mathrm{~mm}^{-1}\right)$;

L.S = fator topográfico (adimensional).

\section{Classificação adaptada de capacidade de uso do solo}

Segundo Lepsch (2004) ${ }^{2}$, para realizar a classificação proposta por ele com os objetivos originais (Lepsch, 1983), a interpretação do levantamento do meio físico deve ser efetuada no campo, sendo que faixas representativas englobando os diferentes tipos de solos e declividades deveriam ser percorridas e analisadas, possibilitando uma extrapolação das limitações identificadas para o restante da área através das fotografias aéreas.

Considerando o enfoque deste trabalho, o qual está mais relacionado à questão da influência do uso e cobertura do solo ao risco de erosão e não a perda de produtividade, optou-se por não fazer a classificação tradicional de capacidade de uso. Para tal, seria necessário um levantamento das áreas com fatores limitantes à mecanização, relacionados à pedregosidade, problemas de drenagem e algumas características específicas do solo. Um outro fator condicionante para a modificação desta metodologia é o fato dos dados disponíveis de fertilidade do solo não estarem em uma escala apropriada, uma vez que os perfis analisados não se encontram na área de estudo. Assim, o grau de detalhamento do levantamento de solos não foi adequado para empregar uma

\footnotetext{
${ }^{2}$ LEPSCH, I.F. Comunicação pessoal, 2004.
} 
classificação considerando a fertilidade e outras características limitantes dos solos na área de estudo.

Portanto, foi adotada uma classificação adaptada relacionando apenas alguns fatores físicos, os quais seriam limitantes devido ao risco de erosão. Cabe ressaltar, que o fator de maior influência na área de estudo é a declividade do terreno. Então, para esta classificação considerou-se apenas esta característica e o deflúvio, para qual foram consideradas seis classes de declividade (Tabela 5) e cinco classes relacionadas ao deflúvio (muito lento; lento; moderado; rápido e muito rápido). Estas foram determinadas através da metodologia proposta por Fujihara (2002) e Ribeiro \& Campos (1999).

Para determinar o deflúvio foi considerada a influência da declividade e do tipo de solo, relacionado à infiltração e a permeabilidade. A infiltração varia com o tipo do solo, quanto maior a infiltração menor a contribuição para o deflúvio. A declividade é diretamente proporcional à intensidade do deflúvio, de modo que quanto maior a declividade maior será o deflúvio (Fujihara, 2002). O deflúvio foi classificado através de uma somatória de notas atribuídas à declividade e à infiltração em relação ao tipo de solo, a qual foi reclassificada nas classes de capacidade de uso especificadas na Tabela 6.

Tabela 5. Classificação da declividade nas classes de capacidade de uso do solo

\begin{tabular}{cc}
\hline Declividade (\%) & Classe \\
\hline $0-3$ & I \\
$3-6$ & II \\
$6-12$ & III \\
$12-20$ & IV \\
$20-40$ & VI \\
$>40$ & VII \\
\hline
\end{tabular}

Fonte: Ribeiro \& Campos (1999) e Fujihara (2002). 
Tabela 6. Relação entre o deflúvio e a classe de capacidade de uso do solo

\begin{tabular}{lcc}
\hline Classificação & Intervalos de enquadramento & Classe \\
\hline muito lento & 3 & II \\
lento & 4 a 5 & I \\
moderado & 6 a 7 & II \\
rápido & 8 a 9 & III \\
muito rápido & 10 a 11 & IV \\
\hline
\end{tabular}

Fonte: Adaptado de Ribeiro \& Campos (1999) e Fujihara (2002).

Pela intersecção dos mapas das classes de declividade e do deflúvio, de acordo com o tipo de solo, no programa ArcGIS 8.3, um mapa foi obtido atribuindo-se os valores correspondentes à classe de capacidade mais restritiva destes fatores para as diferentes áreas. Posteriormente, este foi agrupado em três novas classes de acordo com o nível de limitação (Tabela 7) para obtenção do mapa final da classificação adaptada da capacidade de uso considerando restrições quanto ao risco de erosão.

Tabela 7. Classes finais da capacidade de uso adaptada para a bacia do ribeirão dos Marins

\begin{tabular}{lcc}
\hline Limitações quanto ao risco de erosão & Classes & Classes adaptadas \\
\hline Baixa a moderada & I,II,III & 1 \\
Severa & IV & 2 \\
Muito severa & VI, VII & 3 \\
\hline
\end{tabular}

As classes adaptadas apresentam as seguintes características:

- Classe 1: são terras com declividade até $12 \%$, com limitações à erosão que vão de pequenas a moderadas, quando consideramos apenas a declividade e o tipo do solo relacionado ao deflúvio. Elas são próprias para culturas anuais com práticas que variam de simples a intensivas de conservação do solo dependendo da declividade. Atenção deve ser dada às práticas que promovam a proteção contra a erosão ou risco de degradação.

- Classe 2: são terras severamente limitadas por risco de erosão para cultivos intensivos, geralmente com declividades acentuadas, com deflúvio que variam de 
moderado a rápido, com médio a alto potencial de erosão. Terras com declives até 20\%, onde as práticas conservacionistas são complexas. O uso com culturas anuais só deve ser recomendado sob manejo desenvolvido em rotação com pastagens e, de preferência devem ser aradas uma vez em cada quatro ou cinco anos, nessa rotação. Elas não devem ser continuamente utilizadas com culturas anuais. São adequadas às culturas perenes, também sob manejo complexo de práticas conservacionistas e para pastagens.

- Classe 3: são terras com relevo forte ondulado e declividades muito acentuadas, além do limite de mecanização, propiciando deflúvio moderado a muito rápido. Pelas condições topográficas, com risco de erosão que pode chegar a muito severo. Atenção deve ser dada à adoção de práticas conservacionistas adequadas. As áreas com declividade acima de 20 \% e menor que 40 \% são impróprias para culturas anuais, mas adaptadas para pastagens com restrições moderadas de uso desde que adequadamente manejadas. São adequadas para pastagens adaptadas que promovam a proteção do solo contra a erosão em declives mais acentuados. Quanto às áreas com declives acima de 40\%, são terras muito íngremes, erodidas, com limitações severas para outras atividades que não florestais. No geral, são mais adaptadas ao reflorestamento, observando-se o manejo de corte seletivo.

\subsection{Análise das mudanças}

Uma análise temporal das mudanças que ocorreram no uso e cobertura do solo foi realizada com base nos mapas destes gerados para os anos de 1962, 1995 e 2000. Para uma análise mais detalhada da dinâmica destas mudanças ao longo do tempo, uma matriz referente às substituições das áreas referentes as principais classes de uso foi elaborada.

Apesar do procedimento de correção dos mapas, pequenos deslocamentos entre os mesmos foram verificados devido a variações da qualidade da fotografia, pequenas distorções existentes entre algumas fotos ou pequenos deslocamentos que não puderam ser eliminados em algumas regiões dos mosaicos no processo de elaboração destes. Assim, apenas para realizar esta análise através da sobreposição dos mapas, os principais 
deslocamentos existentes entre os mapas de uso e cobertura do solo dos três anos foram corrigidos, possibilitando analisar as principais mudanças. Os mapas de 1962, 1995 e 2000 corrigidos foram transformados para o formato em grade, com células de $15 \mathrm{~m} x$ 15m, e foi realizada a sobreposição deles no programa ArcGIS 9.0. A partir deste procedimento foram geradas as matrizes de transição para as principais classes.

Para análise das mudanças da paisagem foram determinadas métricas da paisagem, com os mapas de uso de cobertura do solo dos três anos, através da extensão V-LATE 1.1 (Vector-based Landscape Analysis Tools) para o programa ArcGIS 9 (http://www.geo.sbg.ac.at/LARG/). Os índices foram calculados para a paisagem como um todo e para as classes de uso e cobertura do solo. Algumas métricas quantificam a composição, representam a variedade e abundância de fragmentos, e outras quantificam a configuração, a qual está relacionada à forma e posição dos mesmos em relação à paisagem.

Uma análise temporal das mudanças que ocorreram também foi realizada através dos mapas de 1962, 1995 e 2000 da vegetação e do risco de erosão. As mudanças do uso e cobertura do solo dos três anos nas classes de risco de erosão foram determinadas através da sobreposição dos mapas referentes a estes no ArcGIS 9.

\subsection{Adequabilidade do uso e cobertura do solo}

A análise temporal da adequabilidade do uso e cobertura do solo foi realizada através dos mapas de uso e cobertura do solo e de vegetação, de uma classificação adaptada da capacidade de uso do solo, das áreas de preservação permanente (APPs) estabelecidas pelo Código Florestal e do risco de erosão.

Uma análise temporal do uso e cobertura do solo nas APPs foi realizada através da manipulação dos mapas de uso e cobertura do solo, de vegetação e das APPs. A adequabilidade do uso do solo nestas áreas foi avaliada com base na legislação ambiental.

Para analisar a adequabilidade do uso e cobertura do solo em relação à classificação adaptada da capacidade de uso do solo, mapas da adequabilidade foram 
obtidos através da sobreposição do mapa de capacidade de uso do solo aos de uso e cobertura do solo dos três anos, sendo o uso classificado em três classes (adequado, adequado com restrições e inadequado), de acordo com as especificações da Tabela 8. Nesta classificação não foram consideradas áreas subutilizadas, pois devido estarmos analisando se o uso está adequado apenas em relação ao risco de erosão, uma área subutilizada é considerada adequada, uma vez que não favorecem os processos erosivos.

Tabela 8. Especificações para definição da adequação do uso

\begin{tabular}{lccc}
\hline \multirow{2}{*}{ Uso e cobertura do solo } & \multicolumn{3}{c}{ Classes adaptadas } \\
& $\mathbf{1}$ & $\mathbf{2}$ & $\mathbf{3}$ \\
\hline Pasto & $\mathrm{A}$ & $\mathrm{A}$ & $\mathrm{I}$ \\
Cana-de-açúcar & $\mathrm{A}$ & $\mathrm{AR}$ & $\mathrm{I}$ \\
Fragmento florestal & $\mathrm{A}$ & $\mathrm{A}$ & $\mathrm{A}$ \\
Floresta plantada & $\mathrm{A}$ & $\mathrm{A}$ & $\mathrm{A}$ \\
Culturas Anuais & $\mathrm{A}$ & $\mathrm{AR}$ & $\mathrm{I}$ \\
Culturas Perenes & $\mathrm{A}$ & $\mathrm{AR}$ & $\mathrm{I}$ \\
Hortas & $\mathrm{A}$ & $\mathrm{AR}$ & $\mathrm{I}$ \\
Urbanização & - & - & - \\
Represas & - & - & - \\
\hline A = Adequado; AR = Adequado com restrições e I = Inadequado.
\end{tabular}

A distribuição do uso e cobertura do solo nas diferentes classes de risco de erosão foi obtida através da sobreposição dos mapas correspondentes elaborados conforme metodologia apresentada no diagnóstico ambiental.

\subsection{Análise das relações}

As possíveis relações entre aspectos analisados foram avaliadas através da Correlação de Spearman utilizando o programa STATISTICA 6.0. A existência de correlação entre as diferentes classes de uso e cobertura do solo, risco de erosão e qualidade da água foram testadas. 


\section{RESULTADOS E DISCUSSÃO}

\subsection{Diagnóstico ambiental}

\section{Aspectos gerais}

A rede de drenagem e a área da bacia de drenagem pode ser visualizada na Figura 5. Como pode ser observado, a linha do divisor de águas apresenta contornos bem acentuados e curvilíneos, conferindo à bacia um perímetro de 43,3 km e uma área de 58,4 km². O canal principal percorre uma distância de aproximadamente 22,3 km da nascente até a foz. A rede de drenagem apresenta um comprimento de 188,1 km de cursos de água permanentes, o que resulta em uma densidade de drenagem da ordem de $3,2 \mathrm{~km} \mathrm{~km}^{-2}$. O maior comprimento e a maior largura da bacia são respectivamente, 15,4 e $7,4 \mathrm{~km}$.

A vazão média anual (1999-2000) foi de 209,4 L s-1 (Moretti, 2001). As maiores médias mensais concentram-se de dezembro a março, correspondendo ao período de cheia e de maior incidência de chuvas na região (Figura 6). Com relação às vazões máximas de pico de cheias, a maior encontrada nestes dois anos foi de $24,8 \mathrm{~m}^{3} \mathrm{~s}^{-1}$ em janeiro de 1999.

Com relação aos resultados das estimativas das vazões pelo estudo de regionalização, observa-se que o valor da vazão média obtida neste método é muito próximo ao valor medido no vertedor em 1999 e 2000, 209,4 $\mathrm{L} \mathrm{s}^{-1}$, é muito próximo do valor da vazão média plurianual encontrada pela regionalização (Tabela 9). Assim, pode-se considerar que os valores calculados pelo método da regionalização estão dentro dos valores esperados para a área de estudo. 


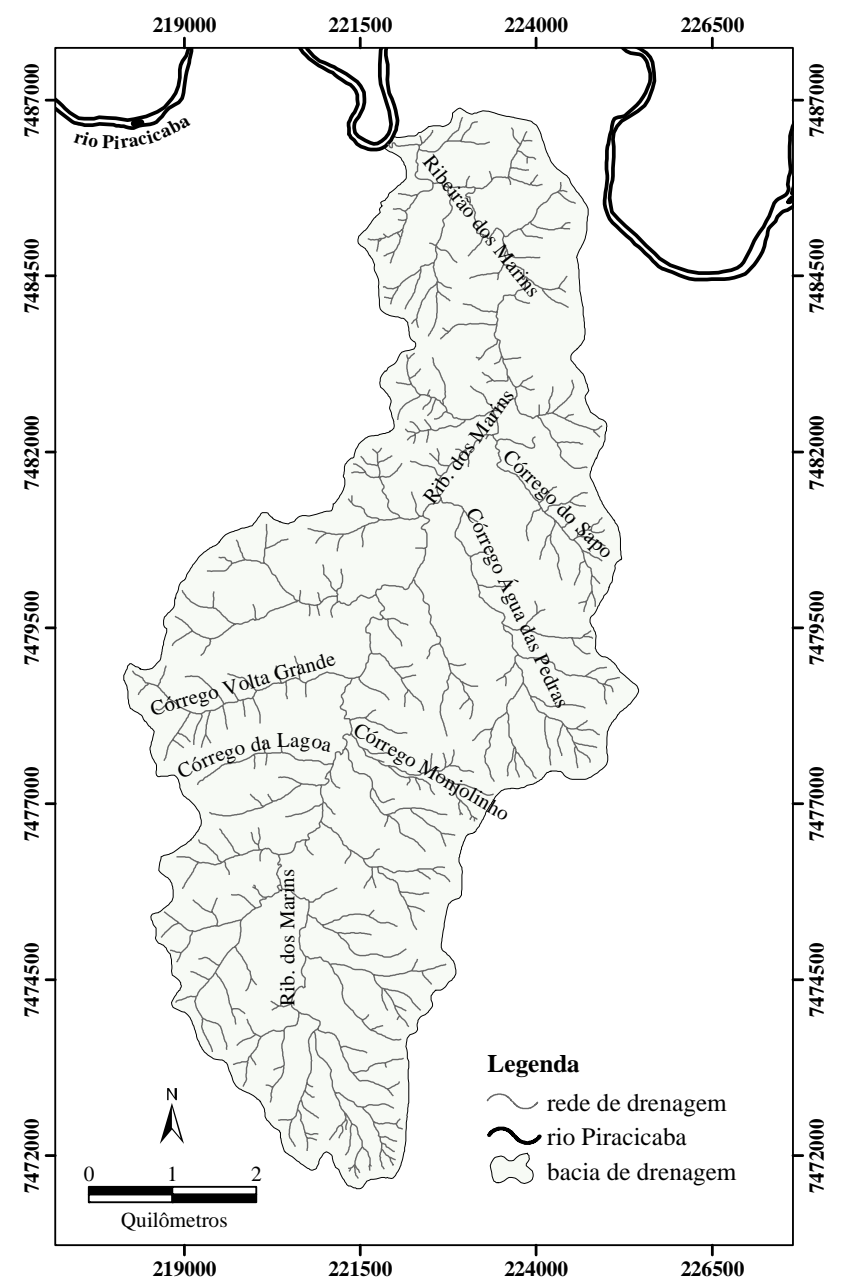

Figura 5 - Rede de drenagem da bacia do ribeirão dos Marins

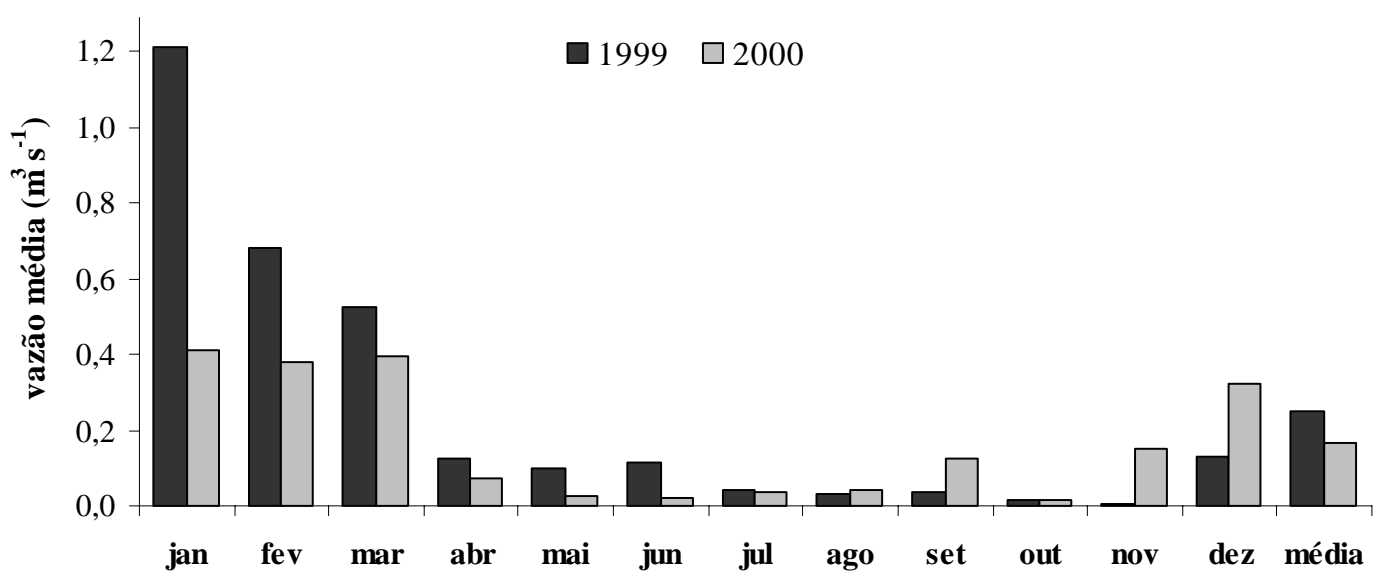

Figura 6 - Vazões médias na bacia do ribeirão dos Marins 
Tabela 9. Valores estimados de vazões pelo método da regionalização no ribeirão dos Marins

\begin{tabular}{lcc}
\hline & $\begin{array}{c}\text { Sub-bacia Monjolinho } \\
\text { (Moretti, 2001) }\end{array}$ & $\begin{array}{c}\text { Bacia dos } \\
\text { Marins }\end{array}$ \\
\hline Precipitação anual média (mm) & 1293,7 & 1338,4 \\
Vazão específica média plurianual $\left(\mathbf{L ~ s}^{\mathbf{- 1}} \mathbf{~ k m}^{-\mathbf{2}}\right)$ & 9,75 & 10,97 \\
Vazão média plurianual $\left(\mathbf{L ~ s}^{\mathbf{- 1}}\right)$ & 213 & 641 \\
$\mathrm{Q}_{7,10}\left(\mathbf{L ~ s}^{\mathbf{- 1}}\right)$ & 48 & 143 \\
$\mathrm{Q}_{95 \%}\left(\mathbf{L ~ s}^{-\mathbf{1}}\right)$ & 77 & 233 \\
\hline
\end{tabular}

De um modo geral, o terreno da área de estudo é relativamente plano e pouco acidentado, com uma altitude média de 529 metros (Figura 7). Nos vales, o menor valor de altitude observado foi 460,4 metros, enquanto nas nascentes a altitude atingiu o valor máximo de 615 metros. Em média, a amplitude na altitude é de apenas 155 metros.

Os valores de declividade variam de 0 a 111,7 \%, com valores médios de 9,1\%. Para melhor visualização das áreas mais acidentadas (Figura 8), foram estabelecidas seis faixas de declividade, conforme as classes utilizadas para a classificação adaptada de capacidade de uso do solo. Como pode ser observado na Tabela 10, a maior parte da área de estudo (42\%) apresenta valores de declividade entre 6 e $12 \%$. A segunda classe dominante é a declividade entre 12 e $20 \%$, compreendendo 22,5 \% da bacia.

Tabela 10. Percentuais das diferentes classes de declividade na bacia dos Marins

\begin{tabular}{cccc}
\hline Classe & Declividade (\%) & Área $\left.\mathbf{( k m}^{\mathbf{2}}\right)$ & Área $\mathbf{( \% )}$ \\
\hline I & $0-3$ & 9,96 & 17,0 \\
II & $3-6$ & 7,27 & 12,4 \\
III & $6-12$ & 24,59 & 42,1 \\
IV & $12-20$ & 13,15 & 22,5 \\
VI & $20-40$ & 3,30 & 5,7 \\
VII & $>40$ & 0,17 & 0,3 \\
Total & & 58,44 & 100,0 \\
\hline
\end{tabular}




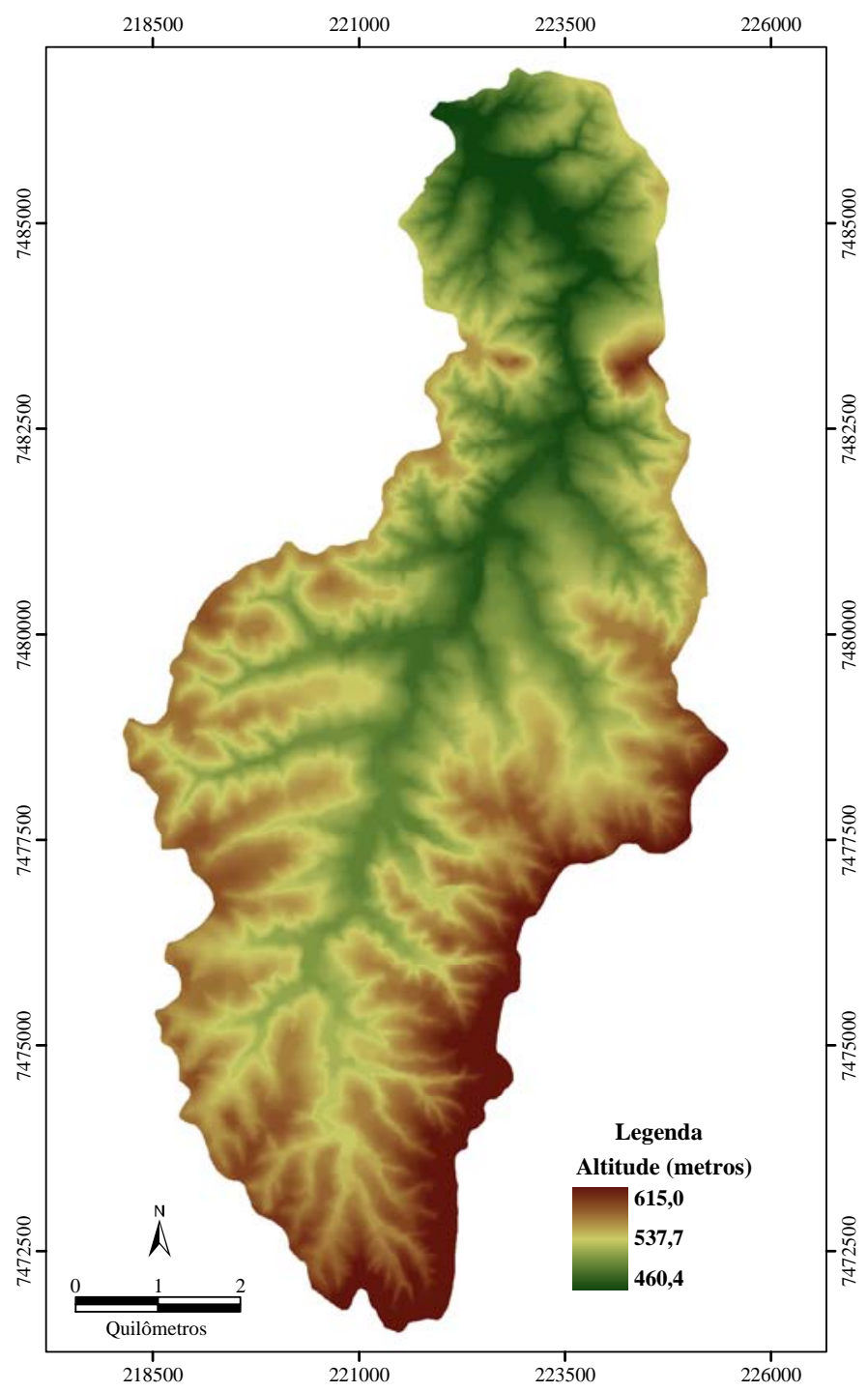

Figura 7 - Modelo Digital de Elevação do Terreno da bacia do ribeirão dos Marins

Em termos de solos, na bacia estudada as unidades predominantes pertencem aos argissolos e neossolos, os quais representam aproximadamente $98 \%$ da área total. O restante da bacia está coberto por pequenas manchas de nitossolo, urbanização, uma pequena área de extração de rochas e latossolo (Tabela 11). Uma descrição mais detalhada do mapa de solos foi realizada por Ranieri (1996), na qual os Cambissolos foram identificados além das unidades apresentadas na Tabela 11. A bacia dos Marins está inserida na bacia sedimentar do Paraná. Ela está localizada na depressão periférica 
paulista, na zona do Médio Tietê. Esta Zona é constituída por sedimentos com área expressiva de intrusões de rochas básicas (Teramoto, 1995 e 2001).

A população da bacia do ribeirão dos Marins estimada em 2000 era de 8009 habitantes, dos quais 6557 (81,9 \%) estavam nos setores da zona urbana e 1452 (18,1 \%) na zona rural. No período de 1991 a 2000 ocorreu um aumento no número de habitantes e na densidade populacional (Tabela 12). Este aumento coincide com o aumento da urbanização observado nos mapas de uso e cobertura do solo, como pode ser observado numa série temporal de fotografias aéreas apresentada na Figura 9.

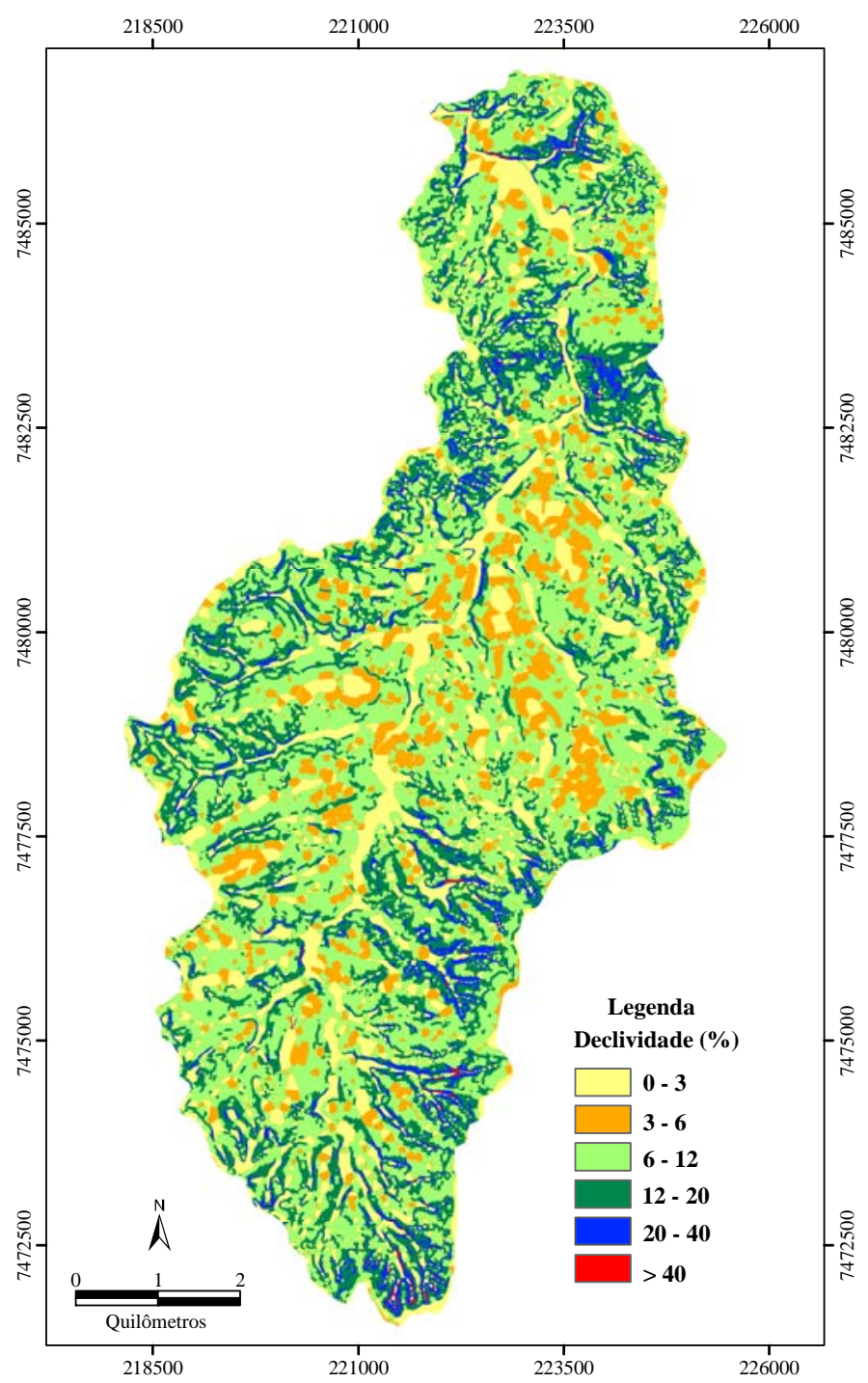

Figura 8 - Declividade (em porcentagem) da bacia do ribeirão dos Marins 
Tabela 11. Percentuais das unidades de solo, na escala semi-detalhada, na bacia do ribeirão dos Marins

\begin{tabular}{llc}
\hline Unidade & Nomenclatura nova (EMBRAPA, 1999) & $\begin{array}{c}\text { Área } \\
\mathbf{( \% )}\end{array}$ \\
\hline LE2+PE & Latossolo Vermelho Distrófico + Argissolo Vermelho & 0,23 \\
LV2 & Latossolo Vermelho-Amarelo Distrófico & 0,11 \\
Li3 & Neossolo Litólico Eutrófico ou Distrófico & 35,61 \\
PV10+Li3+PV9 & Argissolo Vermelho-Amarelo Eutrófico + Neossolo Litólico & 4,79 \\
PV7 & Nutrófico ou Distrófico + Argissolo Amarelo & 37,56 \\
PV7+PV8 & Argissolo Vermelho-Amarelo & 6,25 \\
TE1 & Argissolo Vermelho-Amarelo & 13,65 \\
TE1+Li6 & Nitossolo Vermelho Eutrófico & 0,33 \\
TT1 & Nitossolo Vermelho Eutrófico + Neossolo Litólico Eutrófico & 0,93 \\
Urbanização & Tipos de Terreno: Extração de pedra & 0,06 \\
\hline & & 0,46 \\
\hline
\end{tabular}

Tabela 12. População na bacia do ribeirão dos Marins

\begin{tabular}{lcc}
\hline \multicolumn{1}{c}{ Bacia dos Marins } & $\mathbf{1 9 9 1}$ & $\mathbf{2 0 0 0}$ \\
\hline Pessoas residentes & 4988 & 8009 \\
População setores zona rural & 1369 & 1452 \\
População setores zona urbana & 3619 & 6557 \\
População rural (\%) & 27 & 18 \\
População urbana (\%) & 73 & 82 \\
Densidade populacional (hab km ${ }^{-2}$ ) & 85 & 137 \\
\hline
\end{tabular}



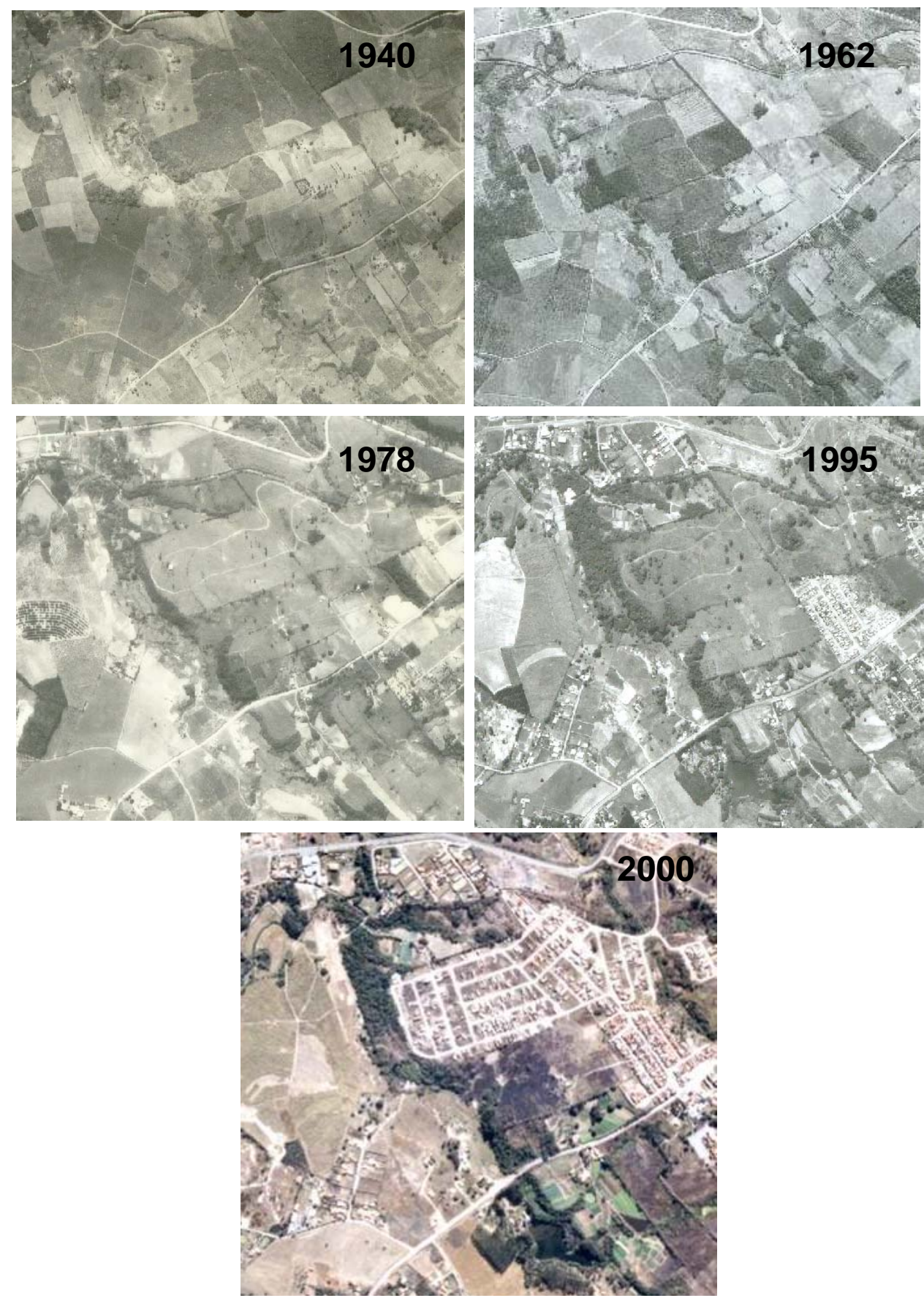

Figura 9 - Fotografias aéreas de 1940, 1962, 1978, 1995 e 2000 mostrando o processo de urbanização de uma área da bacia do ribeirão dos Marins 
Em termos percentuais, pode-se perceber que a maior parte da população da bacia está concentrada na zona urbana e que ocorreu uma mudança na distribuição da população. O percentual da população concentrada na zona urbana era maior em 2000 que em 1991, enquanto na zona rural era maior em 1991 que em 2000. Porém, observase que a população urbana aumentou mais que a rural neste período (Tabela 12). Cabe ressaltar que apesar do limite do perímetro urbano ter sido alterado em 1999, isto não deve ter interferido na análise uma vez que a população urbana e rural estimada foi calculada com base na divisão do IBGE de setores urbanos e rurais. Como os setores são apenas subdivididos com o passar dos anos, o perímetro urbano considerado pelo IBGE foi praticamente o mesmo nestes anos na região da bacia em estudo.

Segundo o Levantamento Censitário de Unidades de Produção Agropecuária (LUPA), realizado a partir de 1995 através da aplicação de um questionário aos produtores rurais pela Coordenadoria de Assistência Técnica Integral (CATI), as propriedades do município de Piracicaba encontram-se estratificadas conforme a Tabela 13. Predominam no município as pequenas e médias propriedades rurais, das quais cerca de 300 estão localizadas na bacia hidrográfica do ribeirão dos Marins (CATI, 2001).

Tabela 13. Estratificação das propriedades do município de Piracicaba

\begin{tabular}{lccc}
\hline \multicolumn{1}{c}{ PRINCIPAL } & $\begin{array}{c}\mathbf{N}^{\mathbf{o}} \text { de proprietários } \\
\text { em áreas com até } \\
\mathbf{5 0} \text { ha }\end{array}$ & $\begin{array}{c}\mathbf{N}^{\mathbf{0}} \text { de proprietários em } \\
\text { áreas maiores que } \\
\mathbf{5 0} \text { ha até } \mathbf{2 0 0} \text { ha }\end{array}$ & $\begin{array}{c}\mathbf{N}^{\mathbf{0}} \text { de proprietários } \\
\text { em áreas maiores } \\
\text { que 200 ha }\end{array}$ \\
\hline AGROPECUÁRIA & 1900 & 357 & 128 \\
OUTRAS & 75 & - & - \\
TOTAL & 1975 & 357 & 128 \\
$\%$ & 80,3 & 14,5 & 5,2 \\
\hline
\end{tabular}

FONTE: Casa da Agricultura de Piracicaba, 2001.

Um levantamento sócio-econômico junto aos produtores da bacia (proprietários, arrendatários, meeiros etc), realizado pela CATI, revelou que as principais atividades econômicas na bacia estão relacionadas com a agropecuária. Com exceção da cana-deaçúcar, pastagem, milho, hortaliças, sorgo-vassoura e banana, as demais explorações 
agrícolas são para consumo próprio (Tabela 14). A exploração pecuária na área refere-se à bovinocultura, avicultura, suinocultura, ovinocultura e caprinocultura conforme a Tabela 15. A maioria das explorações é de forma extensiva, com exceção da avicultura.

Tabela 14. Exploração agrícola na bacia do ribeirão dos Marins

\begin{tabular}{lc}
\hline Exploração Agrícola & N $^{\mathbf{0}}$ Produtores \\
\hline Cana-de-açúcar & 171 \\
Pastagem & 190 \\
Hortaliças & 37 \\
Milho & 30 \\
Eucalipto & 30 \\
Pomar doméstico & 31 \\
Sorgo vassoura & 8 \\
Napier & 13 \\
Banana & 4 \\
Coco & 1 \\
Arroz & 2 \\
Citros & 2 \\
Mandioca & 2 \\
Maracujá & 1 \\
Feijão & 2 \\
Manga & 1 \\
\hline
\end{tabular}

Tabela 15. Pecuária na bacia do ribeirão dos Marins

\begin{tabular}{lcc}
\hline Exploração Pecuária & Rebanho (cabeça) & $\mathbf{N}^{\mathbf{0}}$ Produtores \\
\hline Bovinocultura mista & 1384 & 85 \\
Bovinocultura de leite & 207 & 7 \\
Bovinocultura de corte & 91 & 3 \\
Avicultura de corte & 41.300 & 3 \\
Suinocuotura & 141 & 11 \\
Ovinocultura & 91 & 3 \\
Caprinocultura & 8 & 2 \\
\hline
\end{tabular}




\section{Produtores de hortaliças, outorgas e aspectos sanitários}

Aproximadamente $80 \%$ das hortaliças produzidas em área rural de Piracicaba encontram-se na bacia dos Marins, as quais abastecem aproximadamente 30 municípios da região através do CEASA (SEMA, 2003). Em levantamento junto aos produtores de hortaliças da bacia, realizado pela Secretaria de Agricultura e Abastecimento de Piracicaba junto a 34 produtores rurais, foi observado que a água utilizada para irrigação por grande parte dos produtores de hortaliças $(58,8 \%)$ é proveniente do ribeirão dos Marins e de alguns de seus afluentes, como o ribeirão das Pedras (Figura 10). Se incluirmos, além destes, também os produtores que utilizam água de açudes ou lagos, este percentual se eleva para 88,2 \% dos entrevistados. Cabe salientar que muitos produtores utilizam água de mais de uma fonte. Com base nas fontes de água para a irrigação, podemos constatar que existe um risco elevado de contaminação da produção de uma parte considerável das hortas, as quais sofrem grande influencia da qualidade da água da bacia. A localização dos produtores de hortaliças, que utilizam e que não utilizam água de ribeirão ou córrego para irrigação, pode ser visualizada na Figura 11.

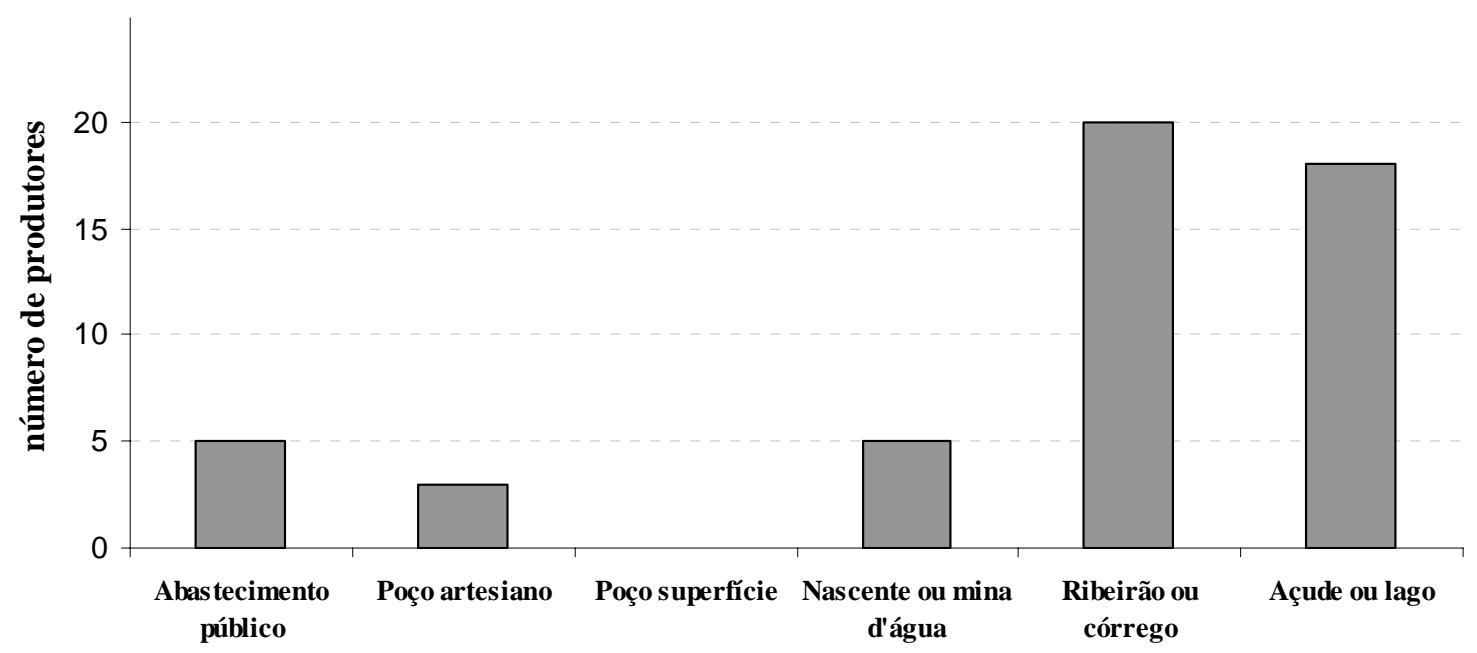

Figura 10 - Origem da água utilizada na irrigação das hortaliças na bacia do ribeirão dos Marins 


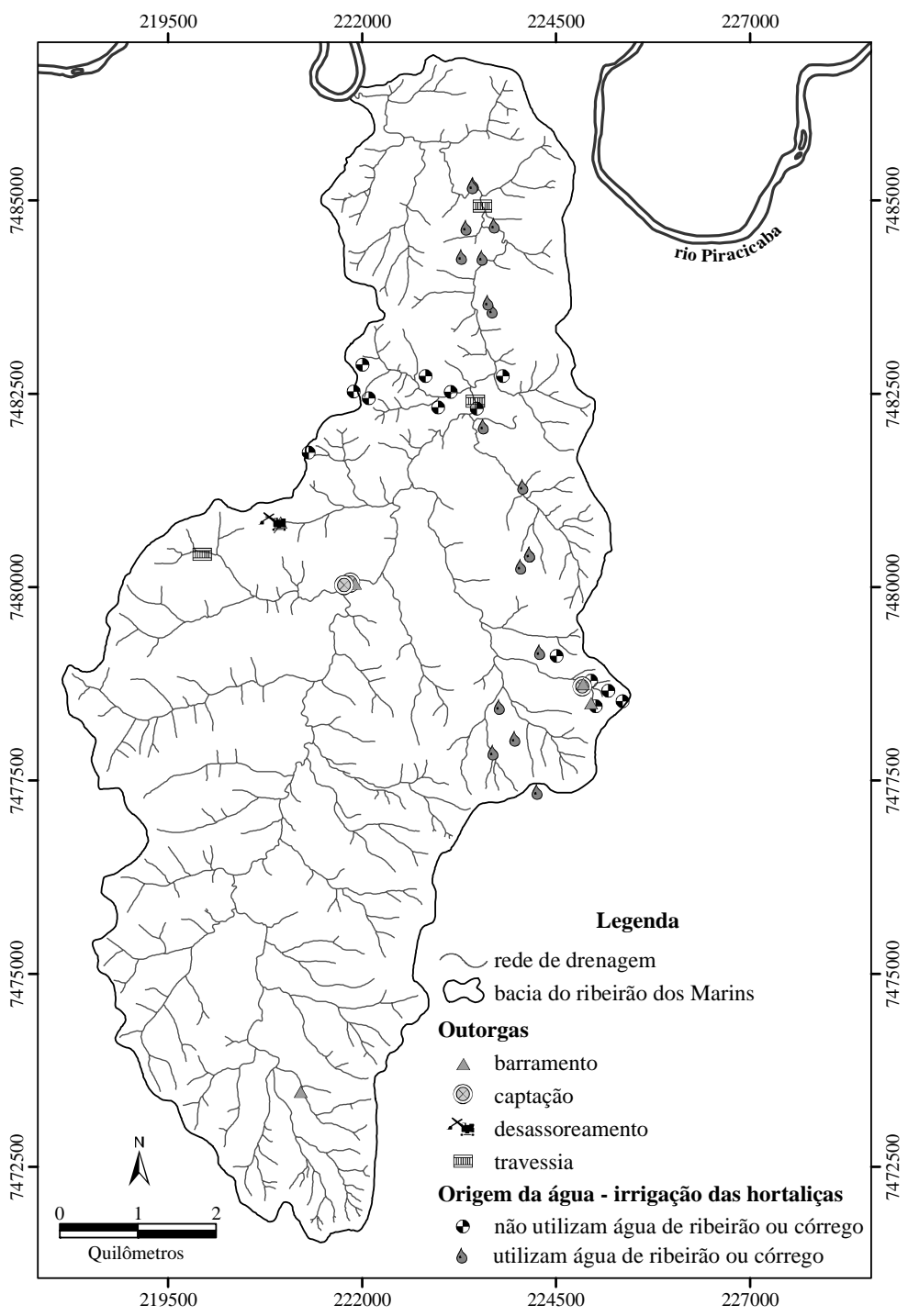

Figura 11 - Localização das outorgas concedidas e dos produtores de hortaliças identificando a origem da água utilizada para irrigação na bacia do ribeirão dos Marins

As propriedades localizadas mais próximas a zona urbana, que utilizam água do abastecimento público, apresentam pequenas áreas de cultivo. Cinco produtores utilizam água de abastecimento público. Porém, apenas três não possuem outra fonte de água. Uma outra fonte considerada são poços artesianos. Porém, apenas três produtores mencionaram usar essa fonte, sendo esta de uso alternativo para a irrigação das hortaliças pois água de ribeirões ou córregos também é utilizada por estes. Com relação a poços de superfície, nenhum dos produtores mencionaram esta fonte. 
Uma das principais fontes de contaminação dos mananciais é o lançamento indiscriminado dos resíduos orgânicos, provenientes da falta de saneamento básico dos bairros pertencentes à bacia do ribeirão dos Marins. Outro fator agravante é a contaminação por insumos agrícolas como adubos e defensivos, que são carreados pelas águas das chuvas para os cursos d’água. A presença do aterro sanitário instalado próximo a um dos afluentes dos Marins (ribeirão das Pedras) é uma fonte de contaminação. A criação intensiva de gado existente à montante do ribeirão dos Marins, também contribui para a contaminação do manancial devido ao transporte de seus excrementos pela água de chuvas. A soma desses fatores vem comprometendo significativamente a qualidade da água do ribeirão dos Marins e dos produtos originados pela mesma (SEMA, 2003).

A coleta de lixo é precária na zona rural. Apenas 41,2 \% dos produtores possuem coleta de lixo, parte dos produtores queimam, enterram ou depositam seus lixos em locais indevidos como beira de estradas, próximo ou mesmo dentro dos ribeirões. Não existia rede coletora de esgoto em nenhuma das propriedades entrevistadas. Todos os produtores rurais recolhem seus esgotos em fossas, de acordo com os questionários respondidos, apenas três não possuem fossa por ninguém morar no local.

As hortaliças produzidas na bacia do ribeirão dos Marins abastecem desde pequenas quitandas a grandes supermercados, não apenas em Piracicaba mas também em outros municípios da região, via Companhia de Entrepostos e Armazéns Gerais do Estado de São Paulo - CEAGESP/CEASA-Piracicaba.

As embalagens dos defensivos não são destinadas de maneira adequada e nem são encaminhadas para locais de coleta, pela maioria dos produtores. Embora os produtores saibam produzir as hortaliças, eles desconhecem ou não praticam atividades de higienização do produto, bem como, de controle de pragas. Apenas quatro produtores rurais não utilizam defensivos agrícolas, os quais praticam agricultura orgânica com controle fitossanitário (SEMA, 2003).

Alguns agricultores, por falta de informação, entendimento e fiscalização, erroneamente aumentam as doses dos defensivos agrícolas, para combater o aumento de pragas e doenças proporcionado pela alteração do ecossistema, práticas inadequadas e 
retirada de vegetação natural, e conseqüente eliminação dos predadores naturais. Estes produtos químicos aplicados inadequadamente, acabam sendo transportados pelas águas das chuvas para dentro dos ribeirões e/ou açudes, contaminando desta forma, a água utilizada para irrigação das hortaliças (SEMA, 2003).

Conforme especificado na Lei Estadual 7.663 de 30/12/1991 e no Decreto Estadual 41.258 de 31/10/1996, o qual aprova o regulamento dos artigos $9^{\circ}$ a 13 da referida lei, qualquer pessoa necessita de uma outorga para fazer uso das águas de um rio, lago ou águas subterrâneas no estado de São Paulo. Essa autorização, concessão ou licença (Outorga) é dada pelo Departamento de Águas e Energia Elétrica - DAEE e é necessária para:

- Implantação de qualquer empreendimento que possa demandar a utilização de recursos hídricos, superficiais ou subterrâneos;

- Execução de obras ou serviços que possa alterar o regime, a quantidade e a qualidade desses mesmos recursos;

- Execução de obras para extração de águas subterrâneas;

- Derivação de água do seu curso ou depósito, superficial ou subterrâneo;

- Lançamento de efluentes nos corpos d'água.

Na bacia dos Marins, conforme lista dos usuários outorgados pelo DAEE de 29/07/2003, existem 12 licenças (Figura 11), que somados retiram 9,5 $\mathrm{m}^{3} \mathrm{~h}^{-1}$ do ribeirão.

O esgoto gerado por alguns bairros da região é lançado no trecho final do ribeirão dos Marins. Em 2002, o Fundo Estadual de Recursos Hídricos (FEHIDRO) destinou uma verba ao Serviço Municipal de Água e Esgoto (SEMAE), a qual está sendo aplicada na construção de duas estações elevatórias para desviar o esgoto para o coletor tronco do ribeirão do Enxofre, levando-o para o rio Piracicaba. Segundo o SEMAE, estas duas elevatórias na região conhecida como Santo Antônio e uma no bairro Glebas Califórnia estão em construção. Para o projeto das estações elevatórias do Santo Antônio a população estimada em 2003 foi de 5.400 habitantes, a qual estaria gerando, em média, 17,6 L s s${ }^{-1}$ de esgoto. Para o final do plano, em 2015, a população estimada foi de 8.300 habitantes gerando em média 27,0 L s${ }^{-1}$ de esgoto. Já para a estação elevatória das Glebas Califórnia a população estimada em 2003 foi de 4.300 pessoas e a vazão de 
esgoto de 13,9 L s s . Para 2015 uma população de 6.500 habitantes e uma vazão de $21 \mathrm{~L}$ $\mathrm{s}^{-1}$ de esgoto foi estimada.

Com base nestes valores, pode-se estimar que, aproximadamente, 31,5 $\mathrm{L} \mathrm{s}^{-1}$ de esgoto são despejados no ribeirão dos Marins atualmente, sem nenhum tratamento. Considerando a existência de diversas hortas na bacia que utilizam água do ribeirão para irrigação, a construção destas estações elevatórias é de extrema importância para a qualidade da água do mesmo. Contudo, cabe ressaltar que todo esgoto gerado apenas está sendo desviado e lançado no rio Piracicaba e não sendo tratado. O esgoto da elevatória das Glebas Califórnia talvez seja destinado a uma antiga fossa, que poderá ser reativada e reformulada para funcionar como um sistema de tratamento. Uma vez que as estações elevatórias já estão sendo construídas, pode-se considerar que alguma atitude já vem sendo tomada para amenizar a situação crítica de poluição em que essa região se encontra.

Na Figura 12 podemos observar a adutora referente às elevatórias do Jardim Santo Antônio e os pontos de lançamento de esgoto (Ruffolo, 2003), os quais concentram-se próximos à rede coletora de esgoto do SEMAE e às elevatórias que estão sendo construídas. Podemos notar que a situação realmente é crítica, uma vez que perto da região dos pontos de lançamento de esgoto existem vários produtores de hortaliças sendo que muitos deles utilizam água do ribeirão para irrigação.

Outro aspecto importante é o grande número de fossas na bacia (Figura 13), as quais foram identificadas por Ruffolo (2003) e pela SEMA (2003). As fossas podem ser um fator favorável ou não para a manutenção da qualidade ambiental. Estas, quando bem projetadas minimizam o efeito prejudicial do esgoto que seria lançado in natura no corpo d’água, uma vez que reduzem a carga orgânica do esgoto a níveis aceitáveis em algumas condições. Contudo, se esta não for bem projetada, o tratamento pode ser ineficiente e ser fonte de contaminação. É interessante notar que todas estas atividades estão concentradas nas porções central e final da bacia. 


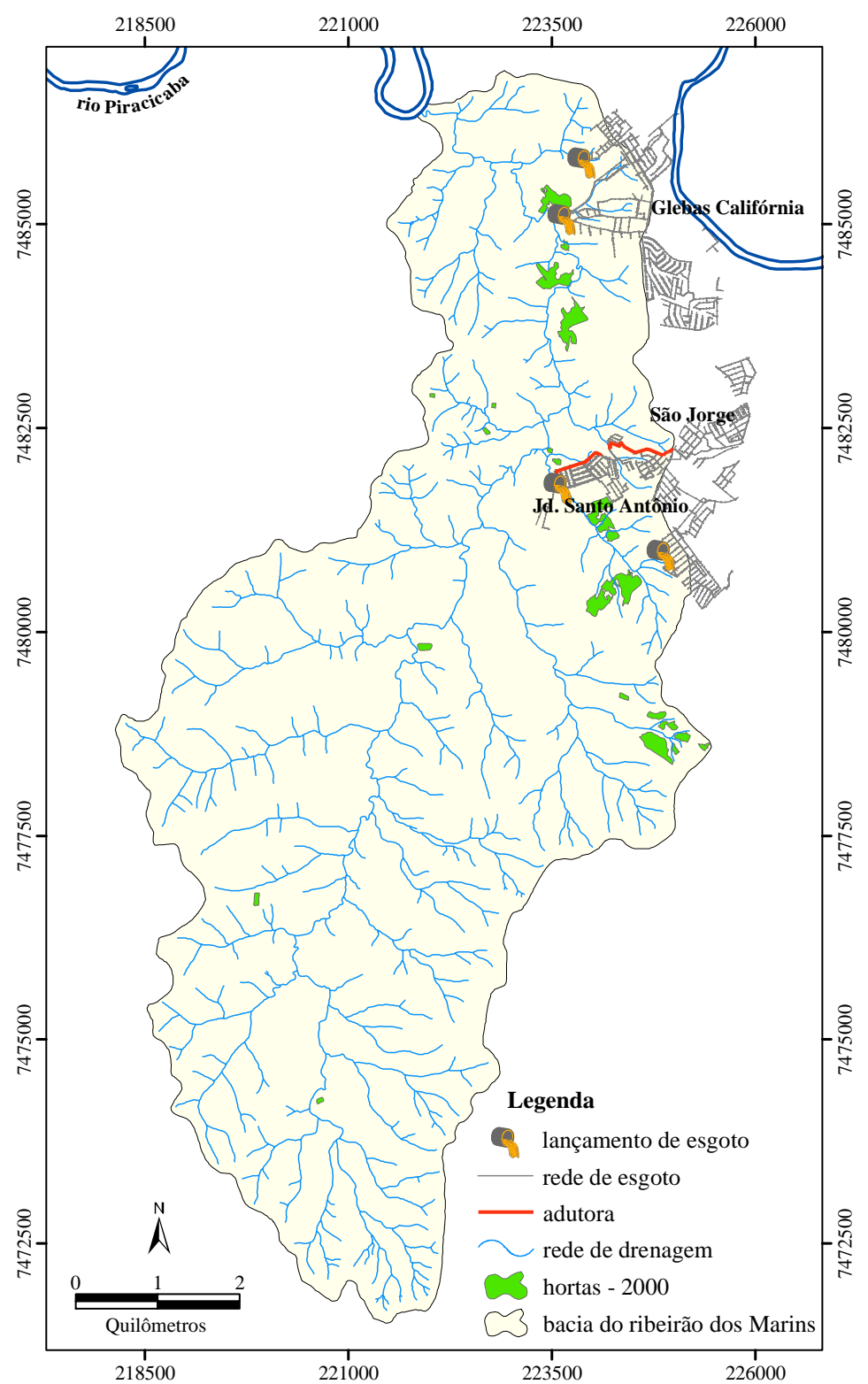

Figura 12 - Localização de pontos de lançamento de esgoto, rede coletora de esgoto, estações elevatórias e hortas referentes ao mapa de uso e cobertura do solo de 2000 na bacia do ribeirão dos Marins 


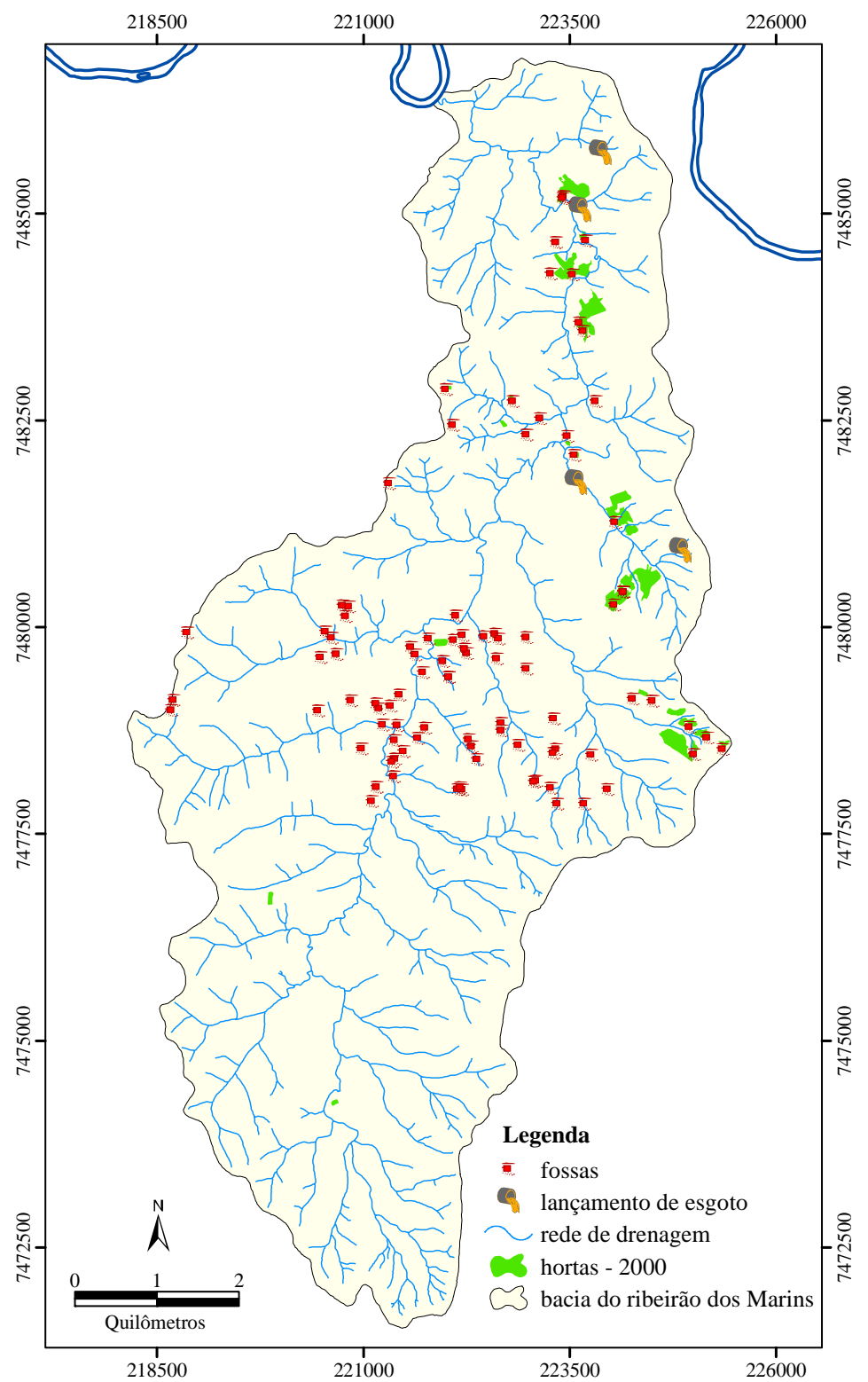

Figura 13 - Localização das fossas, pontos de lançamento de esgoto e hortas na bacia do ribeirão dos Marins

\section{Indústrias e empreendimentos}

Na bacia dos Marins podemos encontrar olarias, serrarias, granjas, reciclagem de plástico, indústria de herbicidas, indústria e comércio de metais, aterro sanitário, dentre outros. Além destes, cabe ressaltar, a presença de uma mini usina de beneficiamento de leite, a qual obteve a licença de instalação, já foi construída, e apenas aguarda a licença de funcionamento. Informações a respeito das indústrias mais relevantes para o 
propósito deste trabalho foram obtidas junto a CETESB através da leitura de processos que foram localizados para cada empreendimento. Essas indústrias constituem possíveis fontes de poluição e contaminação, fato este que pode ser constatado pelo histórico destas junto ao órgão de licenciamento, fiscalização e monitoramento ambiental.

A mini usina de beneficiamento de leite do município de Piracicaba, da Cooperativa dos Produtores de Leite de Piracicaba e Região - COPLEPI, situa-se no bairro São Jorge. Ela produzirá uma quantidade média anual de 3.650 .000 litros de leite integral pasteurizado. Uma vazão média de consumo de água de $60 \mathrm{~m}^{3}$ dia $^{-1}$ será obtida da rede de água pública. O efluente líquido gerado corresponde, basicamente, à água utilizada para a lavagem de equipamentos da usina, com despejo de $60 \mathrm{~m}^{3}$ por dia. Um sistema de tratamento de efluentes será construído para tratar os despejos, os quais deverão conter alto teor de matéria orgânica, gordura e, eventualmente, de cloretos. Segundo os processos da CETESB, além dos efluentes, existe o potencial poluidor do ar, devido à operação de uma caldeira a óleo diesel e do solo, devido aos resíduos de embalagem, e do sistema de tratamento a ser implantado. Na licença de instalação, foram estabelecidas condições referentes à necessidade de tratamento de efluentes, a proibição do lançamento de efluentes líquidos e lodo em galeria de água pluvial ou em via pública. Foi determinado, ainda, que o lodo deverá ser seco em leitos de secagem ou compartimento similar e disposto em plantas aprovadas pela CETESB.

A Agritec Indústria Brasileira de Herbicidas situa-se no bairro Glebas Califórnia, está devidamente licenciada na CETESB, possui licença de funcionamento, plano de ação emergencial e de gerenciamento de riscos. As águas de lavagem de equipamentos são reutilizadas no processo e não há geração de efluentes líquidos. Os efluentes líquidos sanitários são tratados em fossa séptica e este efluente é lançado em um córrego afluente do ribeirão dos Marins (CETESB - Processos referentes a Agritec).

A Catálise Indústria e Comércio de Metais situa-se no bairro Monjolinho, possui a licença de funcionamento e não gera efluentes líquidos industriais. No final de 2002, a empresa foi multada por operar fontes de poluição do ar (secador, moinhos, peneiras e embaladoras) desprovidas de sistemas de ventilação local exaustora e equipamento de controle de poluição, causando inconvenientes ao bem estar da população pela emissão 
de material particulado para a atmosfera, visivelmente perceptível. Em 2003, a firma não tinha atendido à exigência técnica da CETESB, houve registro de reclamação da vizinhança devido a incômodos provocados pela emissão de odor e material particulado e na vistoria era visível a emissão de poeira proveniente das atividades produtivas. Assim, a empresa foi multada novamente (CETESB - Processos referente à Catálise). Em 2001, a empresa foi multada devido à poluição do solo por infiltração de efluente oleoso oriundo de vazamentos dos compressores e por emitir ruído acima dos níveis estabelecidos pela legislação. Posteriormente, a CETESB foi notificada acerca de enterramento de grande quantidade de resíduos em determinados locais na área da fábrica. Em uma vistoria realizada foram encontrados enterrados resíduos a granel ou em tambores constituídos por óxidos de níquel, cobre, vanádio, ferro e alumínio na forma de catalisadores exauridos e a fábrica foi multada. Um plano de recuperação ambiental da área foi apresentado. Os resíduos foram removidos, mas não foram estocados conforme exigências feitas pela CETESB. Assim, a empresa foi multada em 2002 novamente por acumular resíduos sólidos perigosos direto no solo de maneira inadequada.

Em 2003, a CETESB coletou amostras de água do ribeirão que cruza a propriedade da firma e do solo as margens do ribeirão. A qualidade da água do córrego não estava alterada. Porém no solo foram encontrados focos de contaminação por metais nos dois pontos à margem do córrego que cruza a propriedade. Foram encontradas concentrações de bário, chumbo, cobre, cromo e níquel superiores aos valores de intervenção para áreas industriais e concentrações de cádmio e zinco superiores aos valores de alerta. A firma apresentou o plano de recuperação ambiental da área e solicitou um CADRI (Certificado de Aprovação para Destinação de Resíduos Industriais) para dispor os resíduos em um aterro industrial. O relatório referente à recuperação ambiental não foi satisfatório e a classificação dos resíduos por parte da firma e a caracterização da área afetada pelo depósito irregular de resíduos ainda não foi apresentada. A definição sobre a destinação final dos resíduos não ocorreu devido à classificação dos resíduos não ter sido entregue. A empresa foi multada novamente por acumular resíduos sólidos perigosos direto no solo e causar a contaminação do solo com metais. 
O Aterro Sanitário Pau Queimado localiza-se no Sítio Pau Queimado, entre os bairros Pau Queimado e Campestre (Figura 14). A área está contida na sub-bacia do córrego Água das Pedras, afluente do ribeirão dos Marins. A área do atual Aterro possui um histórico que deve ser considerado. Durante 13 anos, os resíduos sólidos gerados no município de Piracicaba foram dispostos a céu aberto, sem qualquer controle ou tratamento, em uma área de $90.000 \mathrm{~m}^{2}$ na zona rural do município. Diante desta situação, a Prefeitura de Piracicaba propôs um projeto para continuidade de disposição de resíduos sólidos do Município na área, só que de uma forma controlada, com o objetivo de introduzir mecanismos e ações emergenciais para a recuperação de uma extensa área degradada (CETESB - Processos referentes ao Aterro Sanitário do Pau Queimado).

Os resíduos que foram dispostos durante treze anos (1977 a 1989) na área eram oriundos das residências e domicílios, estabelecimentos comerciais e industriais, serviços de saúde (hospitais, farmácias, ambulatórios etc.), serviço de varrição e capina, ou seja, quase a totalidade dos resíduos gerados no município de Piracicaba. Em função da origem, os resíduos dispostos na área constituem-se de uma massa heterogênea e complexa, podendo ser encontrados resíduos perigosos dentre outros, segundo a ABNT, NBR 10.004, resíduos Classe I, II e III. Cabe ressaltar, a presença de resíduos hospitalares e industriais Classe I, considerados perigosos, os quais merecem atenções especiais, justificando, inclusive, a interdição da prática de co-dispor tais resíduos naquela área.

Com base na evolução demográfica do município de Piracicaba entre 1977 e 1989 e de valores teóricos da produção de lixo per capta de 0,5 kg por habitante por dia, estimou-se em 563.560 ton a quantidade de lixo disposta nesse período (CETESB Processos referentes ao Aterro Sanitário do Pau Queimado).

No entorno do aterro observa-se a existência de córregos e ribeirões muito próximos a área deste, sendo esta servida por algumas nascentes, existindo inclusive, nos limites, uma lagoa artificial que vinha sendo utilizada para fins agrícolas. A existência de uma nascente nas proximidades, contribui para a formação de líquidos percolados no aterro além do volume de chorume que é gerado naturalmente pelos resíduos em decomposição. 


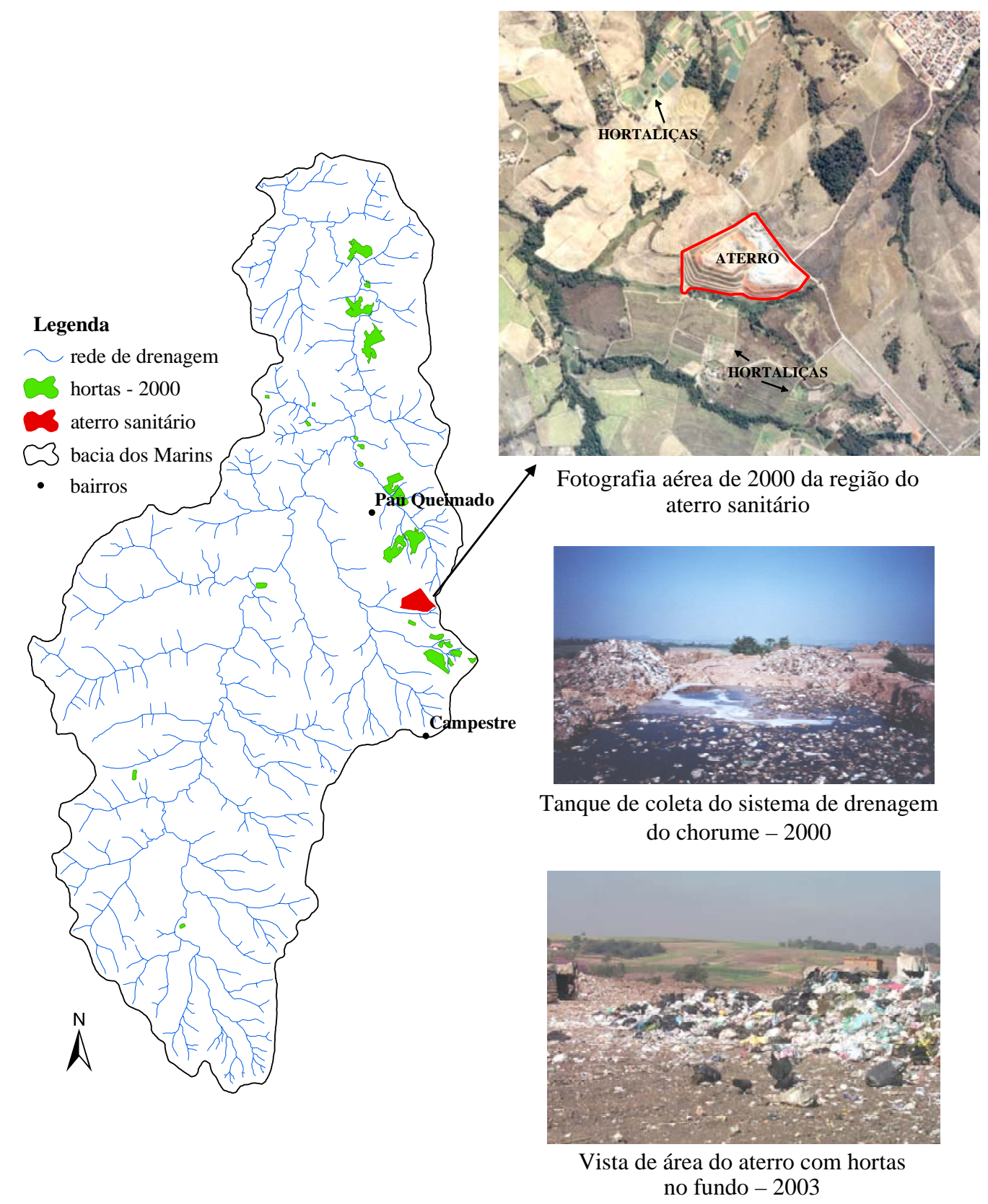

Figura 14 - Localização do aterro sanitário, visualização das hortas levantadas por fotografias aéreas de 2000 e fotografias do aterro sanitário na bacia do ribeirão dos Marins

O sistema de tratamento de chorume adotado para o aterro sanitário de Piracicaba considera a recirculação do mesmo, previamente tratado em processos 
biológicos anaeróbios, através de utilização de reatores não convencionais (filtro anaeróbio, reator de “manta de lodo” etc.), incorporando-o novamente no aterro. Quando se efetua o processo de recirculação, ocorre um aproveitamento da própria capacidade que os aterros dispõem para tratamento da fase líquida, com todos os drenos de gases e líquidos funcionando como verdadeiros “filtros anaeróbios”, isolados termicamente pela massa de resíduos. O processo de tratamento biológico implantado no aterro de Piracicaba consiste de um reator biológico denominado filtro anaeróbio de leito fixo.

A operação dos reatores biológicos foi iniciada em agosto de 1992 e os resultados das análises do chorume, nesta data antes e após o tratamento, indicaram uma redução dos sólidos, da Demanda Química de Oxigênio (DQO), da (Demanda Bioquímica de Oxigênio) DBO e do nitrogênio, dentre outros parâmetros. Contudo, cabe ressaltar que muitos imprevistos ocorreram e isso não ocorreu durante todo período de operação dos reatores.

Em 1993, ensaios geotécnicos foram realizados no aterro. As sondagens revelaram que o nível d’água se encontrava, na maior parte das perfurações, em profundidade menores que a base do aterro sanitário. Assim, as camadas de lixo estavam em contato direto com as águas subterrâneas, contrariando o que é estabelecido pelas normas que tratam da implantação e operação de aterros de resíduos não perigosos e aterros sanitários.

Em maio de 1996 foram realizadas análises do chorume, das águas superficiais e subterrâneas. No aterro existem quatro poços piezométricos para monitoramento da água subterrânea. Os resultados das análises desses poços mostraram que nos quatro pontos de amostragem as concentrações de manganês encontradas são superiores aos valores máximos permissíveis estabelecidos pela Portaria do Ministério da Saúde $n^{0} 1.469$ de 29/12/2000 como padrão de potabilidade da água destinada ao consumo humano. Para a análise do chorume, amostras da água retida nas caixas de contenção foram coletadas. Conforme comparação dos resultados dessas análises com o artigo 18 do Decreto $\mathrm{n}^{\circ}$ 8.468 de 8/09/76, que estabelece condições para o lançamento de efluentes nas coleções de água, as concentrações de DBO encontradas foram superiores a concentração máxima estabelecida para o lançamento de efluentes. Valores elevados para o parâmetro DQO 
também foram constatados. Quanto as amostras das águas superficiais, os pontos de coleta localizam-se a montante e a jusante do ribeirão das Pedras e a montante e a jusante do ribeirão dos Marins. Cabe ressaltar a presença de coliformes totais na maioria dos pontos amostrados (Tabela 16).

Tabela 16. Análise das águas superficiais na bacia do ribeirão dos Marins

\begin{tabular}{|c|c|c|c|c|}
\hline Determinações & $\begin{array}{c}\text { Montante Rib. } \\
\text { das Pedras }\end{array}$ & $\begin{array}{c}\text { Jusante Rib. } \\
\text { das Pedras }\end{array}$ & $\begin{array}{c}\text { Montante Rib. } \\
\text { dos Marins }\end{array}$ & $\begin{array}{c}\text { Jusante Rib. } \\
\text { dos Marins }\end{array}$ \\
\hline $\mathrm{pH}$ & 7,5 & 7,9 & 7,9 & 7,6 \\
\hline $\mathrm{DQO}\left(\mathrm{mg} \mathrm{O}_{2} \mathrm{~L}^{-1}\right)$ & 33 & 61 & 24 & 25 \\
\hline $\mathrm{DBO}_{5}\left(\mathrm{mg} \mathrm{O}_{2} \mathrm{~L}^{-1}\right)$ & n.d. & n.d. & n.d. & n.d. \\
\hline Condutividade $\left(\mu \mathrm{S} \mathrm{cm}^{-3}\right)$ & 200 & 545 & 232 & 307 \\
\hline Cloretos (mg L ${ }^{-1}$ ) & 4,19 & 45,2 & 4,2 & 11,3 \\
\hline Índice de Fenóis (mg L ${ }^{-1}$ ) & n.d. & n.d. & n.d. & n.d. \\
\hline Cobre $\left(m g L^{-1}\right)$ & n.d. & n.d. & n.d. & n.d. \\
\hline Crômio Total (mg L $\left.{ }^{-1}\right)$ & 0,11 & n.d. & n.d. & n.d. \\
\hline Crômio VI (mg L $\left.{ }^{-1}\right)$ & n.d. & n.d. & n.d. & n.d. \\
\hline Alumínio (mg L ${ }^{-1}$ ) & n.d. & 0,61 & n.d. & n.d. \\
\hline Bário (mg L $\left.{ }^{-1}\right)$ & n.d. & n.d. & n.d. & n.d. \\
\hline Oxigênio Dissolvido $\left(\mathrm{mg} \mathrm{L}^{-1}\right)$ & 7,7 & 7,6 & 8,7 & 7,0 \\
\hline Coliformes Totais por $100 \mathrm{~mL}$ & 500 & 900 & 100 & 0 \\
\hline Coliformes Fecais por $100 \mathrm{~mL}$ & 0 & 0 & 0 & 0 \\
\hline
\end{tabular}

n.d. = não detectado, limites de detecção:

$\mathrm{DQO}=5 \mathrm{mg} \mathrm{O}_{2} \mathrm{~L}^{-1}$; DBO $=1,0 \mathrm{mg} \mathrm{O}_{2} \mathrm{~L}^{-1}$; Cloreto $=0,5 \mathrm{mg} \mathrm{L}^{-1}$; Fenóis = 0,005 $\mathrm{mg} \mathrm{L}^{-1}$; Cobre $=0,03 \mathrm{mg} \mathrm{L}^{-1}$; Crômio Total $=0,1 \mathrm{mg} \mathrm{L}^{-1}$; Crômio $(\mathrm{VI})=0,03 \mathrm{mg} \mathrm{L}^{-1}$; Alumínio = 0,05 $\mathrm{mg} \mathrm{L}^{-1}$; Bário $=0,3 \mathrm{mg} \mathrm{L}^{-1}$.

FONTE: CETESB - Processo 0267/96

Podemos observar um aumento nos valores dos parâmetros DQO, condutividade e cloretos entre os pontos a montante e a jusante do ribeirão das Pedras, o que mostra uma possível interferência do aterro nos parâmetros analisados.

A administração municipal responsável pelo aterro recebeu diversas advertências e multas da CETESB, principalmente a partir de 1998. Os relatórios de inspeção da 
CETESB mostram diversas irregularidades, acidentes e negligências que acabaram por prejudicar os recursos hídricos da região. Os principais acontecimentos são apresentados na Tabela 17, a qual apresenta informações retiradas do processo do aterro na CETESB.

Tabela 17. Impactos ocasionados pelo aterro na bacia do ribeirão dos Marins

\begin{tabular}{|c|c|c|}
\hline Data & Penalidade & Motivo \\
\hline Agosto e Outubro 1998 & Advertência & $\begin{array}{l}\text { Lançamento de chorume no corpo hídrico, alterando } \\
\text { concentração do parâmetro DBO. }\end{array}$ \\
\hline Agosto 1999 & Advertência & $\begin{array}{l}\text { Negligências na operação do chorume causando } \\
\text { impacto negativo no ribeirão das Pedras, ocorreu o } \\
\text { desenquadramento do corpo hídrico receptor. }\end{array}$ \\
\hline Novembro 1999 & - & $\begin{array}{l}\text { Análises realizadas mostraram alteração do OD e } \\
\text { DBO nos Ribeirões Água das Pedras e dos Marins }\end{array}$ \\
\hline Maio 2000 & - & $\begin{array}{l}\text { Ponto de vazamento significativo de chorume, com } \\
\text { lançamento para o ribeirão das Pedras, estava em } \\
\text { manutenção. }\end{array}$ \\
\hline Janeiro 2001 & Advertência & $\begin{array}{l}\text { Lançamento de chorume “in natura” nos cursos } \\
\text { hídricos causando o desenquadramento da classe } \\
\text { destes quanto aos padrões de DBO e DQO. }\end{array}$ \\
\hline Abril 2002 & Multa & $\begin{array}{l}\text { Ter implantado e estar dispondo resíduos sólidos } \\
\text { em área alvo de ampliação sem as devidas } \\
\text { licenças da CETESB, e ter alterado a área de } \\
\text { transbordo para o topo do maciço já selado sem } \\
\text { licença. }\end{array}$ \\
\hline Novembro 2002 & - & $\begin{array}{l}\text { Resultado da análise de amostras de águas do } \\
\text { Córrego Água das Pedras apontaram, no ponto de } \\
\text { jusante a área do aterro, desenquadramento dos } \\
\text { padrões DBO e OD. }\end{array}$ \\
\hline Dezembro 2002 & Multa & $\begin{array}{l}\text { Lançamento "in natura" de chorume no solo, } \\
\text { devido ao entupimento de um dos drenos, } \\
\text { atingindo córrego das proximidades. Ocasionou } \\
\text { incômodos a vizinhança, impossibilitando a } \\
\text { dessedentação de animais, e a falta de oxigênio no } \\
\text { Córrego Água das Pedras prejudicando os peixes. }\end{array}$ \\
\hline Janeiro 2003 & - & Vazamento de chorume \\
\hline
\end{tabular}


Com relação ao chorume, em 1999, estava ocorrendo recalque do mesmo para o topo do aterro. Em janeiro de 2002, a disposição dos resíduos estava ocorrendo em área impermeabilizada com lona e sistema de drenagem de chorume, gases e sistema de captação de águas pluviais. Em maio de 2003, os líquidos percolados eram encaminhados para tanques de recebimento e recirculados na massa de resíduos através de bombeamento. Não havia vazamento de chorume na área do aterro.

Em 1999, o lixo hospitalar estava sendo encaminhado para incineração em Ribeirão Preto e em janeiro de 2002 estava sendo mantido em área separada, fechada, para ser encaminhado para destruição em Campinas (tratamento por microondas). Amostragens realizadas da água dos ribeirões em julho de 2001 e março de 2002 mostraram que os valores encontrados encontravam-se de acordo com o previsto na legislação vigente.

Uma licença para a ampliação do aterro foi negada pelo Departamento de Avaliação de Impacto Ambiental (DAIA) em janeiro de 2002, tendo em vista as condições inadequadas da unidade de disposição de resíduos e o elevado potencial de degradação ambiental.

Em março de 2002, o município alegava que a disposição dos resíduos sanitários, nas áreas denominadas emergenciais, era o melhor local para o desenvolvimento das atividades, visto que não havia como paralisar a coleta e disposição dos resíduos, até que um novo aterro sanitário fosse implantado, através de estudo de zoneamento ambiental, o qual encontra-se em processo de avaliação. Um plano de encerramento de duração de 20 meses para a área de disposição de resíduos no aterro sanitário foi entregue. Esse plano está atrelado a escolha de nova área e implantação de novo projeto de aterro sanitário, cujos estudos estão sendo desenvolvidos.

Em dezembro de 2002, o aterro sanitário estava recebendo em média 300 toneladas por dia de resíduos sólidos domésticos. Em 2003, providências começaram a ser tomadas para a seleção de uma nova área e implantação de um novo aterro sanitário em Piracicaba.

Contudo, tendo em vista todo impacto negativo causado pelo aterro sanitário, principalmente os problemas de contaminação e lançamento de chorume nos corpos 
d'água, devemos considerar que apesar da situação do aterro estar aparentemente controlada segundo inspeção da CETESB em determinadas datas, a situação continua sendo extremamente crítica. Danos irreversíveis ao ambiente podem ter sido causados e existe um risco de acidentes que ainda podem ocorrer mesmo depois da construção do novo aterro. O chorume continuará sendo gerado por mais um bom período, apesar da disposição de resíduos no local ser encerrada, e se não for bem controlado, monitorado, a manutenção não ser adequada, novos vazamentos poderão ocorrer e prejudicar ainda mais a qualidade da água utilizada para irrigação de hortaliças.

\section{Qualidade da água}

A ausência de mata ciliar e o uso inadequado do solo que caracterizam esta bacia, têm provocado a diminuição do volume de água, a perda da fertilidade do solo, aumento da ocorrência de enxurradas e inundações, deslizamento de encostas, redução das áreas úteis para agricultura e pecuária, assoreamento de nascentes e do leito dos ribeirões. Estes fatores, entre outros, comprometem diretamente a qualidade e a quantidade das águas e conseqüente perda da qualidade de vida dos moradores locais e dos consumidores de seus produtos (SEMA, 2003).

O saneamento básico da zona rural e de bairros adjacentes é precário. O esgoto urbano é lançado diretamente no ribeirão sem tratamento, contribuindo para a proliferação das populações de microorganismos patogênicos ao homem e aumentando o número de casos de doenças. A existência de um Aterro Sanitário Municipal ativo na bacia é outro importante fator poluidor e causador de mudanças sociais.

As águas do Território Nacional são classificadas segundo a qualidade requerida para seus usos preponderantes conforme a Resolução no 20/86 e n 357/05 do Conselho Nacional do Meio Ambiente (CONAMA). A Resolução no 357/05 também dispõe sobre as diretrizes ambientais para o enquadramento dos corpos de água superficiais, além de estabelecer condições e padrões para o lançamento de efluentes. Segundo esta, o enquadramento consiste no estabelecimento da meta ou objetivo de qualidade da água a ser alcançado ou mantido em um segmento de corpo de água, de acordo com os usos preponderantes pretendidos ao longo do tempo. Nas bacias hidrográficas em que a 
condição de qualidade esteja em desacordo com estes usos, metas intermediárias e final, de melhoria da qualidade da água para efetivação dos respectivos enquadramentos, devem ser estabelecidas, excetuados nos parâmetros que excedam aos limites devido às condições naturais.

Os corpos d’água da bacia dos Marins estão enquadrados como classe 2, de acordo com o Decreto Estadual $n^{0} 10.755$ de 22/11/77 que obedeceu os padrões fixados pelo Decreto Estadual $n^{0} 8.468$ de 8/9/76. Cabe ressaltar que o enquadramento dos corpos de água não está baseado necessariamente no seu estado atual, mas nos níveis de qualidade que devem possuir para atender às necessidades da comunidade. Conforme os padrões estabelecidos pelas Resoluções CONAMA 20/86 e 357/05, na classificação das águas doces variando de 1 a 4, a classe 1 representa a água de melhor qualidade necessária para usos mais exigentes com relação a diversos parâmetros e a classe 4 de pior qualidade. Para a irrigação de hortaliças que são consumidas cruas e de frutas que se desenvolvam rentes ao solo e que sejam ingeridas cruas sem remoção de película, são necessárias as águas de classe 1, e para as demais hortaliças e plantas frutíferas as águas de classe 2.

Um corpo d’água poluído por lançamentos de matéria orgânica biodegradável sofre um processo natural de recuperação denominado autodepuração. Este realiza-se através de processos físicos como diluição e sedimentação, químicos (oxidação) e biológicos. Portanto, a decomposição da matéria orgânica corresponde a um processo integrante deste mecanismo de autodepuração (Braga et al., 2002). A vazão de diluição, o potencial poluidor, a concentração de oxigênio dissolvido no curso d’água, dentre outras características influenciam o mencionado processo. Assim, a distância do trecho do ribeirão entre os pontos de coleta (Tabela 18) fornece subsídios para avaliar a possibilidade de alterações na qualidade da água ao longo do ribeirão devido este processo de recuperação, lançamento de efluentes, assoreamento, dentre outros fatores que podem ser responsáveis por variações de diferentes grandezas ao longo do ribeirão. 
Tabela 18. Comprimento do ribeirão dos Marins entre os pontos de amostragem

\begin{tabular}{ccc}
\hline Comprimento do ribeirão & \multicolumn{2}{c}{ Distância } \\
entre os pontos de coleta & $\mathbf{m}$ & $\mathbf{k m}$ \\
\hline nascentes - 1 & 6589,1 & 6,6 \\
$1-2$ & 2239,5 & 2,2 \\
$2-3$ & 4566,0 & 4,6 \\
$3-4$ & 1746,5 & 1,7 \\
$4-5$ & 3604,3 & 3,6 \\
$5-6$ & 1289,7 & 1,3 \\
$6-7$ & 1850,5 & 1,9 \\
7 - foz & 371,0 & 0,4 \\
Total & 22256,5 & 22,3 \\
\hline
\end{tabular}

A condutividade indica a quantidade de sais existentes na coluna d’água e pode representar uma medida indireta da concentração de poluentes. Este parâmetro fornece informação das modificações na composição de uma água, especialmente referente a sua concentração mineral. Porém, não fornece indicação das quantidades relativas dos vários componentes. Considerando os valores apresentados pela CETESB (2001) para alguns corpos d’água no estado de São Paulo em regiões com características semelhantes a da bacia dos Marins, as quais possuem uma maior influência antrópica, os valores medianos da condutividade encontrados no ribeirão dos Marins (Figura 15) sugerem que esta apresenta um nível médio a elevado de degradação. Podemos observar que os valores aumentam ao longo do ribeirão, principalmente no período da seca no qual estes são maiores que na cheia em todos os pontos de amostragem. Na proximidade do ponto 4 observa-se valores mais elevados da condutividade provavelmente devido a maior interferência antrópica a partir deste, maior proximidade da área urbana e lançamento de efluentes. Contudo, as atividades agrícolas, o enriquecimento das águas em íons pela drenagem dos solos também interferem nos valores da condutividade, apesar de predominar a influência do lançamento de efluentes. 


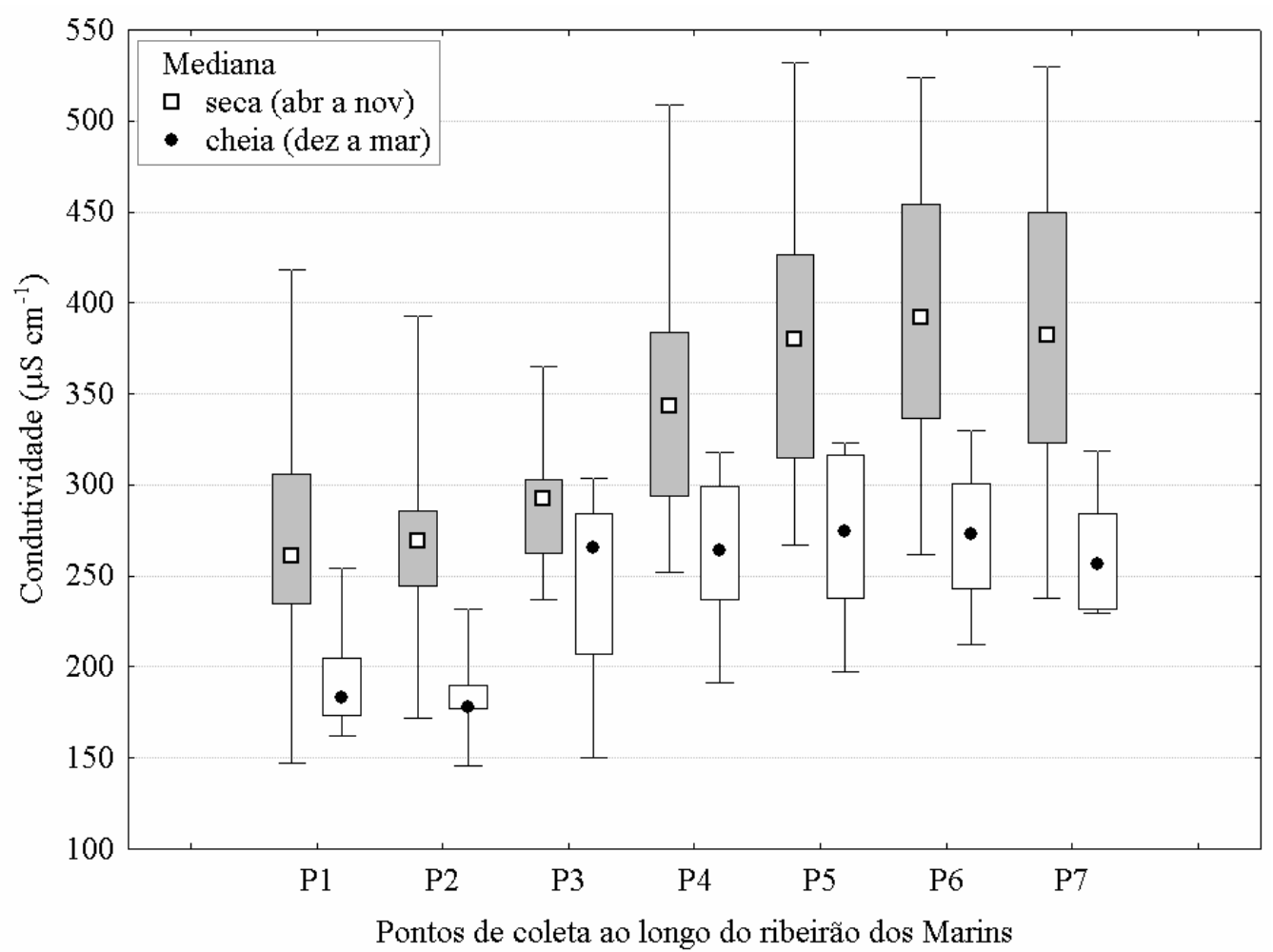

Figura 15 - Valores das medianas, quartis e extremos da condutividade nos pontos de coleta ao longo do ribeirão dos Marins nas estações seca e cheia

A concentração de sólidos suspensos em um corpo d'água pode variar com a descarga e com lançamento de esgotos doméstico ou industrial. O tipo de ocupação territorial e a precipitação podem intensificar processos erosivos, os quais também podem ser responsáveis pelo aumento de sólidos em suspensão na água. As medianas das concentrações de Sólidos Suspensos Totais (SST) para a seca e cheia podem ser visualizadas na Figura 16. A variação na concentração dos SST ao longo do ribeirão pode ter sido afetada pela entrada dos afluentes, aumentando a vazão, e pela ocorrência de chuvas que aumentam o carreamento de partículas para água. O lançamento de efluentes no ribeirão também pode ter contribuído para o aumento da concentração de sólidos na água. Nota-se valores mais elevados de sólidos suspensos na cheia, provavelmente devido a maior vazão e chuva no período, o que aumenta o carreamento de partículas. 


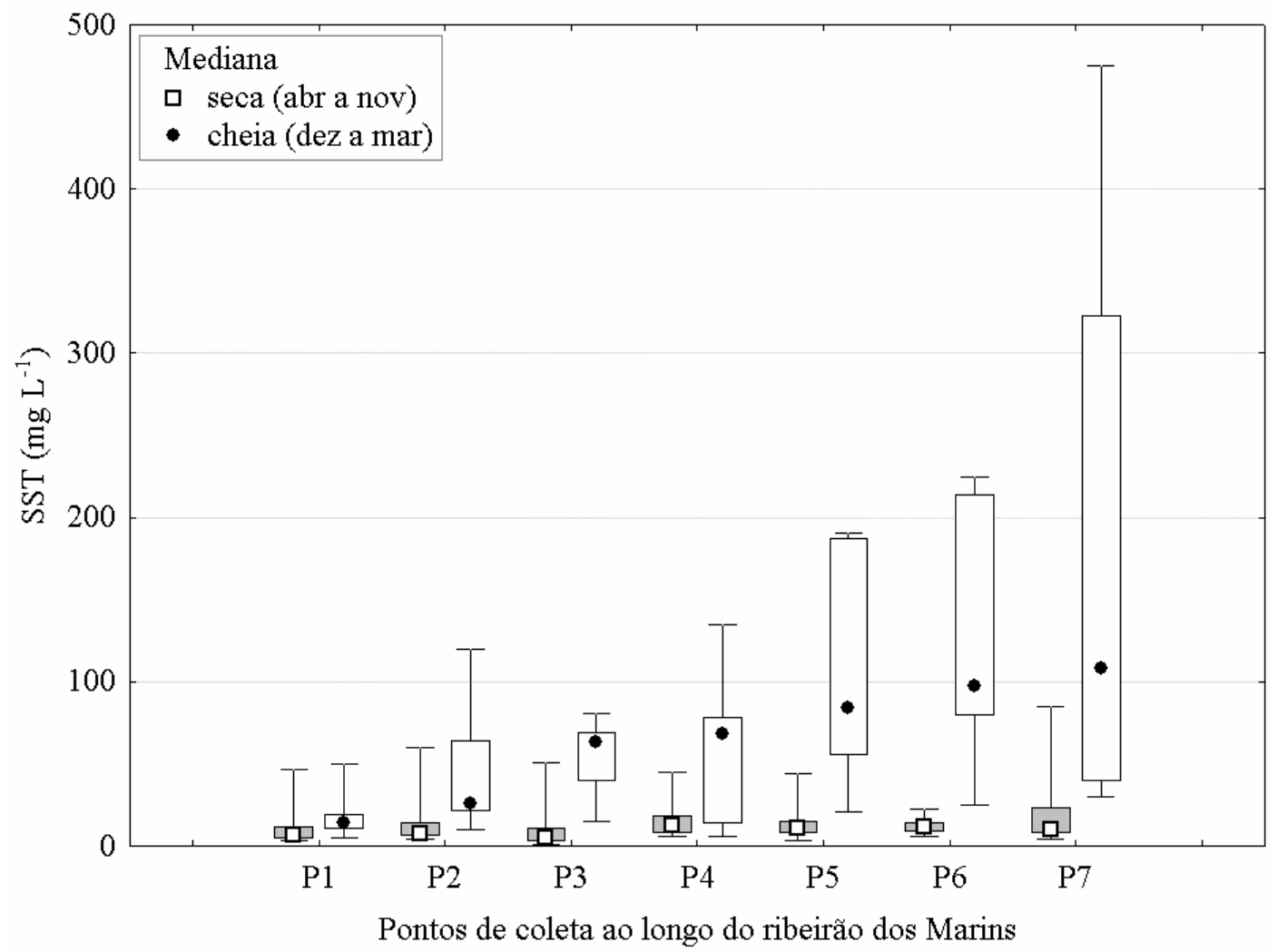

Figura 16 - Medianas, quartis e valores máximos e mínimos das concentrações de sólidos suspensos totais no ribeirão dos Marins nas estações seca e cheia

O Oxigênio Dissolvido (OD) é extremamente importante para os organismos aeróbicos. Durante a estabilização da matéria orgânica, as bactérias fazem uso do oxigênio nos seus processos respiratórios, podendo causar uma redução da sua concentração no meio. Dependendo da magnitude deste fenômeno podem vir a morrer diversos seres aquáticos (Von Sperling, 1996). Com a medição do teor de oxigênio dissolvido, os efeitos de resíduos oxidáveis sobre águas receptoras, durante a oxidação bioquímica, podem ser avaliados (CETESB, 2001).

O esgoto lançado nos cursos d’água sem tratamento prévio compromete o processo natural de recuperação dos rios. Em muitos casos, a vazão dos rios não é suficiente para promover a depuração de toda matéria orgânica e muitos processos vitais são afetados com o aumento da demanda de oxigênio. O parâmetro OD indica um maior aporte de matéria orgânica, o qual pode ser proveniente do esgoto ou não. Embora no estado de São Paulo, principalmente em regiões com lançamento de efluentes e elevada 
interferência antrópica, o OD seja utilizado como um indicativo da poluição, baixos teores deste não indica necessariamente que o ambiente está sendo degradado. Valores baixos de oxigênio também podem ser encontrados em ecossistemas preservados, como ocorre em rios da bacia Amazônica devido a processos inerentes às características da bacia, onde valores menores que $5 \mathrm{mg} \mathrm{L}^{-1}$ podem ser encontrados. Tal fato é explicado por Devol et al. (1995), o qual concluiu ao realizar um estudo no rio Amazonas, que a concentração do oxigênio dissolvido apresenta um ciclo sazonal que resulta principalmente das variações devido à diferença de profundidade do rio.

As porcentagens de saturação de oxigênio encontradas na seca e cheia nos sete pontos de coleta no ribeirão dos Marins pode ser visualizada na Figura 17. Nota-se que na bacia dos Marins, as quedas nos valores de oxigênio dissolvido são resultantes de um maior aporte de matéria orgânica, que é determinado na região principalmente pelo volume de efluentes lançados no ribeirão.

As maiores porcentagens de saturação de OD no ribeirão dos Marins ocorrem nos pontos de coleta do início até o ponto 4 quando os valores sofrem uma redução principalmente na seca (Figura 17). Este fato ocorre provavelmente devido a menor vazão para diluição da alta carga orgânica advinda dos efluentes que são lançados no corpo d’água, pois ocorre em maior quantidade despejo de esgoto de alguns bairros no ribeirão próximo ao ponto 4 e um pouco antes do ponto 6 (Figura 18). No ponto 1 o menor percentual de OD encontrado que nos pontos 2 e 3 na cheia pode ocorrer devido ao maior arraste de matéria orgânica quando chove, o que pode estar ocorrendo em maior quantidade no primeiro setor da bacia devido ao uso e cobertura do solo do local e a menor cobertura florestal principalmente nas áreas de preservação permanente. Assim, para a decomposição de uma maior quantidade de matéria orgânica, ocorre um decréscimo nos percentuais de oxigênio dissolvido na água, o qual é utilizado devido a respiração dos decompositores aeróbios. 


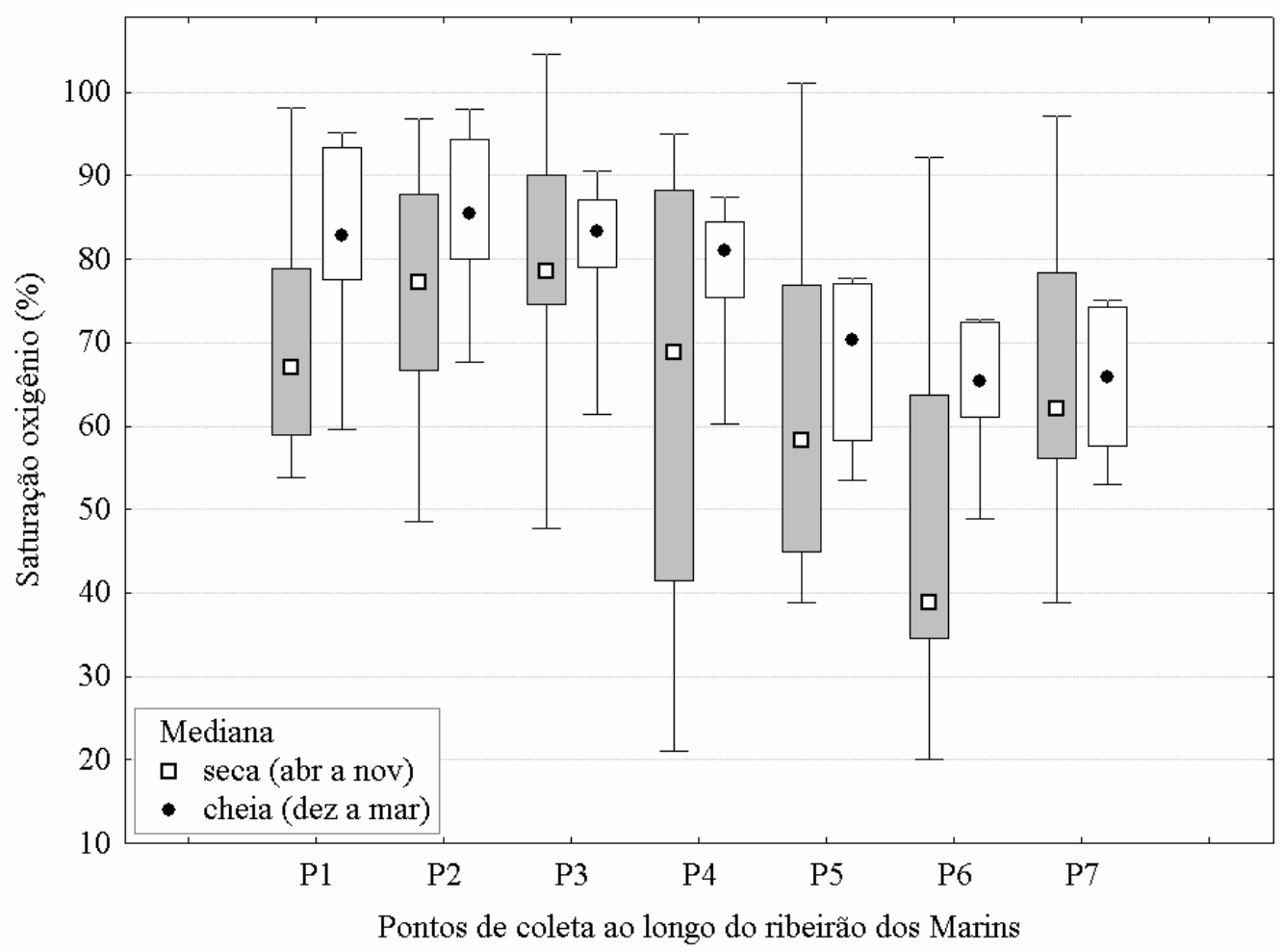

Figura 17 - Distribuição da saturação de oxigênio dissolvido ao longo do ribeirão dos Marins nas estações seca e chuvosa

Na Figura 18 podemos observar a localização dos pontos de amostragem da água em relação a alguns pontos de lançamento de esgoto (Ruffolo, 2003), a rede de esgoto e principais indústrias e empreendimentos. Como foi mencionado anteriormente, ocorre lançamento de esgoto doméstico diretamente na água do ribeirão antes do P4 e entre o P5 e P6, devido à presença de bairros urbanos. Este fato ocasiona preocupação, pois é nesta região da bacia que a água é utilizada para a irrigação de grande quantidade de hortas produtoras principalmente de folhas, como alface, couve etc (SEMA, 2003).

De acordo com a Resolução CONAMA 20/1986 e 357/2005, a concentração de OD na água referente às classes 1, 2, 3 e 4 não deve ser inferior a 6, 5, 4 e 2 mg L ${ }^{-1}$, respectivamente. Embora, esses valores possam não significar que a água está poluída, no caso de valores baixos de OD não ser uma característica natural da região, devemos considerar os valores estabelecidos pela legislação para avaliar a situação dos corpos d’água na bacia. Estes, conforme mencionado anteriormente, na bacia dos Marins estão 
enquadrados como classe 2. Cabe ressaltar que, para esta classe o OD não deveria ser inferior a $5 \mathrm{mg} \mathrm{L}^{-1} \mathrm{O}_{2}$, o que pode ser verificado nos valores medianos encontrados de OD para o período seco, sendo 4,8 e 3,4 $\mathrm{mg} \mathrm{L}^{-1}$ nos pontos 5 e 6 , respectivamente.

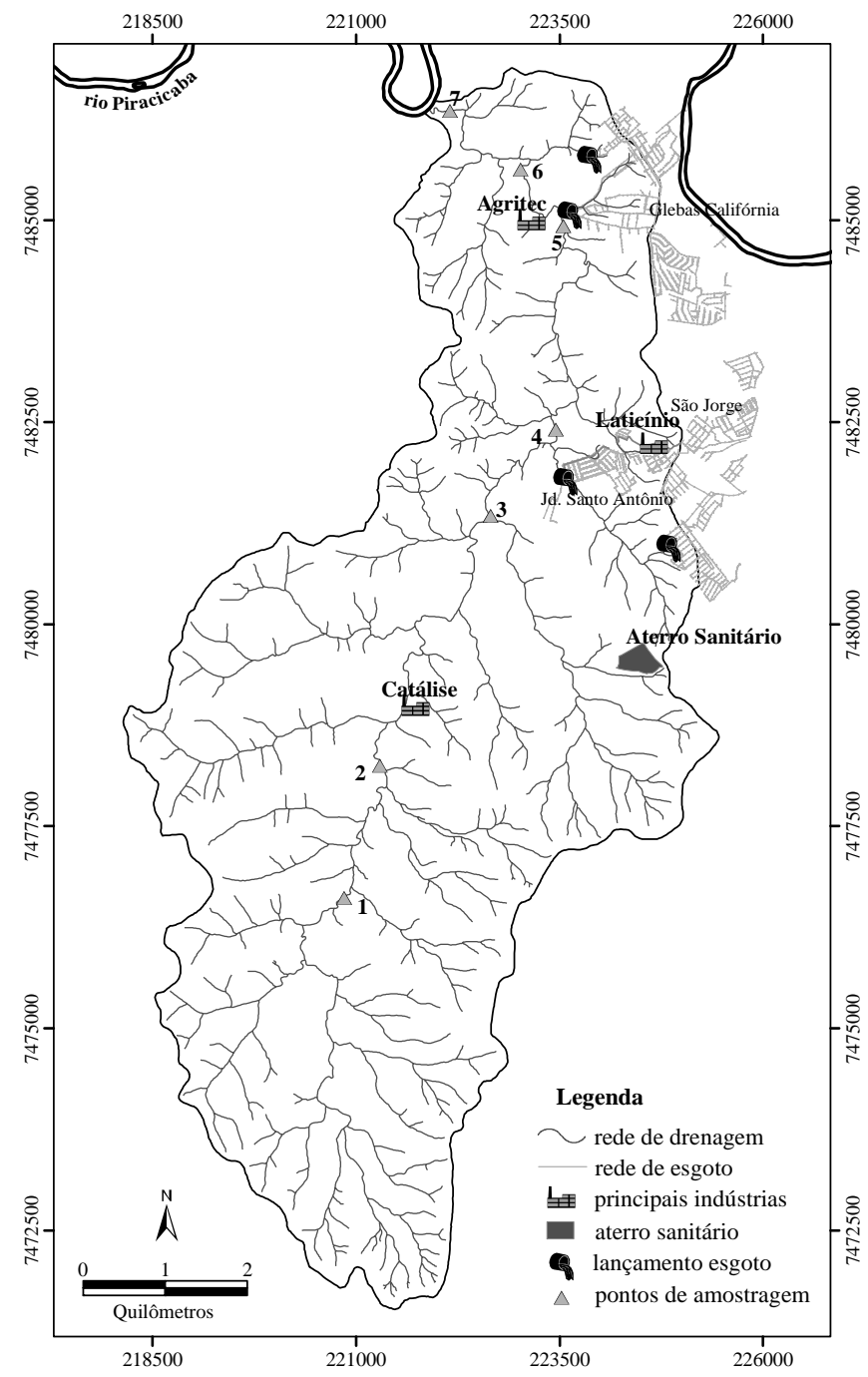

Figura 18 - Localização dos pontos de coleta de água, principais indústrias e empreendimentos e pontos de lançamento de esgoto nos cursos d'água da bacia dos Marins

Com base nos dados das análises não foi possível observar nenhuma interferência na qualidade da água devido às principais indústrias identificadas (Figura 18). Estas apresentam apenas os riscos de contaminação mencionados anteriormente, sendo alguns deles referentes aos solos e no caso de acidentes. Elas são monitoradas pela 
CETESB e não devem gerar efluentes líquidos que interfiram na qualidade da água do ribeirão.

Os coliformes fecais são um grupo de bactérias indicadoras de organismos originários do trato intestinal humano e de outros animais de sangue quente. O uso destes para indicar a poluição sanitária é extremamente significativo, pois é um parâmetro indicador da possibilidade da existência de microorganismos patogênicos, responsáveis pela transmissão de doenças de veiculação hídrica, como febre tifóide, febre paratifóide, desinteria bacilar e cólera (Von Sperling, 1996; CETESB, 2001).

Os resultados das determinações de coliformes fecais na água do ribeirão dos Marins podem ser visualizados na Figura 19. A menor mediana destes valores foi obtida no ponto 1 na seca (170 NMP 100 $\mathrm{mL}^{-1}$ ) e a maior na cheia no ponto 7 (50.000 NMP $100 \mathrm{~mL}^{-1}$ ). Os valores determinados para o ponto 4 na seca também foram extremamente elevados, sendo estes provavelmente resposta do despejo de esgoto urbano próximo ao ponto 4. O mesmo foi verificado no ponto 6 na cheia. Cabe ressaltar o aumento nos valores encontrados, principalmente a partir do ponto 4, como resposta do lançamento de efluentes domésticos.

Os valores medianos encontrados de coliformes fecais em todos os pontos com exceção do ponto 4 foram maiores na cheia. No ponto 4 uma maior quantidade de esgoto é lançado, o que também pode ser observado pelos valores do projeto das estações elevatórias do SEMAE, através destes podemos observar uma vazão estimada de esgoto gerado um pouco maior na região das elevatórias do Santo Antônio, as quais estão situadas próximas do ponto 4. Uma outra possível justificativa pode ser a característica do uso e cobertura do solo do entorno, principalmente nas áreas de preservação permanente, uma vez que o uso de esterco e a presença de alguns animais no entorno também pode interferir nos valores de coliformes fecais encontrados, sendo o escoamento superficial um componente importante.

Contudo, as maiores variações observadas nos resultados estão associadas ao lançamento de esgoto sem prévio tratamento no ribeirão e, ainda, provavelmente ao uso de esterco de origem animal como fertilizantes nos canteiros das hortas. Uma outra possível fonte de poluição pode ser a presença de fossas inadequadas, construídas em 
chácaras sobre solos de textura média a arenosa, podendo contaminar o lençol freático e o ribeirão.

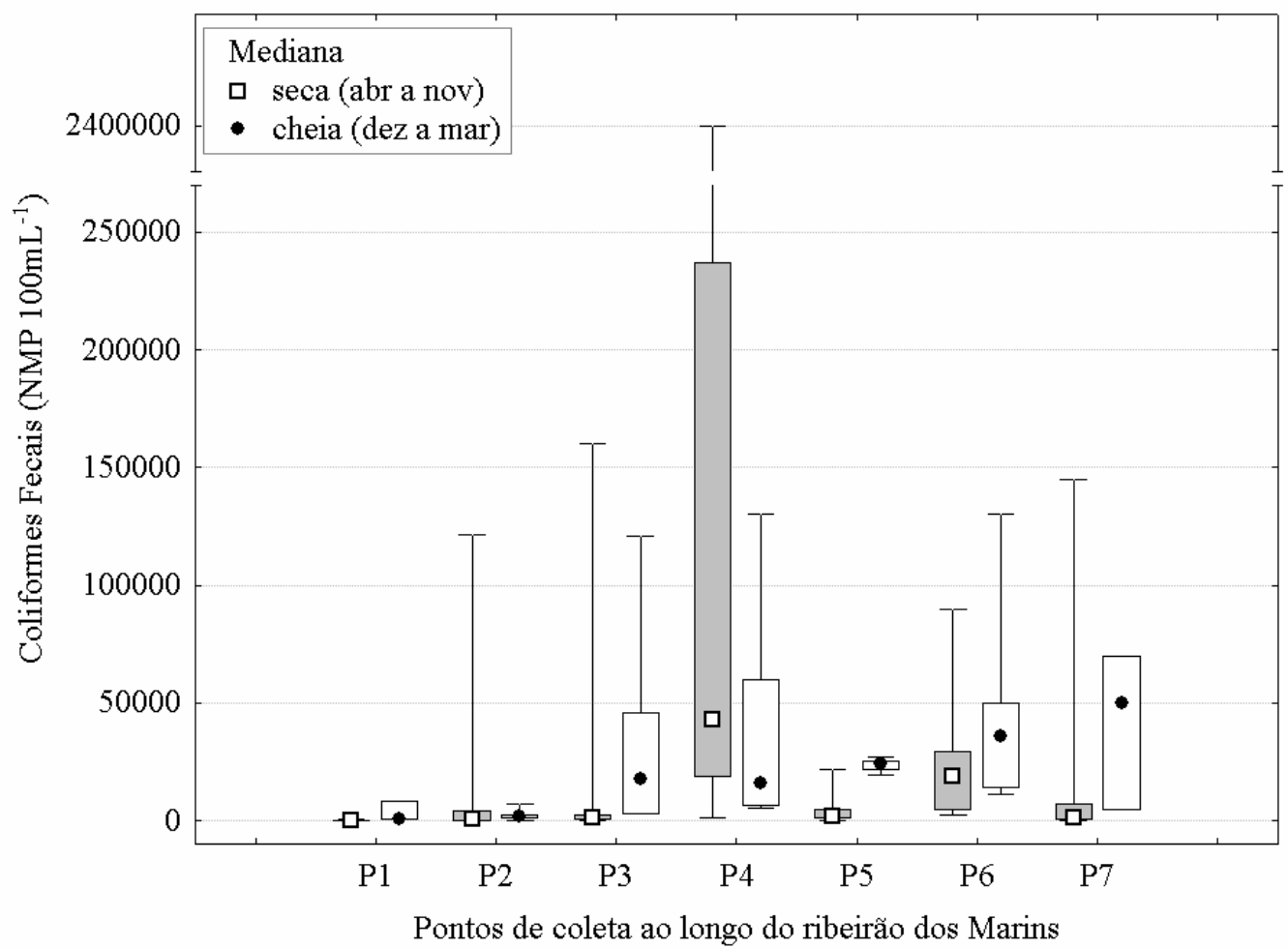

Figura 19 - Medianas, quartis e valores máximos e mínimos de coliformes fecais nos pontos de coleta ao longo do ribeirão dos Marins nas estações seca e cheia

De acordo com os limites estabelecidos pela Resolução CONAMA 20/1986 e 357/2005, apenas a mediana referente aos coliformes fecais encontrada na seca no ponto 1 atende ao padrão estabelecido para classe 1 . As medianas referentes aos pontos 2, 3 e 7 na seca e ao ponto 1 na cheia correspondem a classe 2 . A água nos pontos 5 na seca e 2 na cheia atendem aos limites estabelecidos para a classe 3, não podendo ser utilizada para a dessedentação de animais criados confinados. Nos demais pontos de coleta e período, no ponto 4 e 6 na seca os quais possuem maior influencia do lançamento de esgoto e a partir do ponto 3 na cheia, os valores encontrados correspondem a classe 4.

Os valores médios de coliformes fecais determinados para os locais de amostragens demonstraram que a poluição foi significativa. De modo geral, a poluição da bacia é crescente desde as nascentes até a foz. Porém, esta poluição é caracterizada 
por acréscimos nos locais de maior concentração humana, junto a bairros residenciais, de lazer ou de cultivo de hortaliças (SEMA, 2003).

De acordo com as observações de campo do projeto (SEMA, 2003) próximo ao ponto 4 (Rodovia SP-147 - Jardim São Jorge), a presença de um local de lançamento de esgoto foi constatado. Com base na resolução CONAMA n 20 de 18/06/1986 e 357 de 17/03/2005, apenas águas que atendam aos limites da classe 1 podem ser destinadas à irrigação de hortaliças, que são consumidas cruas e de frutas que se desenvolvam rentes ao solo e que sejam ingeridas cruas sem remoção de película. Como para a irrigação das demais hortaliças e plantas frutíferas, as águas devem ser da classe 2, com base nas medianas dos valores encontrados de coliformes fecais, apenas o trecho do ponto 1 no ribeirão dos Marins tem água de boa qualidade para a irrigação de hortaliças em ambos os períodos. Contudo, a maioria das hortas estão localizadas no trecho final da bacia, sendo que em todos os demais pontos na cheia a água não poderia ser utilizada para a irrigação das hortaliças.

O artigo $1^{\circ}$ da Portaria do Centro de Vigilância Sanitária CVS- 21, de 19.12.91, estabelece que a água usada para a irrigação de plantações de hortaliças e frutas rasteiras não pode conter uma concentração superior a 1000 coliformes fecais em $100 \mathrm{~mL}$ de amostra, assim, a água do ribeirão dos Marins nos pontos amostrados não pode ser utilizada para a irrigação de hortaliças em ambos os períodos, com exceção do ponto 1.

\section{Uso e cobertura do solo}

Na Figura 20 podemos observar os mosaicos de 1962, 1995 e 2000, formados com as fotografias aéreas georreferenciadas da bacia do ribeirão dos Marins. Um resultado satisfatório foi obtido para o objetivo deste trabalho e as distorções minimizadas. A sobreposição dos mosaicos com a rede de drenagem está coerente (Figura 20). Assim, notamos que uma boa junção entre as fotografias foi obtida, possibilitando a elaboração do mapa de vegetação com base nos mosaicos e a determinação das áreas de preservação permanente a partir da rede de drenagem. 

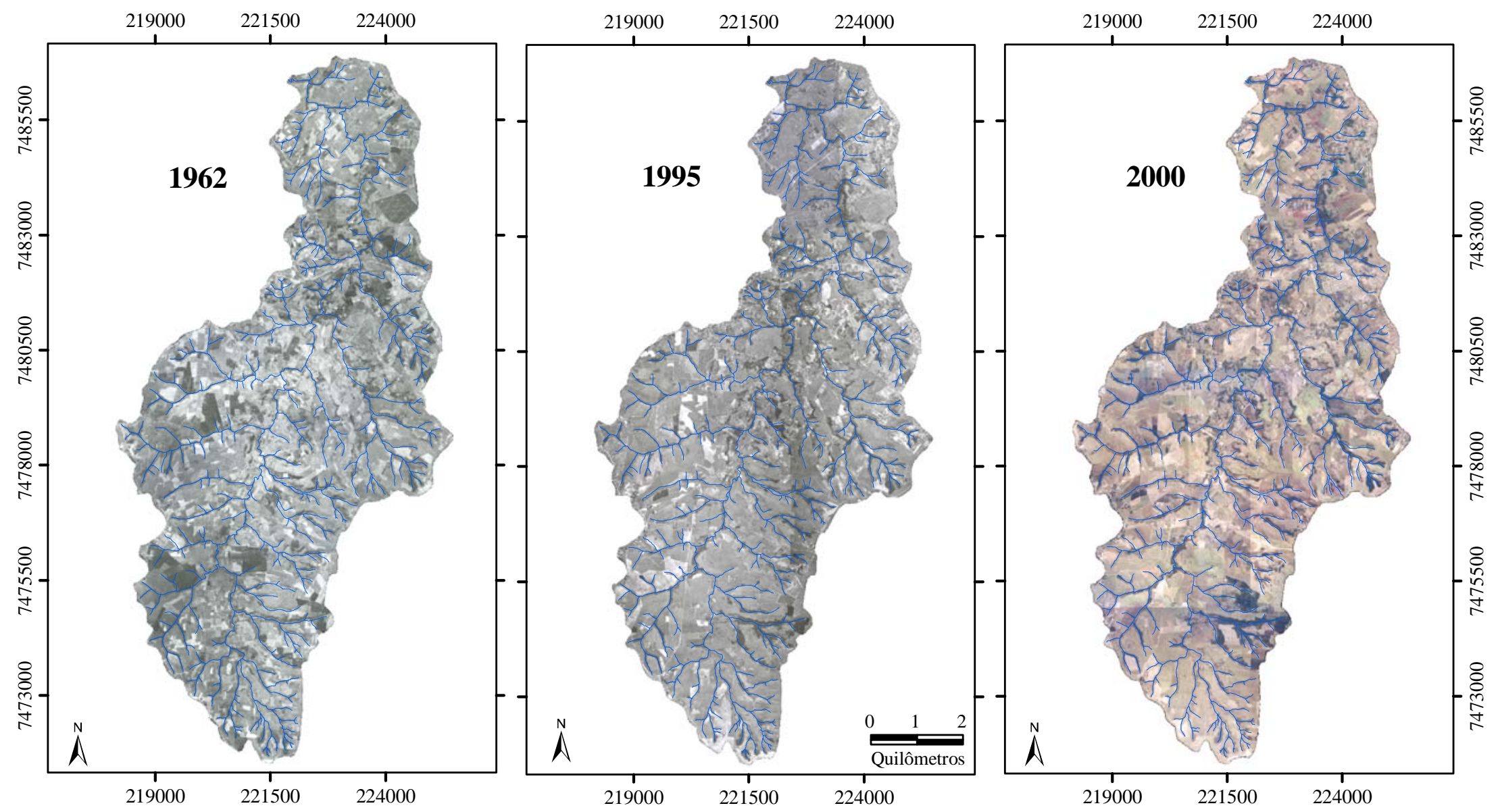

Figura 20 - Sobreposição dos mosaicos de fotografias aéreas de 1962, 1995 e 2000 com a rede de drenagem da bacia do ribeirão dos Marins 
Os mosaicos obtidos, além de permitirem a elaboração dos mapas de vegetação, possibilitam uma visão global da bacia e a observação de alterações que estão ocorrendo na paisagem como um todo. No formato digital e utilizando um programa adequado, podem auxiliar no desenvolvimento de diversos mapas temáticos e facilitam a observação de vários detalhes. O mosaico de 2000 foi extremamente útil quando utilizado para a direcionar levantamentos de campo e localizar pontos.

Em termos de uso e cobertura do solo, algumas modificações que ocorreram na paisagem da área de estudo podem ser observadas nas fotografias aéreas dos diferentes anos apresentadas na Figura 21. Esta mostra alterações na paisagem com destaque para a expansão da área urbana e para a formação de hortas.
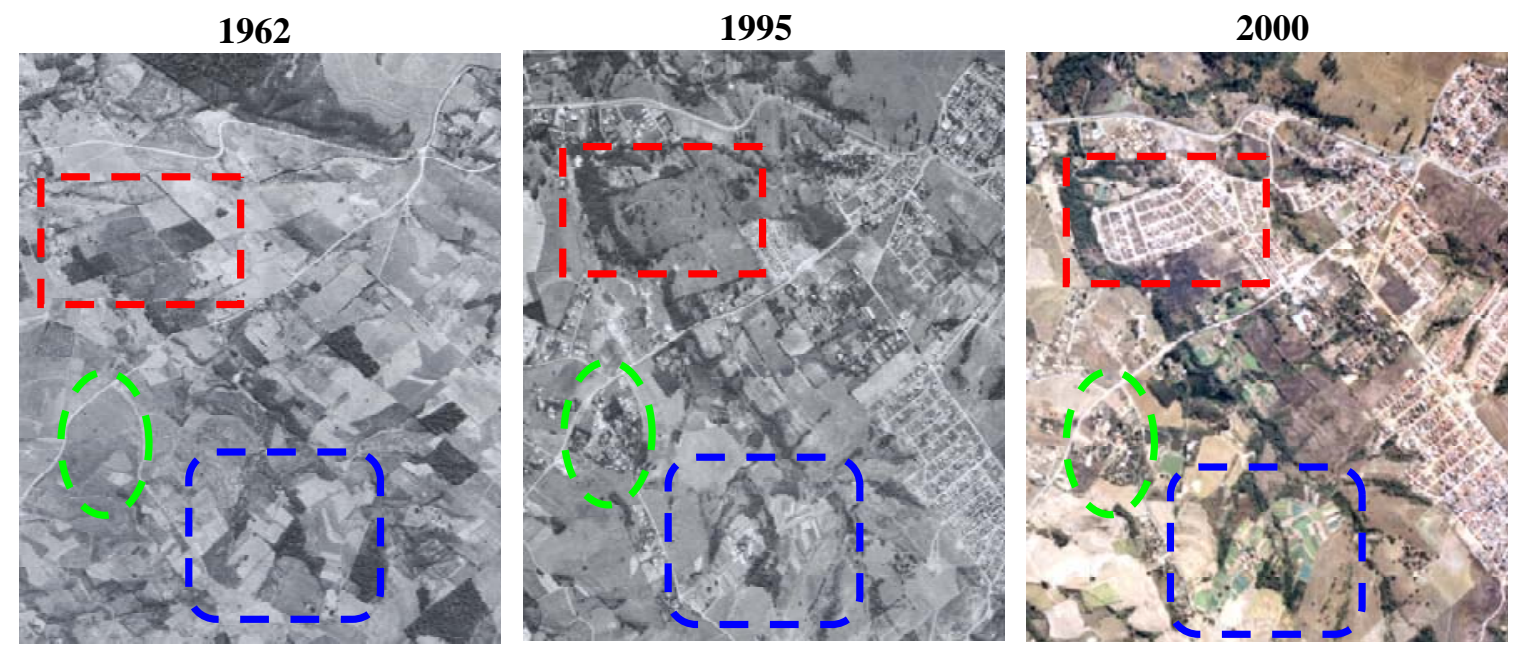

Figura 21 - Fotografias aéreas de 1962, 1995 e 2000 mostrando alterações na paisagem da bacia do ribeirão dos Marins

Em 2000, de acordo com o mapa de uso e cobertura do solo elaborado a partir das fotografias aéreas, na bacia predominam áreas com pasto (38 \%) e cana-de-açúcar (34,6 \%). A classe fragmento florestal ocupava 11,4 \% da área da bacia, a floresta plantada 3,3 \% e a urbanização 6,7 \%. Cabe ressaltar que foi observada na área de estudo a presença de muitas represas, açudes, barreiros e lagos, sendo a existência de muitos deles verificada em trabalho de campo. No mapa de uso e cobertura do solo de 
2000 puderam ser identificados 146 polígonos referentes a essas superfícies de água, estando estes presentes no curso d'água ou não.

A pastagem e a cultura da cana-de-açúcar predominam nos três setores que formam a bacia do ribeirão dos Marins (Figura 22). O percentual destas classes em cada setor diminui do setor inicial para o final. O oposto ocorre com os fragmentos florestais, os quais aumentam das cabeceiras até a foz, ocupando 8,3 \% no setor inicial, 12,0 \% no central e 15,5 \% no final. Na Figura 22 observa-se que, além dos fragmentos florestais, cultura perene, horticultura, cultura anual e urbanização também aumentam em percentual rio abaixo. A floresta plantada apresenta o seu maior percentual no setor inicial e as represas ou reservatórios no setor central.

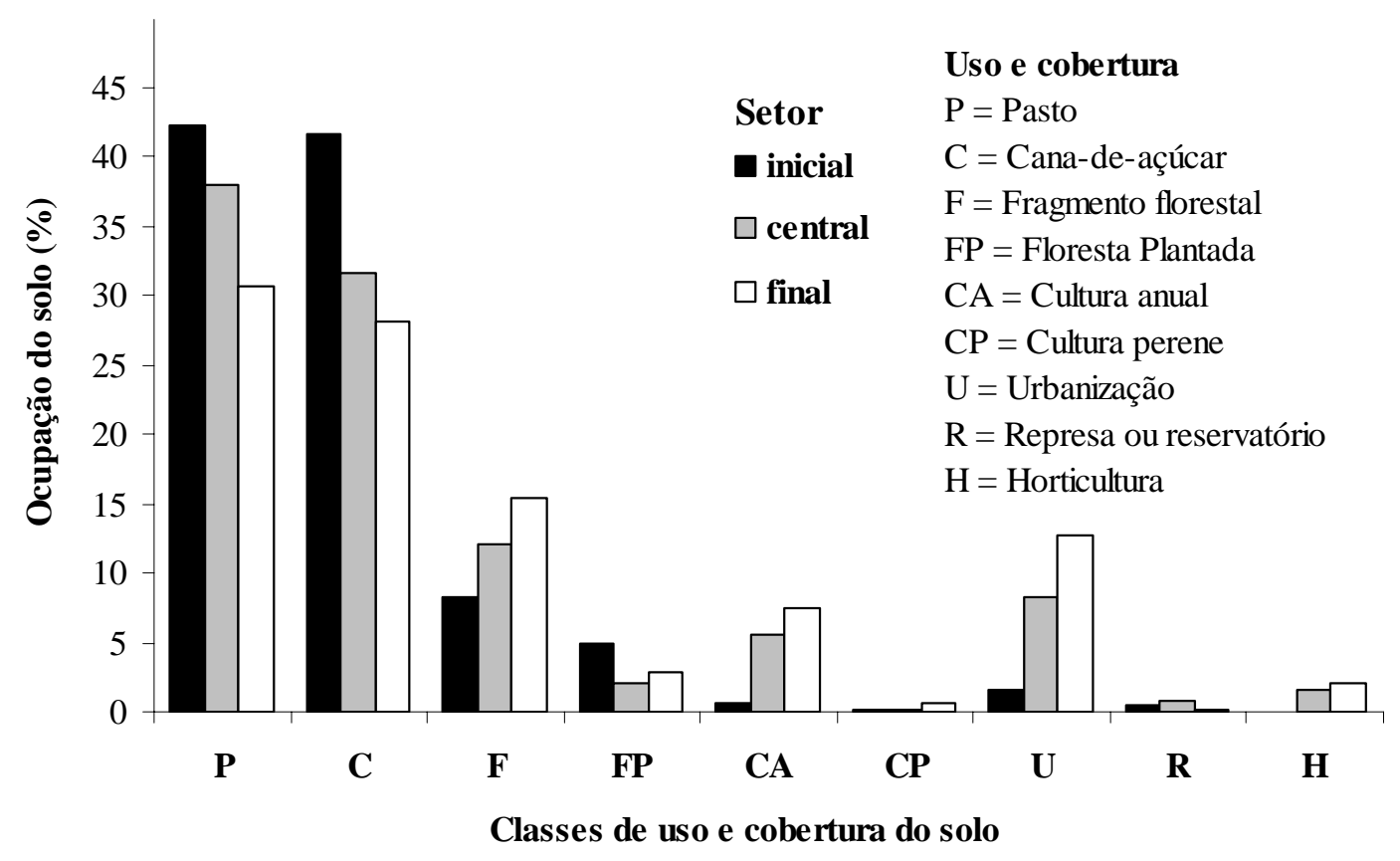

Figura 22 - Distribuição do uso e cobertura do solo nos setores inicial, central e final da bacia do ribeirão dos Marins

Na Figura 23 observa-se a distribuição das classes de vegetação nos setores que compõem a bacia. Nota-se que a floresta nativa é a classe de vegetação predominante nos três setores e que o percentual de áreas em regeneração aumentam nos setores conforme estes se aproximam da foz do ribeirão dos Marins. No setor inicial, a floresta 
plantada predomina em relação à regeneração. Nos demais setores o oposto ocorre. O maior percentual de floresta nativa em relação às outras classes de vegetação ocorre nos setores central e final. O percentual desta classe foi menor nas cabeceiras, onde representavam quase 50 \% da vegetação presente neste setor inicial. De modo geral, observa-se que o percentual de áreas em regeneração e floresta nativa são maiores no final da bacia. Além destas áreas, as cabeceiras da bacia são regiões que precisam ser preservadas, as quais acabam ficando sem cobertura vegetal, degradadas e expostas à ação erosiva.

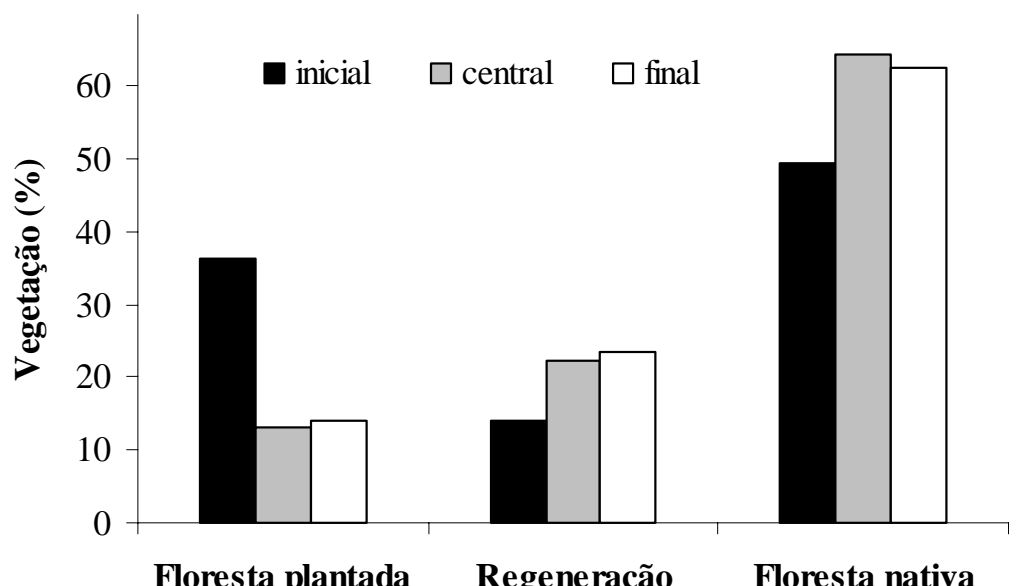

Classes de vegetação

Figura 23 - Distribuição das classes de vegetação nos setores inicial, central e final da bacia do ribeirão dos Marins

\section{Área de Preservação Permanente}

De acordo com as especificações do Código Florestal, constatamos que aproximadamente 19 \% da área da bacia dos Marins são áreas consideradas de preservação permanente ao longo dos cursos d'água (Figura 24). 


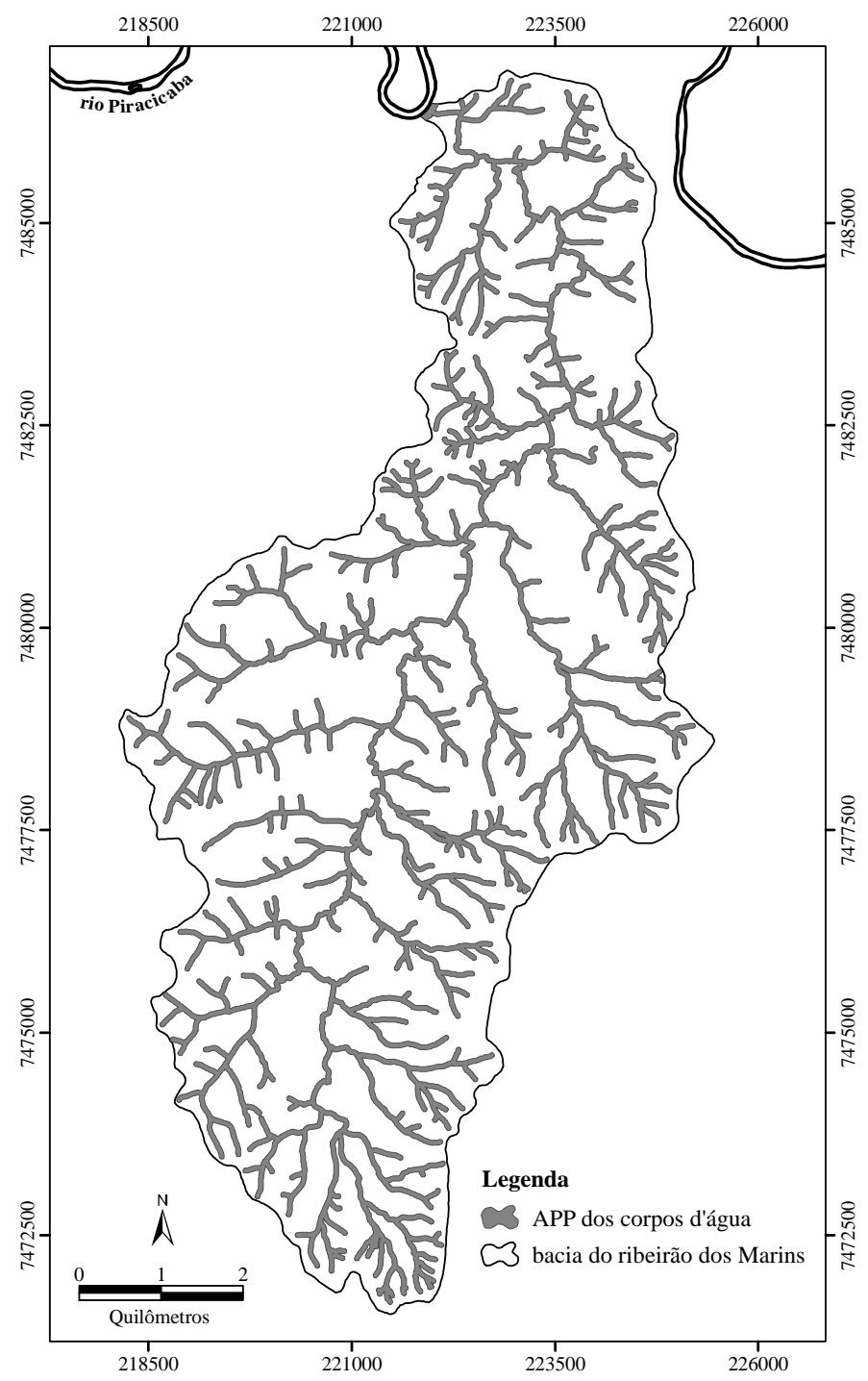

Figura 24 - Localização das Áreas de Preservação Permanente na bacia dos Marins

\section{Erosão}

Como pode ser observado na Tabela 19, os valores mensais médios do índice de erosividade da chuva confirmam a maior concentração do potencial erosivo de outubro a março, na estação chuvosa, período no qual a erosividade corresponde a aproximadamente 89 \% do total anual. O índice médio mensal de erosividade (EI) de janeiro e julho correspondem ao maior e menor valores encontrados ao longo do ano, respectivamente. 
Tabela 19. Erosividade (EI) e precipitação média ao longo do ano

\begin{tabular}{lrc}
\hline \multicolumn{1}{c}{ Mês } & $\begin{array}{r}\text { Precipitação média mensal } \\
(\mathbf{m m})\end{array}$ & $\boldsymbol{E I}$ \\
& 224 & 1507 \\
\hline Janeiro & 183 & 1073 \\
Fevereiro & 144 & 722 \\
Março & 63 & 181 \\
Abril & 54 & 136 \\
Maio & 43 & 94 \\
Junho & 27 & 43 \\
Julho & 30 & 52 \\
Agosto & 63 & 178 \\
Setembro & 110 & 458 \\
Outubro & 132 & 618 \\
Novembro & 200 & 1248 \\
Dezembro & 1.272 & 6309 \\
Total & & \\
\hline
\end{tabular}

Em pequenas áreas distribuídas ao longo da bacia dos Marins o valor do fator topográfico (LS) foi muito elevado, provavelmente devido a um erro desprezível (0,06 \% da área da bacia) característico da metodologia utilizada para o cálculo deste parâmetro. No entanto, isso não ocorre na maior parte da bacia, uma vez que em aproximadamente 98 \% da área da mesma o fator LS é menor que 10 (Figura 25).

Fujihara (2002) também encontrou valores elevados ao utilizar algoritmos computacionais e considerou a variação do LS aceitável, uma vez que a distribuição dos valores de LS por área relativa da microbacia indicou um comportamento semelhante para duas metodologias utilizadas. Uma está baseada na divisão da microbacia em rampas conforme descrito por Rocha et al. (1997) e a outra executada através do programa “USLE-2D”, o qual é composto por vários algoritmos computacionais de cálculo automatizado (Desmet \& Govers,1996). 


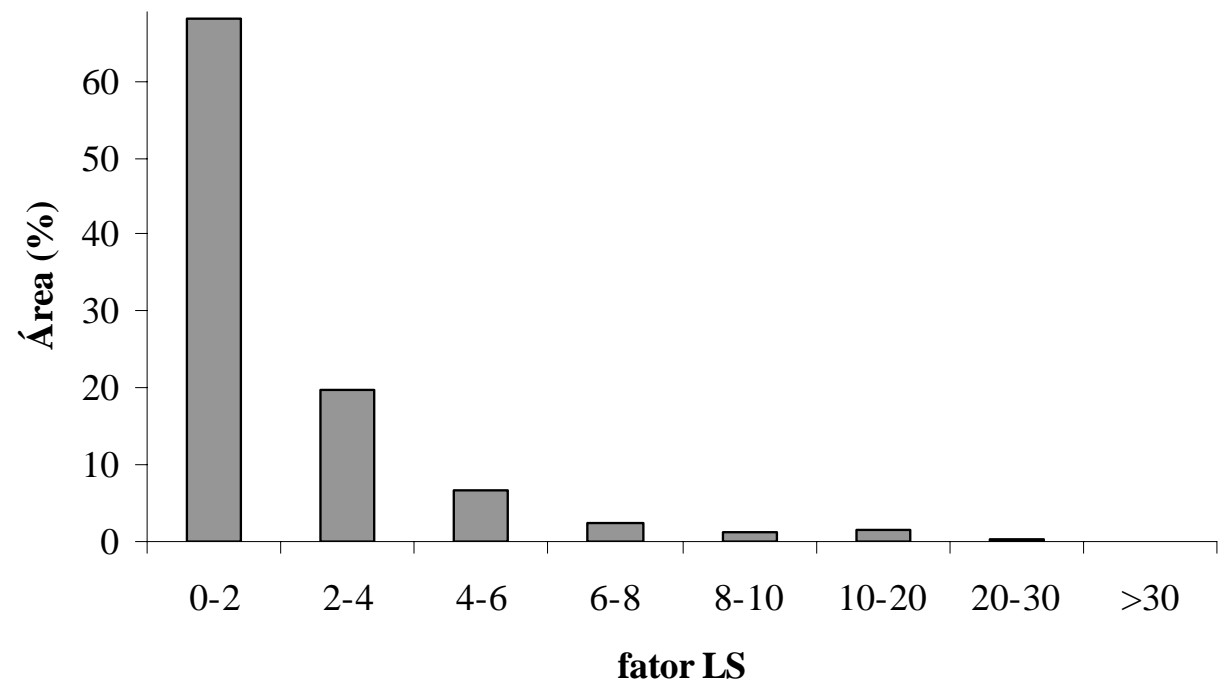

Figura 25 - Distribuição das classes do fator topográfico (LS) na bacia do ribeirão dos Marins

Diante dos aspectos apresentados, para a aplicação da EUPS na área de estudo, as áreas com valores do fator LS maiores que 30 foram desconsideradas.

Os valores do Potencial Natural de Erosão (PNE) calculado, que corresponde à perda de solo sem considerar o fator uso-manejo do solo e a adoção de prática conservacionista, foram agrupados em três classes (Figura 26). A variação do PNE foi proporcional ao fator LS e, conseqüentemente, também apresentou um conjunto insignificante de valores elevados. No entanto, como Fujihara (2002) também observou para o fator LS, a distribuição dos valores do PNE apresenta comportamento semelhante. Observa-se que o PNE na bacia dos Marins deve-se principalmente ao fator LS, nota-se que os locais com maior potencial natural de erosão correspondem às áreas com maior declividade.

Na Tabela 20 observa-se o percentual das áreas dos três setores que formam a bacia, das cabeceiras ao trecho final da mesma, em cada classe de risco de erosão em 2000. A situação mais crítica é encontrada no setor inicial, no qual os percentuais de áreas de risco de erosão alto e muito alto são maiores que nos demais setores. Os percentuais das áreas correspondentes às classes de risco baixo aumentam ao longo da 
bacia do setor inicial ao final, enquanto que os das demais classes, as quais são mais críticas, diminuem das cabeceiras até a foz, com exceção da classe de risco de erosão muito alto cujo percentual no setor final é maior que no central.

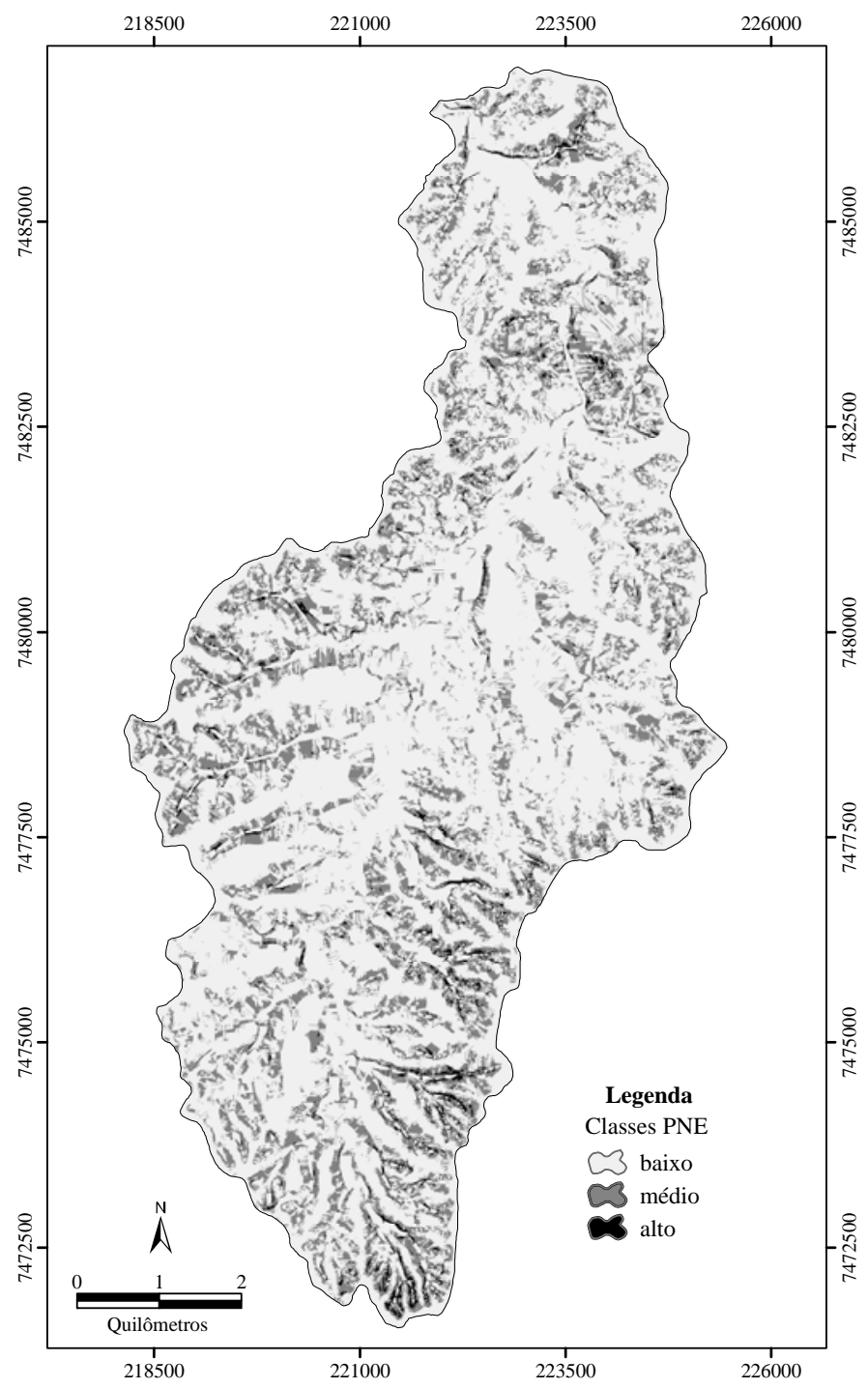

Figura 26 - Mapa do Potencial Natural de Erosão na bacia dos Marins 
Tabela 20. Distribuição do risco de erosão em 2000 nos setores que formam a bacia dos Marins, em janeiro considerando plantio morro abaixo $(\mathrm{P}=1)$

\begin{tabular}{|c|c|c|c|}
\hline \multirow{2}{*}{ Risco de erosão } & \multicolumn{3}{|c|}{ Setores } \\
\hline & Inicial (\%) & Central (\%) & Final (\%) \\
\hline Baixo & 56,1 & 63,5 & 63,6 \\
\hline Médio & 6,2 & 5,5 & 4,9 \\
\hline Alto & 18,1 & 15,3 & 14,5 \\
\hline Muito alto & 19,6 & 15,7 & 17,0 \\
\hline Total & 100,0 & 100,0 & 100,0 \\
\hline
\end{tabular}

\section{Classificação adaptada da capacidade do uso e cobertura do solo}

Como pode-se observar na Figura 27, a classe 1, que corresponde a áreas com limitações baixa a moderada de erosão, predominam com aproximadamente 71,6 \% da área da bacia. A classe 2, que corresponde a terras severamente limitadas por risco de erosão para cultivos intensivos, correspondem a 22,5 \% da área da bacia e a classe 3, com limitações muito severas quanto à erosão, a quase 6 \% da mesma.

Uma consideração a ser feita é que, como esta classificação tem como objetivo analisar apenas as limitações relacionadas à erosão, a profundidade do solo não foi considerada. Assim, algumas áreas de solos litólicos estão classificadas na classe 1, apesar de existirem maiores limitações quanto à profundidade, que poderiam enquadrálas como inadequadas para alguns cultivos quando realizada uma classificação de capacidade de uso do solo que considere a capacidade produtiva do mesmo. 


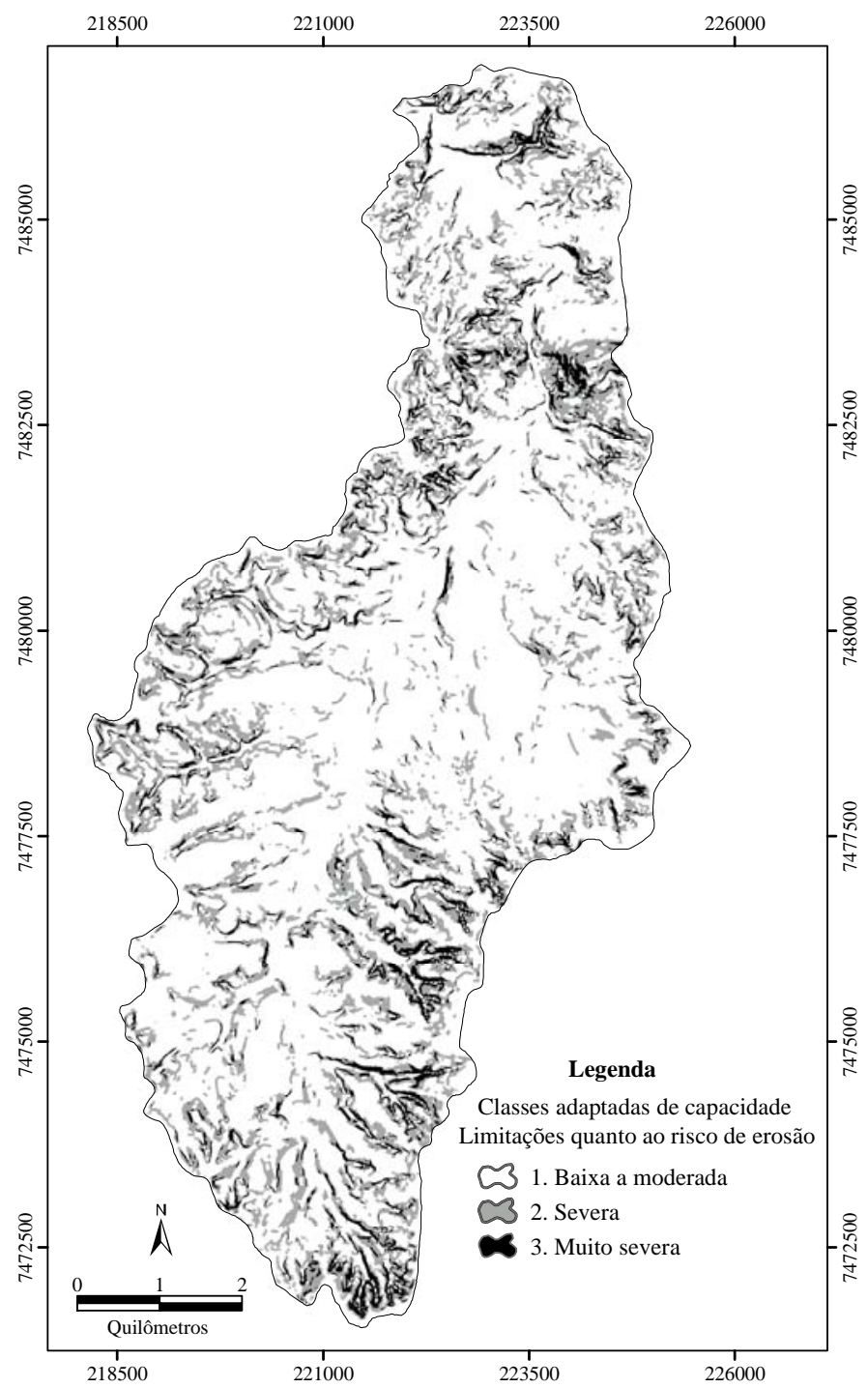

Figura 27 - Distribuição espacial das classes adaptadas da capacidade de uso na bacia dos Marins

\subsection{Análise das mudanças}

Os mapas de uso e cobertura do solo da bacia hidrográfica do ribeirão dos Marins, referentes aos anos de 1962, 1995 e 2000, podem ser observados na Figura 28. Predominam na área de estudo as pastagens e a cultura da cana-de-açúcar. Na Figura 29, pode-se visualizar a evolução temporal das áreas das classes de uso e cobertura do solo na bacia. 

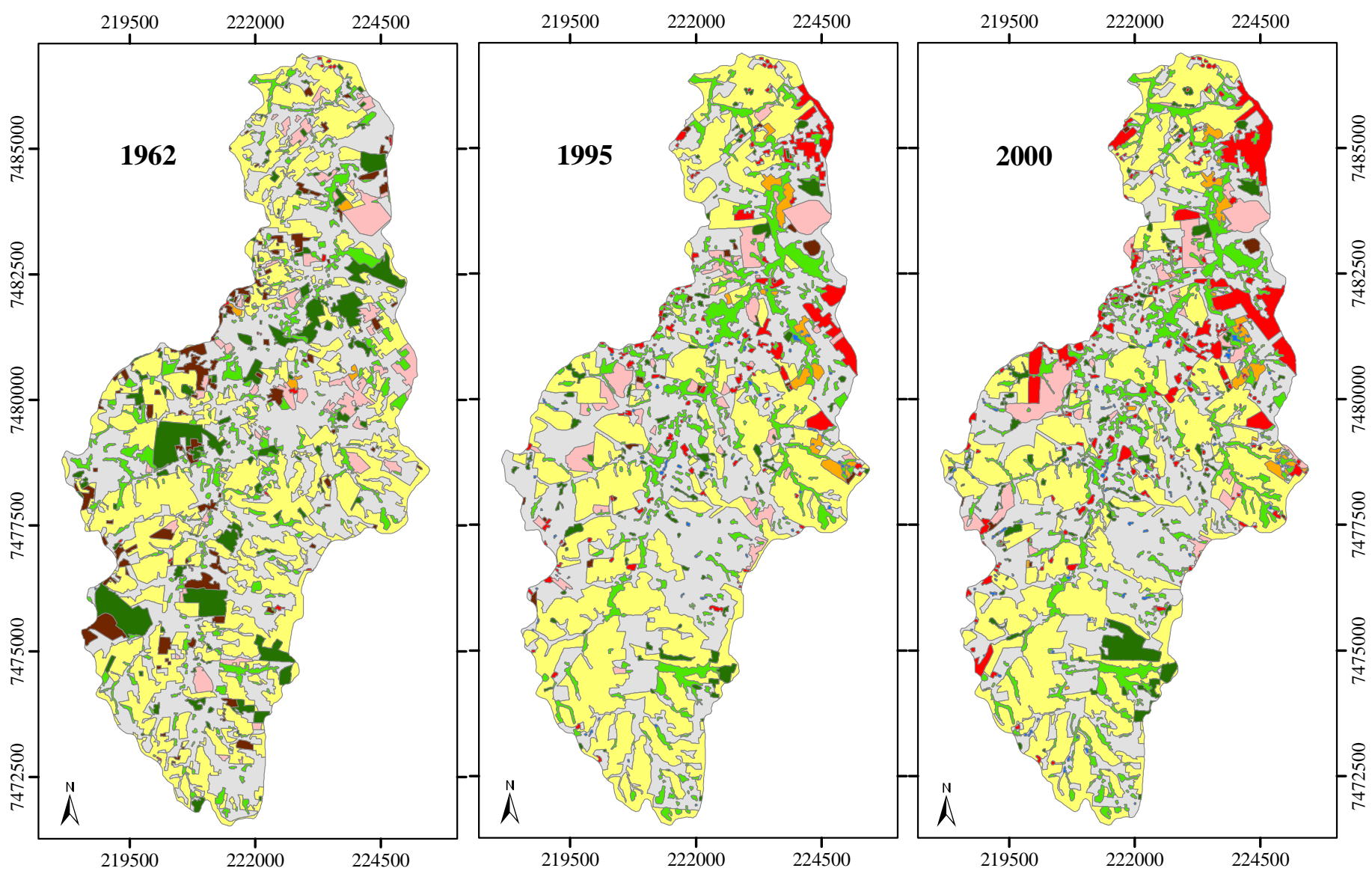

Classes de uso e cobertura do solo
2 Pasto
3 Cana-de-açúcar
3 Floresta plantada
3 Cultura anual
3 Cultura perene
3 Urbanização
Represas ou reservatórios
3 Horticultura

Quilômetros

Figura 28 - Mapas de uso e cobertura do solo da bacia do ribeirão dos Marins referentes aos anos de 1962, 1995 e 2000 


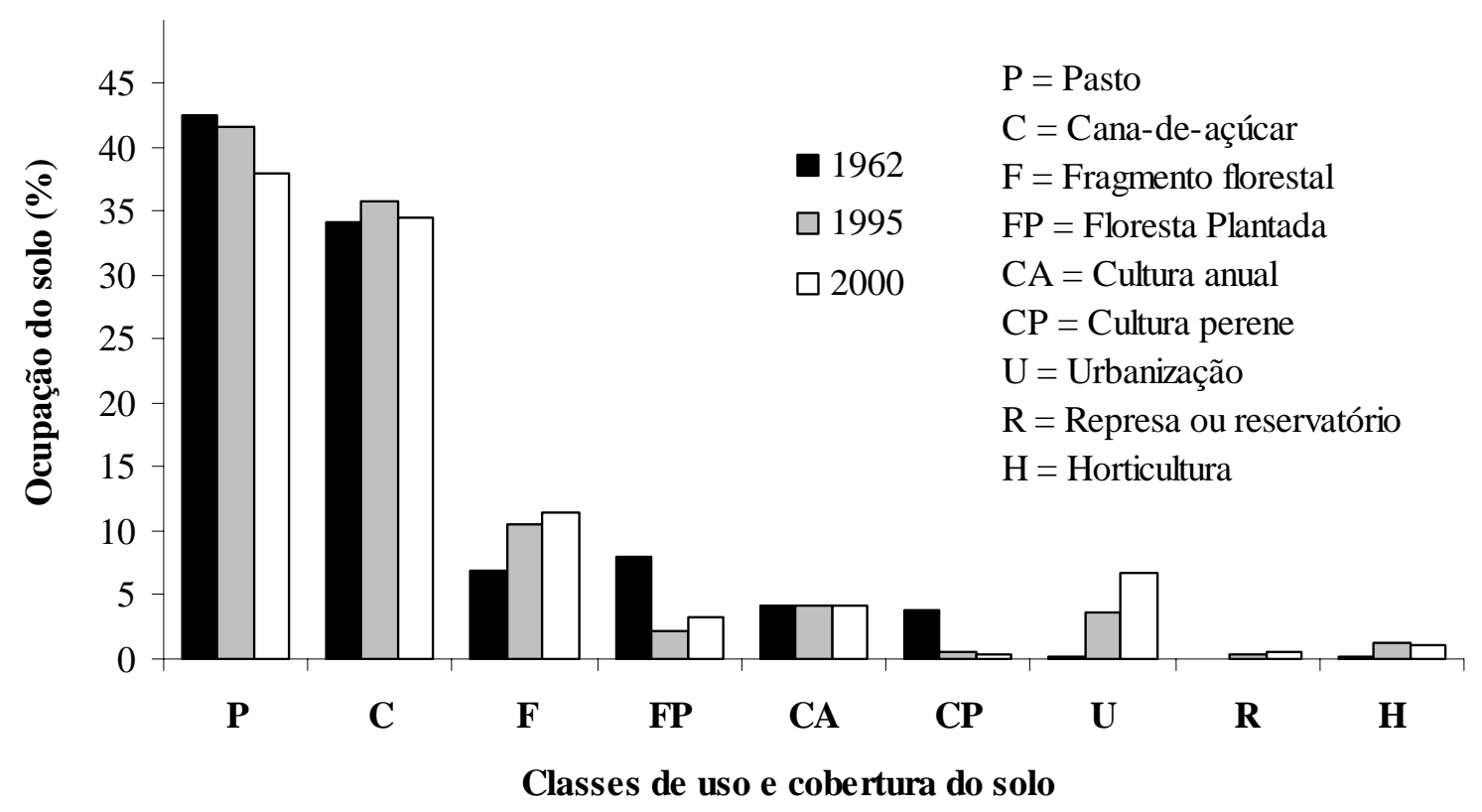

Figura 29 - Distribuição espaço-temporal das classes de uso e cobertura do solo da bacia do ribeirão dos Marins, em 1962, 1995 e 2000

Em 1962, as pastagens representavam 42,4 \% da área da bacia, enquanto a canade-açúcar recobria 34,2 \%, seguida pelos fragmentos florestais (6,9\%) e floresta plantada (8 \%). Em 1995, a área ocupada pelas pastagens passou a representar 41,5 \%, a cana-de-açúcar 35,8 \%, seguida de 10,5 \% de fragmentos florestais e 2,2 \% de floresta plantada. Em 2000, a área ocupada por pastagens representa 38 \%, a cana-de-açúcar 34,6 $\%$, seguida de $11,4 \%$ de fragmentos florestais e 3,3 \% de floresta plantada.

No período de 1962 a 2000, não ocorreram grandes alterações no percentual ocupado pela cana-de-açúcar em relação à área total da bacia. Já neste mesmo período, a pastagem sofreu uma pequena redução de 4,4 \%. O percentual da área da bacia destinada à classe fragmentos florestais aumentou 4,5 \% no mesmo período. A floresta plantada, correspondendo a áreas de silvicultura e reflorestamento, reduziu de $8 \%$ da área da bacia em 1962 para 3,3 \% em 2000. A área referente às culturas anuais permaneceu praticamente estável, enquanto as hortaliças e as represas ou reservatórios aumentaram no período. Com relação às culturas perenes, o percentual destas na bacia diminuiu de 
3,9 \% em 1962 para 0,3 \% em 2000. Um processo de urbanização pode ser verificado na área de estudo nestes 38 anos, representando um aumento de 6,5 \% de áreas urbanizadas.

Com os valores obtidos na matriz (Tabela 21), referente a substituição da área ocupada por cada classe de uso e cobertura do solo, verificamos que no primeiro período estudado, entre 1962 e 1995, os fragmentos florestais substituíram aproximadamente $12,5 \%$ das áreas de pasto e 2,3 \% da cana-de-açúcar. No mesmo período, a cana-deaçúcar substituiu 24,5 \% das pastagens. O inverso também foi constatado, pois 35,3 \% da área de cana-de-açúcar foi substituída por pasto.

Com relação a queda na porcentagem de áreas ocupadas por floresta plantada e culturas perenes entre 1962 e 1995 (Figura 29), constatamos que da área de floresta plantada, 34,3 \% foi substituída por pastagens e 46,1 \% por cana-de-açúcar. Quanto à área ocupada por culturas perenes, 41,2 \% foi substituída por pastagem e 34,6 \% por cana-de-açúcar. No período entre 1995 e 2000, as substituições das áreas de floresta plantada e culturas perenes foram menos expressivas que no período anterior.

Nota-se uma substituição de 8,3 \% de floresta plantada por fragmento florestal no primeiro período estudado. Este percentual representa áreas de reflorestamentos que mesmo que tinham Eucalyptus em 1995 estavam com características de plantio comercial, estando associada a vegetação arbórea natural em estágio avançado de regeneração, apresentando aspecto mais irregular e desuniforme. Estas também representam áreas de silvicultura que foram exploradas e posteriormente abandonadas ou reflorestadas com vegetação nativa, as quais já estavam regenerando e recuperando a área em 1995. Cabe ressaltar também que, um pequeno percentual dessas substituições pode ser resultante do deslocamento de pequenas áreas, as quais não puderam ser corrigidas e podem ter contribuído para este percentual encontrado. 
Tabela 21. Matriz de transição do percentual da área das classes de uso e cobertura do solo nos dois períodos

\begin{tabular}{lccccccccc}
\hline \multicolumn{8}{c}{ Matriz de transição entre 1962 e 1995 } \\
& \multicolumn{7}{c}{ Classes de uso e cobertura do solo em 1995 (\%) } \\
Classes 1962 & Pasto & Cana & $\begin{array}{c}\text { Fragmento } \\
\text { Florestal }\end{array}$ & $\begin{array}{c}\text { Floresta } \\
\text { Plantada }\end{array}$ & $\begin{array}{c}\text { Cultura } \\
\text { Anual }\end{array}$ & $\begin{array}{c}\text { Cultura } \\
\text { Perene }\end{array}$ & Urbanização & Represa ou & Horticultura \\
Pasto & 51,0 & 24,5 & 12,5 & 2,4 & 3,2 & 0,6 & 3,9 & 0,6 & 1,2 \\
Cana-de-açúcar & 35,3 & 53,7 & 2,3 & 1,3 & 3,6 & 0,4 & 2,7 & 0,1 & 0,7 \\
Fragmento Florestal & 30,2 & 10,2 & 48,6 & 3,1 & 3,6 & 0,1 & 2,1 & 0,5 & 1,6 \\
Floresta Plantada & 34,3 & 46,1 & 8,3 & 5,0 & 3,2 & 0,4 & 2,4 & 0,2 & 0,1 \\
Cultura anual & 32,0 & 28,4 & 3,9 & 1,5 & 20,8 & 0,3 & 7,5 & 0,1 & 5,5 \\
Cultura perene & 41,2 & 34,6 & 7,1 & 1,8 & 5,6 & 2,1 & 6,1 & 0,3 & 1,3 \\
\hline
\end{tabular}

Matriz de transição entre 1995 e 2000

Classes de uso e cobertura do solo em 2000 (\%)

\begin{tabular}{lccccccccc} 
Classes 1995 & Pasto & Cana & $\begin{array}{c}\text { Fragmento } \\
\text { Florestal }\end{array}$ & $\begin{array}{c}\text { Floresta } \\
\text { Plantada }\end{array}$ & $\begin{array}{c}\text { Cultura } \\
\text { Anual }\end{array}$ & $\begin{array}{c}\text { Cultura } \\
\text { Perene }\end{array}$ & $\begin{array}{c}\text { Urbanização } \\
\text { Represa ou }\end{array}$ & Horticultura \\
Pasto & 72,2 & 10,8 & 5,6 & 1,6 & 3,0 & 0,2 & 5,6 & 0,6 & 0,4 \\
Cana-de-açúcar & 12,3 & 79,7 & 1,5 & 2,6 & 1,8 & 0,0 & 1,9 & 0,0 & 0,2 \\
Fragmento Florestal & 14,1 & 3,7 & 77,8 & 0,4 & 0,8 & 0,0 & 2,4 & 0,2 & 0,6 \\
Floresta Plantada & 17,2 & 3,3 & 1,4 & 74,7 & 0,5 & 0,0 & 2,2 & 0,3 & 0,2 \\
Cultura anual & 26,0 & 21,0 & 2,0 & 0,4 & 48,2 & 0,0 & 1,5 & 0,1 & 0,9 \\
Cultura perene & 36,3 & 7,4 & 3,5 & 0,4 & 4,2 & 35,8 & 10,2 & 0,0 & 2,2 \\
\hline
\end{tabular}


O percentual das áreas com culturas anuais, embora não tenha apresentado alteração significativa na bacia ao longo do tempo, foi substituído pelos diversos usos, principalmente por pastagens e cana-de-açúcar nos dois períodos estudados, o que confirma que ocorreu permutações de áreas, uma vez que a área desta classe substituiu áreas ocupadas pelos demais usos e coberturas. Os fragmentos florestais também foram substituídos pelas outras classes, principalmente pelo pasto e cana-de-açúcar, apesar de ter aumentado a área desta classe no período de 1962 a 2000 (Tabela 21).

Entre 1995 e 2000, 12,3 \% das áreas de cana-de-açúcar foram substituídos por pastagens, enquanto 10,8 \% das pastagens foram substituídas por cana-de-açúcar, 5,6 \% por fragmento florestal e 5,6 \% pela urbanização.

Com base na matriz de transição, apresentada na Tabela 21, observa-se as grandes substituições que ocorreram na área, as quais são mais relevantes para a análise da paisagem como um todo. No entanto, também pode-se constatar uma constante alteração nesta através da ocorrência de pequenas permutações de áreas.

Ao analisar os índices de métrica da paisagem (Tabela 22), notamos um processo de fragmentação da mesma. No período de 1962 a 2000, observa-se um aumento no número de fragmentos (NF), de 715 para 941, e na densidade de fragmentos (DF), de 12,2 em 1962 para 16,1 fragmentos por quilômetro quadrado em 2000. Os valores da densidade de borda de 1962 e 2000 não sofreram grandes alterações.

Os índices de diversidade de Shannon (IDSH) e de similaridade de Shannon (ISSH) são utilizados na análise da diversidade da paisagem. Quando o valor do IDSH aproxima de 0 , indica que a paisagem é dominada por determinada classe, ou seja, não há diversidade. Quando o ISSH se aproxima de 0, a distribuição da área entre os diferentes tipos de fragmentos torna-se crescentemente desigual. Quando o valor deste índice atinge 1, a distribuição da área entre os diferentes tipos de fragmentos é perfeitamente igual. Portanto, o aumento do IDSH de 1,40 em 1962, para 1,41 em 1995 e 1,50 em 2000 indica uma tendência de distribuição mais proporcional entre as classes de uso e cobertura do solo. Esta tendência também é comprovada pelo aumento do ISSH de 0,639, para 0,641 e 0,684 para os mesmos anos, respectivamente. 
Tabela 22. Índices de métrica da paisagem da bacia do ribeirão dos Marins nos anos de 1962, 1995 e 2000

\begin{tabular}{lccc} 
& \multicolumn{3}{c}{ Bacia do ribeirão dos Marins } \\
ÁREA & $\mathbf{1 9 6 2}$ & $\mathbf{1 9 9 5}$ & $\mathbf{2 0 0 0}$ \\
NF & 58,44 & 58,44 & 58,44 \\
DF & 715 & 749 & 941 \\
DB & 12,24 & 12,82 & 16,10 \\
IDSH & 21,16 & 18,25 & 21,13 \\
ISSH & 1,40 & 1,41 & 1,50 \\
\hline
\end{tabular}

Área $\left(\mathrm{km}^{2}\right)$; NF - número de fragmentos; DF - densidade de fragmentos $\left(\# \mathrm{~km}^{-2}\right)$; DB densidade de borda $\left(\mathrm{km} \mathrm{km}^{-2}\right)$; IDSH - índice de diversidade de Shannon; ISSH - índice de similaridade de Shannon.

Ao analisar os índices de métrica das classes de uso e cobertura do solo (Tabela 23), observa-se a redução na área ocupada pela pastagem. O número de fragmentos (NF) e a densidade de fragmentos (DF) desta classe aumentaram de 1962 para 2000, apresentando uma pequena queda em 1995. O tamanho médio dos fragmentos (TMF) e o comprimento total de borda (BT) reduziram de 1962 a 2000, com um pequeno aumento de 1962 para 1995 no TMF e de 1995 a 2000 no BT. Contudo, ao analisar o período de 1962 a 1995, isoladamente, pode-se constatar a formação de fragmentos maiores pelo aumento no TMF e redução no NF, DF e BT. O inverso pode ser observado no segundo período analisado, de 1995 a 2000, no qual observou-se um aumento no NF, DF e BT e redução no TMF, representando a maior fragmentação das áreas de pasto neste período. 
Tabela 23. Índices de métrica das classes de uso e cobertura do solo dos anos de 1962, 1995 e 2000 da bacia do ribeirão dos Marins

\begin{tabular}{|c|c|c|c|c|c|}
\hline & AC & NF & DF & TMF & BT \\
\hline Pasto 62 & 2477,05 & 65 & 1,11 & 38,11 & 485,80 \\
\hline Pasto 95 & 2427,50 & 59 & 1,01 & 41,14 & 400,02 \\
\hline Pasto 00 & 2220,63 & 91 & 1,56 & 24,40 & 444,11 \\
\hline Cana-de-açúcar 62 & 1998,81 & 125 & 2,14 & 15,99 & 346,07 \\
\hline Cana-de-açúcar 95 & 2093,83 & 71 & 1,21 & 29,49 & 246,97 \\
\hline Cana-de-açúcar 00 & 2019,39 & 73 & 1,25 & 27,66 & 261,84 \\
\hline Fragmento florestal 62 & 404,71 & 267 & 4,57 & 1,52 & 184,31 \\
\hline Fragmento florestal 95 & 613,54 & 245 & 4,19 & 2,50 & 218,98 \\
\hline Fragmento florestal 00 & 664,43 & 305 & 5,22 & 2,18 & 275,82 \\
\hline Floresta plantada 62 & 467,80 & 100 & 1,71 & 4,68 & 88,42 \\
\hline Floresta plantada 95 & 129,86 & 96 & 1,64 & 1,35 & 48,46 \\
\hline Floresta plantada 00 & 193,93 & 100 & 1,71 & 1,94 & 60,61 \\
\hline Cultura anual 62 & 244,88 & 42 & 0,72 & 5,83 & 52,36 \\
\hline Cultura anual 95 & 244,88 & 39 & 0,67 & 6,28 & 44,45 \\
\hline Cultura anual 00 & 240,12 & 27 & 0,46 & 8,89 & 41,50 \\
\hline Cultura perene 62 & 225,76 & 89 & 1,52 & 2,54 & 68,71 \\
\hline Cultura perene 95 & 31,39 & 26 & 0,44 & 1,21 & 11,62 \\
\hline Cultura perene 00 & 16,58 & 15 & 0,26 & 1,11 & 6,30 \\
\hline Urbanização 62 & 9,81 & 16 & 0,27 & 0,61 & 5,91 \\
\hline Urbanização 95 & 210,50 & 108 & 1,85 & 1,95 & 63,36 \\
\hline Urbanização 00 & 392,12 & 162 & 2,77 & 2,42 & 98,17 \\
\hline Represas ou reservatórios 62 & 0,92 & 7 & 0,12 & 0,13 & 1,10 \\
\hline Represas ou reservatórios 95 & 21,07 & 93 & 1,59 & 0,23 & 17,10 \\
\hline Represas ou reservatórios 00 & 31,59 & 146 & 2,50 & 0,22 & 26,60 \\
\hline Horticultura 62 & 14,08 & 4 & 0,07 & 3,52 & 4,02 \\
\hline Horticultura 95 & 71,23 & 12 & 0,21 & 5,94 & 15,55 \\
\hline Horticultura 00 & 65,01 & 22 & 0,38 & 2,95 & 19,55 \\
\hline
\end{tabular}

AC - Área da classe (ha); NF - número de fragmentos; DF - densidade de fragmentos (\# 100ha-1); TMF - tamanho médio dos fragmentos (ha); BT - comprimento total de borda $(\mathrm{km})$. 
As áreas de cana-de-açúcar aumentaram de 1962 para 1995. Neste período, ocorreu uma redução de 125 para 71 no número de fragmentos, da densidade de 2,14 para 1,21 fragmentos por 100 hectares e do comprimento de borda de 346,07 para 246,97 km. Quanto ao TMF, o mesmo aumentou de 16 em 1962 para 29,5 ha em 1995, o que confirma, juntamente com os valores dos outros índices, a formação de fragmentos maiores de cana-de-açúcar. No período entre 1995 e 2000, as áreas com cana-de-açúcar sofreram uma pequena redução. Porém, o NF, DF e BT apresentaram um pequeno aumento e o TMF uma pequena queda. Assim, pode-se constatar a existência de um processo de fragmentação desta classe no segundo período analisado, apesar deste não ser muito expressivo devido às alterações nos valores serem muito pequenas (Tabela 23).

A classe fragmentos florestais aumentou em todo o período de 1962 a 2000, assim como o BT. O NF, DF e TMF aumentaram de 1962 para 2000, porém o NF e DF sofreram uma pequena redução em 1995 e o TMF de 1995 para 2000. No primeiro período, com o aumento da área desta classe e redução de 267 para 245 no número de fragmentos, ocorreu a formação de fragmentos maiores, conforme observa-se no TMF que aumentou de 1,52 para 2,50 ha, apesar do aumento do BT devido ao aumento da área desta classe (AC). No segundo período, pode-se constatar um provável processo de fragmentação da classe devido ao aumento mais ameno da AC, um aumento mais significativo no NF e, conseqüentemente, da DF com redução do TMF.

Um aumento da área destinada a fragmentos florestais pode ser observado devido à revegetação e regeneração. Uma das prováveis causas deste aumento observado, principalmente entre 1962 e 1995, pode estar associada ao Código Florestal vigente (Lei Federal 4771 de 15/09/65, alterada pela Lei Federal 7803 de 18/07/89) e a uma maior fiscalização ambiental no cumprimento deste documento legal, ou seja, das normas que visam à proteção das florestas e demais formas de vegetação. Outros estudos realizados na região de Piracicaba confirmam esta tendência de crescimento florestal (Fiorio et al., 2000; Toledo, 2001).

Cabe ressaltar que outra provável explicação de parte deste aumento é o fato de terem sido consideradas na classificação dos fragmentos florestais desde áreas referentes a capoeiras, coberturas vegetais em desenvolvimento, até áreas cobertas por florestas de 
grande porte. Os referidos aumentos na área da classe fragmento florestal será melhor especificado mais adiante quando mapas de vegetação forem apresentados, nos quais a classe fragmento florestal foi subdividida em duas novas classes, para separar as áreas que não estão em estágio mais avançado de regeneração e para melhor especificar as mudanças verificadas na classe fragmento florestal do mapa de uso e cobertura do solo.

Toledo (2001) também constatou uma redução nas áreas de pastagens nas microbacias dos Ribeirões Piracicamirim e Cabras no período de 1962 a 1995. No mesmo período a área destinada a florestas na microbacia do Piracicamirim passou de 2,2 \% em 1962 para 4,3 \% em 1995 e na microbacia do Cabras, passou de 3,0 \% em 1962 para 10,2 \% em 1994.

Um expressivo aumento da urbanização pode ser constatado pelos valores apresentados na Tabela 23, os quais aumentaram durante o período de 1962 a 2000, os valores da área referente a esta classe, do número de fragmentos (NF), da densidade de fragmentos (DF), do tamanho médio dos fragmentos (TMF) e do comprimento total de borda (BT). Esse aumento, como pode ser observado na Figura 28, ocorreu principalmente no trecho da metade para o final da bacia.

No período de 1962 a 1995, a área de cultivo de hortaliças aumentou aproximadamente 5 vezes. No período de 1995 a 2000 apresentaram uma pequena redução da área. Entretanto, em ambos os períodos o número de hortas aumentou, conforme pode ser observado pelo aumento no NF de 4 em 1962, para 12 em 1995 e 22 em 2000. Cabe ressaltar também, um aumento expressivo na área referente as represas ou reservatórios, o que pode ser verificado pelo aumento na AC, NF e DF (Tabela 23). A presença de um número elevado de represas, açudes, lagos e barreiros foi verificado na área junto a pessoas que trabalham no local e em visita a área de estudo.

Com base na análise dos índices de métrica, observou-se além de um processo de fragmentação da paisagem como um todo, que muitas mudanças estão ocorrendo com relação ao uso e cobertura do solo e que algumas das classes também estão se fragmentando conforme observado em algum dos períodos, como por exemplo a pastagem. 
Contudo, embora determinadas áreas homogêneas, como pastagem e cana-deaçúcar, favoreçam a propagação de alguns distúrbios como do fogo (McGarigal \& Marks, 1995), a fragmentação pode não ser um aspecto positivo ao se considerar a preservação da biodiversidade, a conservação das áreas de preservação permanente e a recuperação de áreas florestais. Áreas florestais fragmentadas sofrem efeitos de borda, fatores externos exercem influência sobre o fragmento alterando as características do ecossistema original presente em uma determinada área. Considerando-se estes aspectos, o ideal seria o estabelecimento de um equilíbrio, com um planejamento ambiental adequado, não favorecendo a propagação de fogo, o risco de incêndios e preservando a biodiversidade.

A distribuição espacial da vegetação em 1962, 1995 e 2000 na bacia do ribeirão dos Marins pode ser visualizada na Figura 30. Observa-se a pequena extensão da vegetação arbórea na bacia, a qual representava 16,4 \% da área da bacia em 1962, 14 \% em 1995 e 16 \% em 2000, incluindo áreas de floresta plantada, regeneração e floresta nativa. As áreas de cobertura florestal são menores do que seria desejável para a manutenção da qualidade ambiental da bacia. Assim, espera-se que as áreas em regeneração sejam um indicativo que áreas estão se recuperando e/ou sendo reflorestadas, aumentando assim o percentual da bacia com floresta em estágio avançado de desenvolvimento. Contudo, proporcionalmente ao total da vegetação, em 1962 o maior percentual refere-se à floresta plantada, enquanto que nos demais anos predomina a vegetação nativa (Figura 31).

Na Figura 31, a dinâmica da vegetação na bacia para os três anos estudados pode ser observada. Um aumento da floresta nativa na bacia no decorrer deste período e um maior percentual de áreas em regeneração no ano de 1995 pode ser constatado.

Os resultados dos percentuais da área da bacia em cada classe de risco de erosão em 1962, 1995 e 2000 apresentados na Tabela 24, mostram claramente a influência da precipitação na perda de solo. Observa-se que o risco de erosão aumenta consideravelmente na época de máxima pluviosidade (mês de janeiro) em relação à de mínima (mês de julho). 


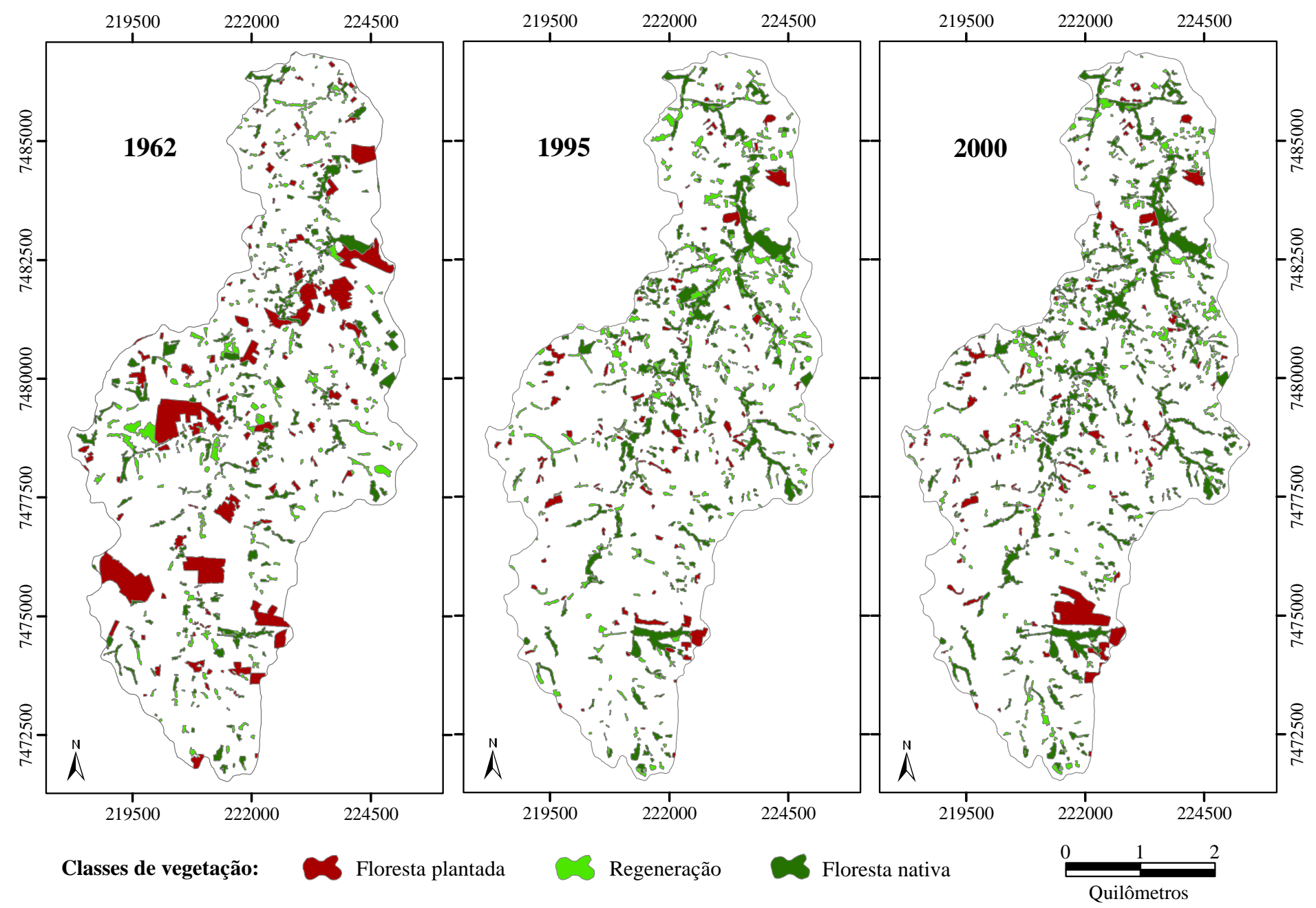

Figura 30 - Mapas de vegetação da bacia do ribeirão dos Marins referentes aos anos de 1962, 1995 e 2000 


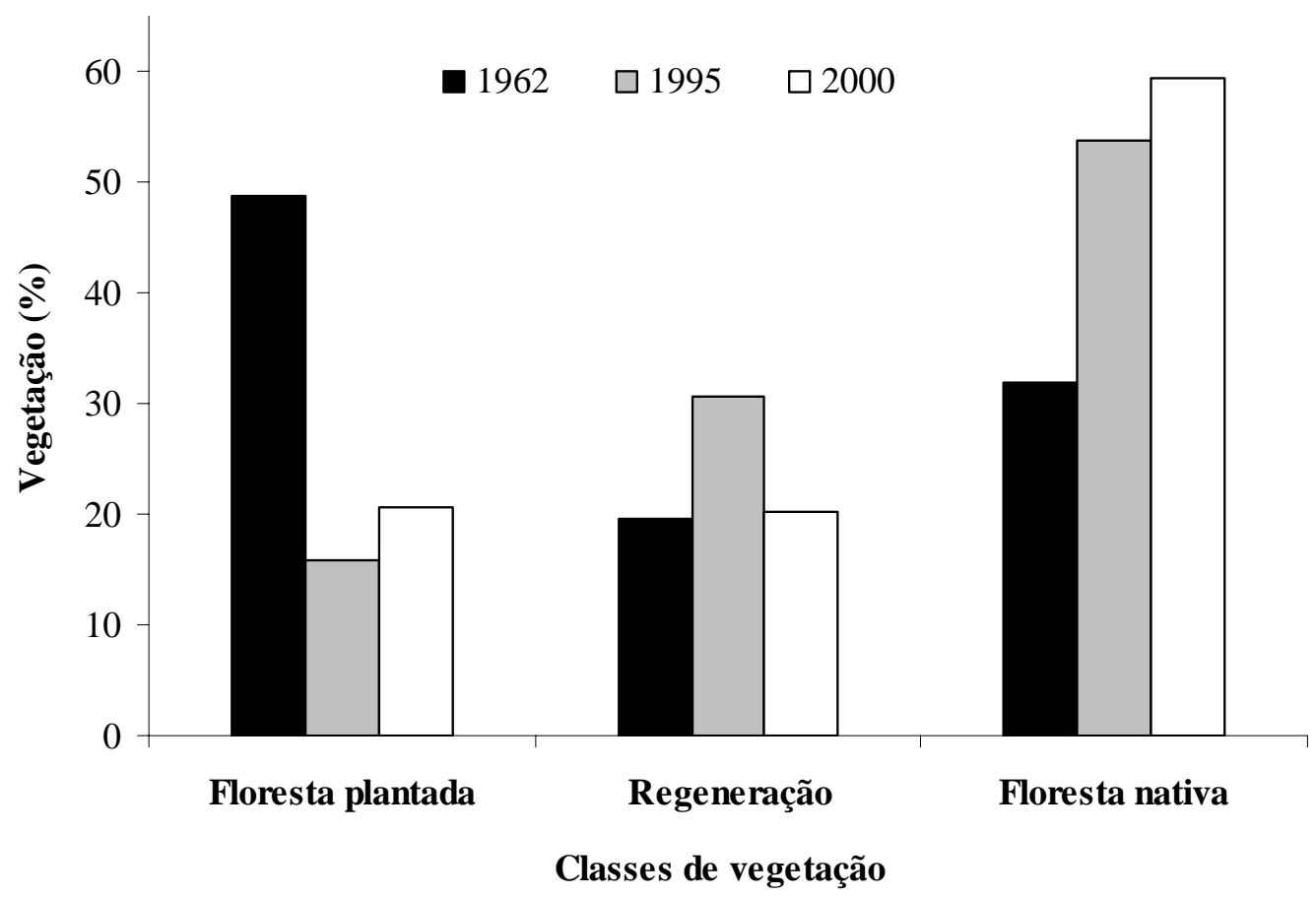

Figura 31 - Distribuição temporal das classes de vegetação na bacia dos Marins em 1962, 1995 e 2000

Durante todo o ano, predominam na bacia áreas com risco de erosão baixo. Em janeiro, mais da metade da área da bacia está enquadrada nesta classe de risco. Porém, uma área significativa da bacia possui riscos de erosão alto e muito alto (Tabela 24). Espacialmente, estas áreas estão concentradas no trecho inicial da bacia em proporções elevadas, principalmente quando consideramos o plantio morro abaixo, conforme podese observar na Figura 32.

Em ambos períodos nota-se que, ao adotar uma prática conservacionista, o risco de erosão é reduzido, aumentando o percentual da área de risco baixo. Observa-se também que, independentemente da prática conservacionista adotada, a precipitação exerce grande influencia no risco potencial de erosão. Assim, além da influencia do fator $\mathrm{P}$, a erosividade (fator R) é responsável pelas grandes variações observadas nos 
percentuais da área da bacia nas classes de risco de erosão para os diferentes períodos (Tabela 24).

Tabela 24. Distribuição percentual das áreas de risco de erosão de 1962, 1995 e 2000 na bacia dos Marins

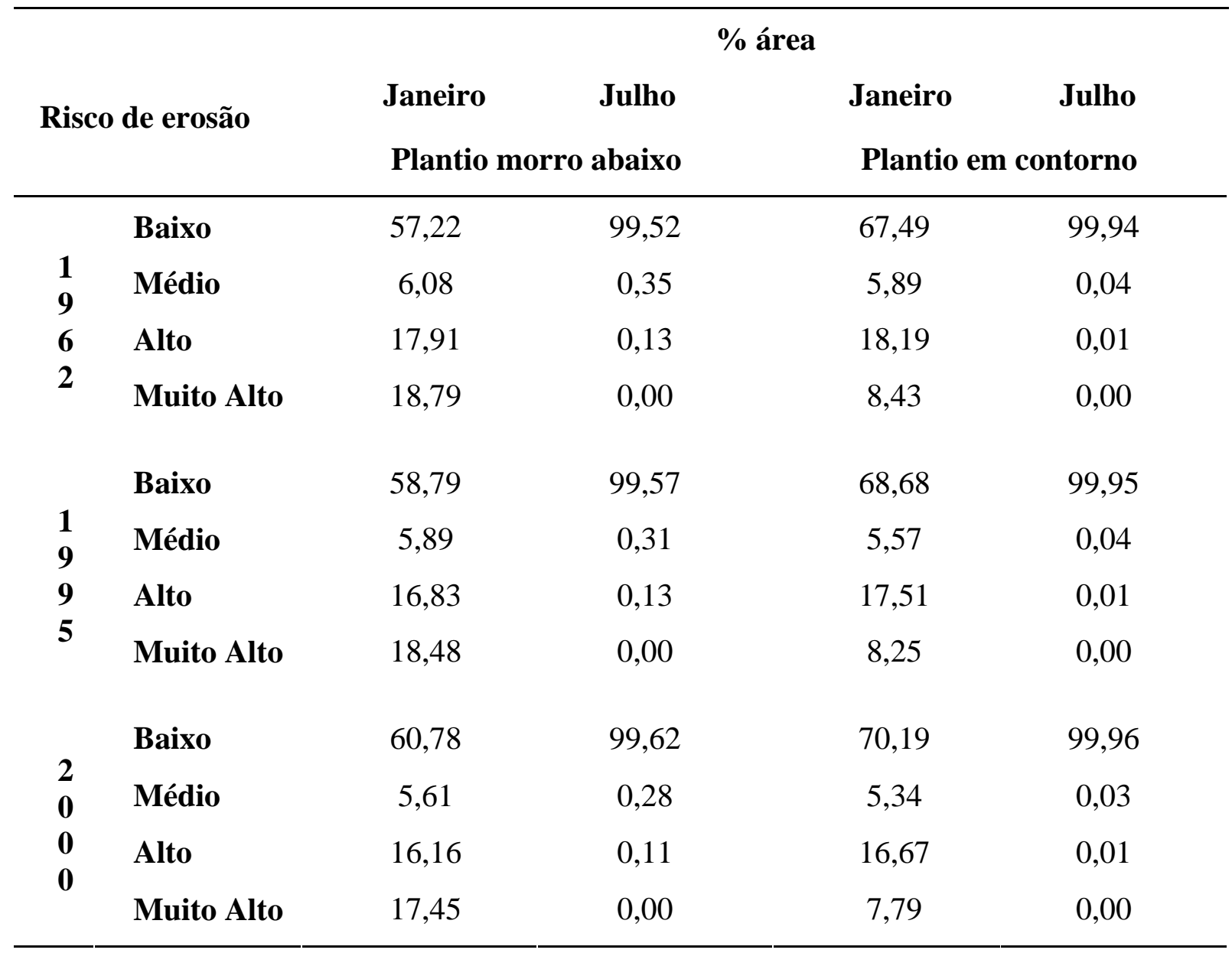

No período seco, mais de 99 \% da área da bacia está enquadrada na classe de risco de erosão baixo nos três anos estudados. As áreas de risco alto são desprezíveis, principalmente ao considerarmos a prática de plantio em contorno, para a qual essas áreas não são visualizadas no mapa elaborado. Nesse período não existem áreas de risco muito alto.

Comparando os percentuais das áreas de risco baixo, alto e muito alto para os diferentes cenários analisados, pode-se constatar a existência de duas situações extremas. 
A pior situação analisada é a referente ao mês de janeiro, com o plantio morro abaixo, apresentando o menor percentual de áreas com risco de erosão baixo (variam de 57 a 61 \% de acordo com o ano) e maior com risco alto a muito alto (33,6 a 36,7 \%). A melhor situação é referente ao mês de julho, com plantio em contorno, a qual apresentou o maior percentual de áreas com risco de erosão baixo, e menor com risco alto a muito alto (Tabela 24).

Com base no levantamento de campo, observamos que a área de estudo possui muitas pastagens degradadas e áreas onde o plantio é feito morro abaixo. Nas áreas onde isso não ocorre, as principais práticas conservacionistas adotadas são o plantio em contorno ou o terraceamento. Conforme observado nos mapas de risco de erosão e como mencionado anteriormente, ao adotar uma prática conservacionista ocorre uma redução no risco de erosão, desde que a prática conservacionista esteja sendo realizada corretamente.

Ao observar os percentuais apresentados na Tabela 24, nota-se que a classe de risco baixo ocupa maior área ao longo do tempo. Conseqüentemente, o oposto ocorreu nas áreas de risco médio, alto e muito alto, cujos percentuais diminuíram de 1962 a 2000. Considerando a análise realizada para o mês de janeiro com plantio morro abaixo, 36,7\% da área da bacia pertencia as classes de risco alto a muito alto de erosão em 1962, 35,3\% em 1995 e 33,6\% em 2000. Assim, pode-se constatar uma situação mais crítica em 1962 no qual o risco de erosão era mais elevado. Esta variação encontrada no risco de erosão nos três anos estudados deve-se às mudanças que ocorreram no uso e cobertura do solo, a qual foi considerada na estimativa de perda de solo através do fator cultural (C) relativo ao uso e manejo do solo. Cabe ressaltar que em 1962 a área de cultura perene, cujo fator C é o mais elevado dentre os considerados, era significativamente maior enquanto as áreas de fragmentos florestais era menor, para as quais o fator C é o menor após o considerado para as represas.

Contudo, além das mudanças dos percentuais da área nas classes de risco, nos mapas de risco potencial de erosão (Figura 32 e Figura 33) observa-se algumas alterações espaciais na distribuição das mesmas. Estas ocorrem devido à dinâmica do uso e cobertura do solo no período estudado, sendo que, mesmo sem aumento das áreas 
com determinados usos, ocorre uma permutação entre as áreas destes. Assim, em alguns locais específicos o risco de erosão aumentou enquanto em outros diminuiu, apenas devido mudanças das regiões onde tais classes de risco estão concentradas.

Com base nos percentuais apresentados na Tabela 25 pode-se constatar que a pastagem e a cultura da cana-de-açúcar predominam em todas as classes de risco de erosão (risco em janeiro e $\mathrm{P}=1$ ) nos três anos estudados, principalmente nas regiões mais críticas. Nota-se que nas classes de risco de erosão baixo e médio, os maiores percentuais correspondem à pastagem, enquanto que nas classes de risco alto e muito alto equivalem a cana-de-açúcar. O fator cultural utilizado na elaboração do mapa de risco de erosão pode ter contribuído para predominar cana-de-açúcar ao invés da pastagem nas classes de risco mais críticas, uma vez que este fator é maior para esta cultura do que para a pastagem. No entanto, a declividade também exerce grande influência nos mapas de risco de erosão elaborados, de modo que as classes mais críticas também representam algumas áreas com maior declividade, as quais quando utilizadas necessitam de práticas conservacionistas mais eficientes para minimizar os processos erosivos, tendo em vista a manutenção da qualidade da água e preservação do ambiente de forma geral.

Os percentuais da urbanização são maiores na classe de risco baixo nos três anos. Os valores correspondentes aos outros usos são maiores nas classes de risco alto e muito alto, nas quais correspondem a mais de $10 \%$ da área destas classes de risco em 1962, 1995 e 2000. Para esta classificação referente aos outros usos foram consideradas as culturas anuais, culturas perenes, represas ou reservatórios e horticultura. A cobertura florestal, ou seja, as classes fragmento florestal e floresta plantada estão presentes apenas nas classes de risco baixo nos três anos (Tabela 25). Cabe ressaltar a importância da cobertura florestal também em áreas com maior risco de erosão, em áreas mais acidentadas, além das áreas de mata ciliar, uma vez que a vegetação ajuda a conter a perda de solo, diminuindo o risco de erosão. 

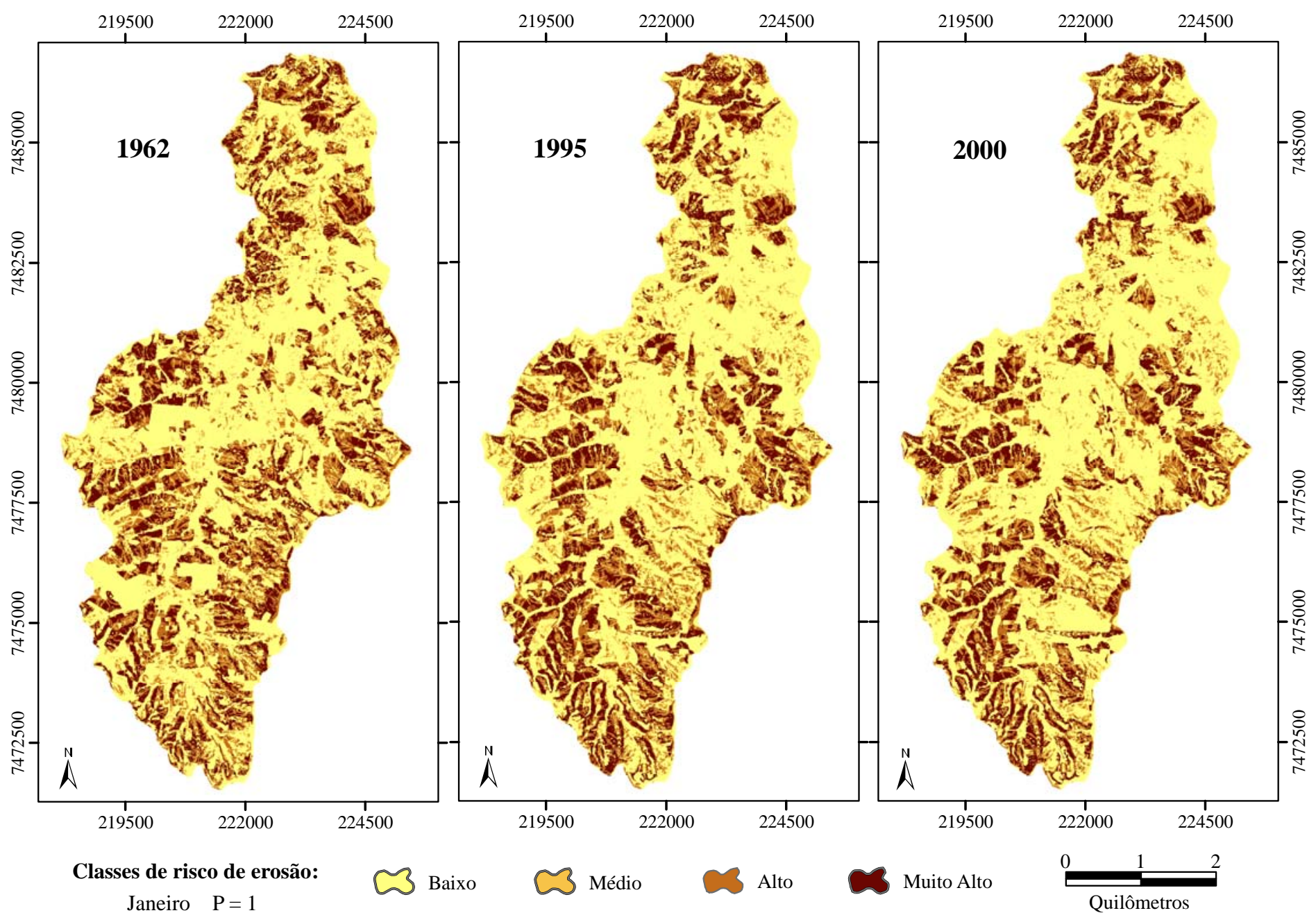

Figura 32 - Mapas de risco de erosão da bacia do ribeirão dos Marins em 1962, 1995 e 2000, em janeiro, com plantio morro abaixo $(\mathrm{P}=1)$ 


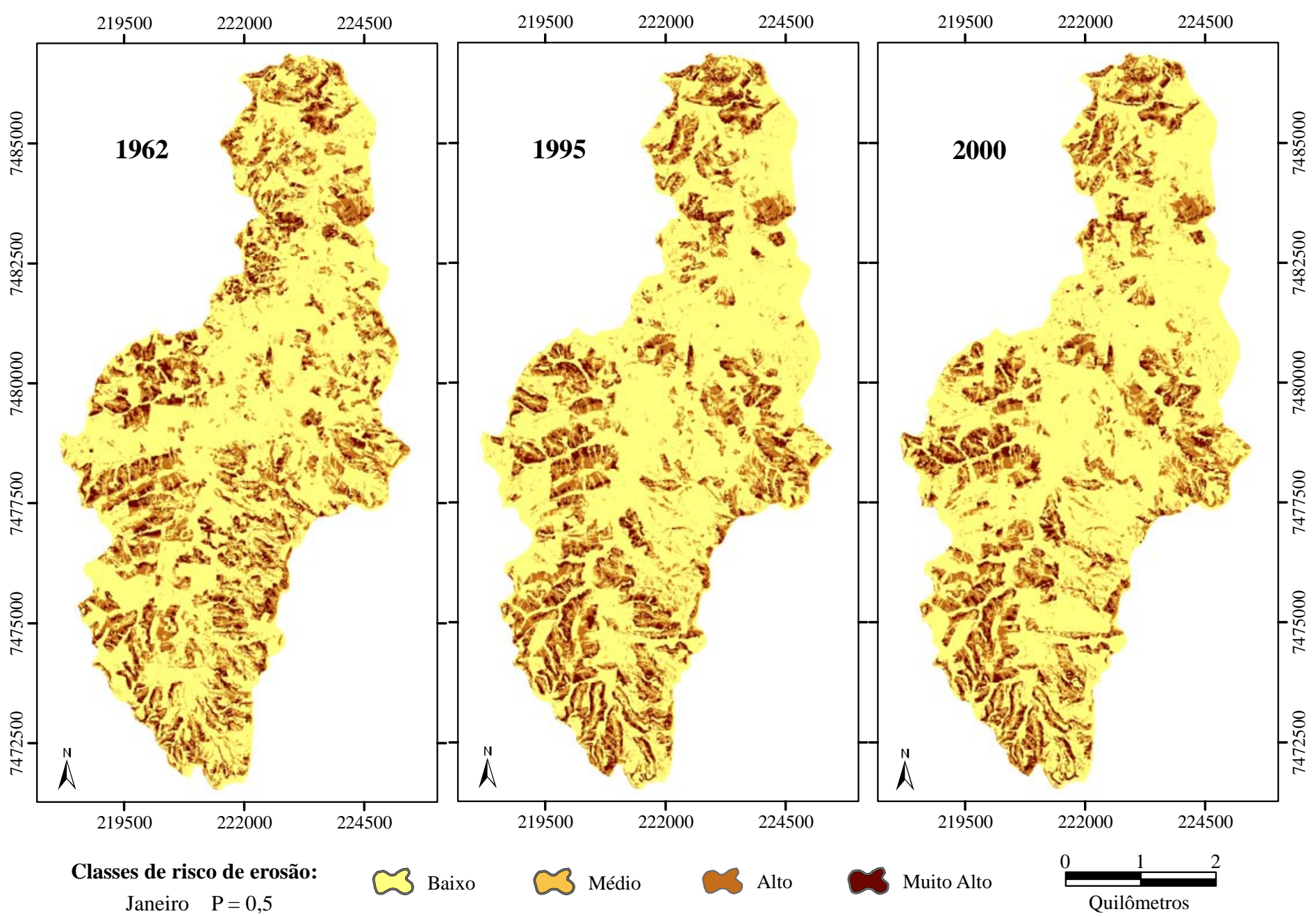

Figura 33 - Mapas de risco de erosão da bacia do ribeirão dos Marins em 1962, 1995 e 2000, em janeiro, com plantio em contorno $(\mathrm{P}=0,5)$ 
Tabela 25. Distribuição percentual do uso e cobertura do solo nas classes de risco de erosão, em janeiro considerando plantio morro abaixo (P=1), em 1962, 1995 e 2000 na bacia dos Marins

\begin{tabular}{llcccc}
\hline \multicolumn{5}{c}{ Classes de risco de erosão (Janeiro; P=1) } \\
& & Baixo & Médio & Alto & Muito Alto \\
& & & \multicolumn{3}{c}{$\%$} \\
\hline & Uso e cobertura do solo & & & \\
\hline & Pasto & 56,73 & 73,67 & 28,39 & 2,19 \\
$\mathbf{1}$ & Cana-de-açúcar & 13,05 & 20,05 & 57,28 & 80,90 \\
$\mathbf{9}$ & Cobertura florestal & 26,12 & 0,00 & 0,00 & 0,00 \\
$\mathbf{6}$ & Urbanização & 0,29 & 0,02 & 0,00 & 0,00 \\
$\mathbf{2}$ & Outros usos & 3,81 & 6,27 & 14,33 & 16,91 \\
& Pasto & 55,36 & 71,05 & 26,80 & 1,61 \\
& Cana-de-açúcar & 13,77 & 21,43 & 61,61 & 87,11 \\
$\mathbf{9}$ & Cobertura Florestal & 21,63 & 0,00 & 0,00 & 0,00 \\
$\mathbf{9}$ & Urbanização & 6,10 & 0,18 & 0,02 & 0,00 \\
$\mathbf{5}$ & Outros usos & 3,13 & 7,33 & 11,58 & 11,28 \\
& & 48,84 & 69,84 & 25,56 & 1,56 \\
& Pasto & 12,85 & 22,65 & 63,13 & 87,56 \\
$\mathbf{2}$ & Cana-de-açúcar & 24,19 & 0,00 & 0,00 & 0,00 \\
$\mathbf{0}$ & Cobertura Florestal & 10,96 & 0,41 & 0,03 & 0,00 \\
$\mathbf{0}$ & Urbanização & 3,16 & 7,10 & 11,29 & 10,89 \\
\hline $\mathbf{0}$ & Outros usos & & & & \\
\hline
\end{tabular}

\subsection{Adequabilidade do uso e cobertura do solo}

Na Figura 34 observa-se a adequabilidade do uso do solo quanto as limitações devido ao risco de erosão em 1962, 1995 e 2000. As áreas de uso inadequado estão localizadas basicamente em regiões com maior declividade, estando parte delas nas cabeceiras da bacia. Cabe ressaltar, que algumas áreas consideradas como adequadas nos 
solos litólicos, devido não oferecer alta limitação quanto à erosão, podem ser inadequadas para alguns usos devido à profundidade.

Considerando o uso adequado, sem oferecer grandes riscos de erosão e que práticas simples de conservação dos solos são adotadas nestas áreas, mais de $80 \%$ do uso e cobertura do solo estava adequado na bacia em 1962, 1995 e 2000 (Tabela 26). Com relação às áreas inadequadas, estas diminuíram ao longo do tempo de 4,8 \% em 1962 para 4,3 \% em 1995 e 4 \% em 2000. As áreas consideradas adequadas com restrições, reduziram de 8,8 \% em 1962 para 8,5 \% em 2000, apresentando um pequeno aumento em 1995 quando correspondia 9 \% da área. Desse modo, considerando que mais de 12 \% da área da bacia corresponde às regiões mais críticas quanto ao risco de erosão, as quais devem apresentar cobertura florestal ou serem utilizadas com restrições adotando práticas conservacionistas mais complexas, o que não ocorre com freqüência na área de estudo, a qualidade da água da bacia pode ser alterada devido a processos erosivos ocasionados pelo uso inadequado ou manejo do solo.

Tabela 26. Distribuição percentual da área da bacia dos Marins nas classes de adequabilidade do uso do solo quanto ao risco de erosão em 1962, 1995 e 2000

\begin{tabular}{lccc}
\hline & \multicolumn{3}{c}{ \% da área na bacia dos Marins } \\
Classes de adequabilidade & $\mathbf{1 9 6 2}$ & $\mathbf{1 9 9 5}$ & $\mathbf{2 0 0 0}$ \\
\hline Adequado & 86,2 & 82,8 & 80,3 \\
Adequado com restrições & 8,8 & 9,0 & 8,5 \\
Inadequado & 4,8 & 4,3 & 4,0 \\
Urbanização e represas ou reservatórios & 0,2 & 4,0 & 7,2 \\
& 100,0 & 100,0 & 100,0 \\
\hline
\end{tabular}



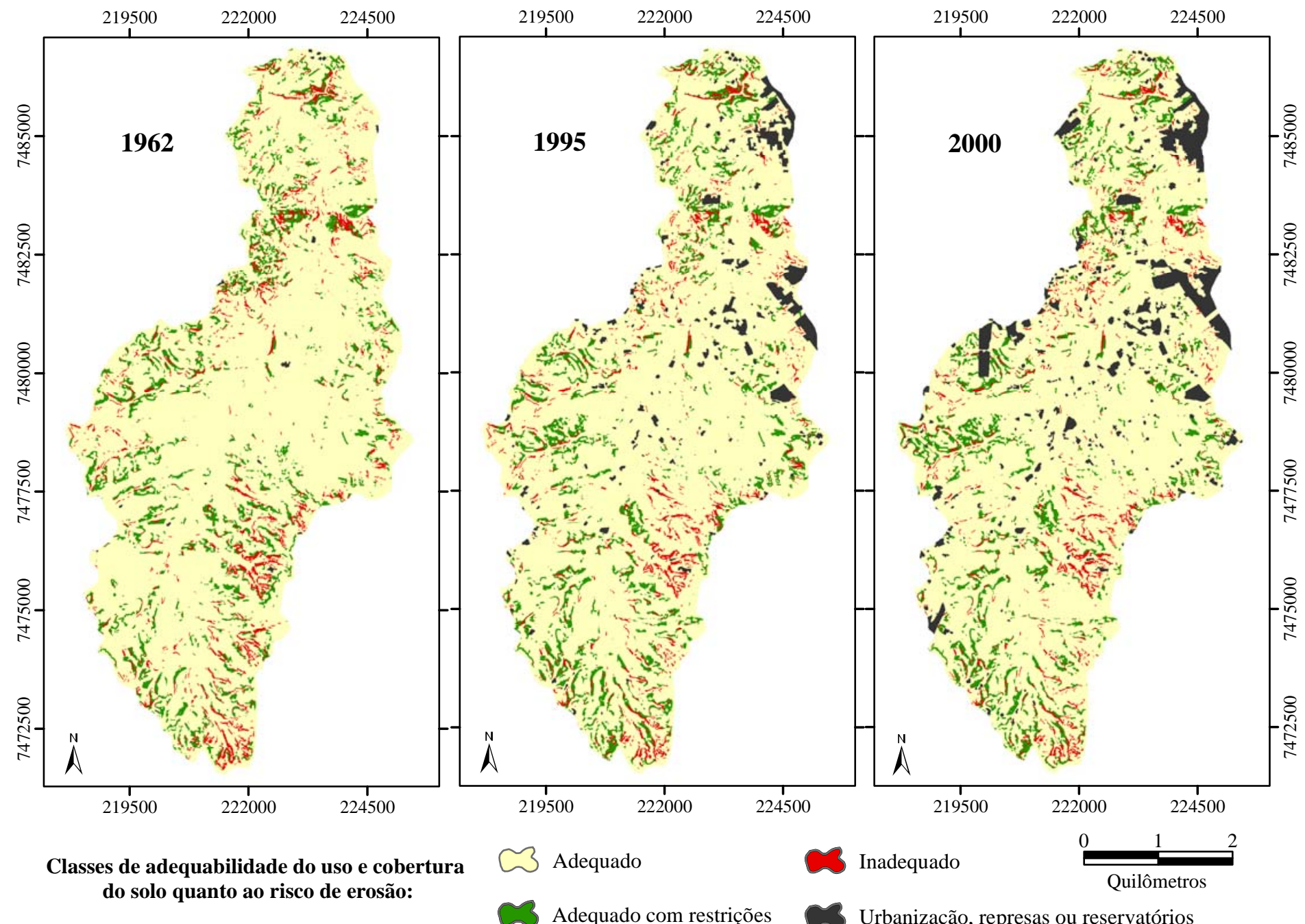

Figura 34 - Mapa de adequabilidade do uso do solo de 1962, 1995 e 2000 quanto ao risco de erosão na bacia dos Marins 
Conforme apresentado na Tabela 27, as áreas inadequadas concentram-se nas cabeceiras e no trecho final da bacia dos Marins, sendo estas correspondentes a 5,1 \% da área do setor inicial e 4,8 \% do setor final em 2000. Os percentuais das áreas consideradas adequadas com restrições também são mais elevados nestes setores. Quanto às áreas adequadas, o maior percentual destas foi encontrado no setor inicial. Entretanto, este não apresenta uma condição melhor que os demais, uma vez que neste setor o percentual das áreas correspondentes à urbanização, represas ou reservatórios é menor que nos demais. Assim, observa-se que apesar do setor inicial da bacia dos Marins ser mais distante da área urbana, este não está em melhores condições de conservação que os demais, não apresentando diferenças significativas quanto a áreas adequadas, apenas menor urbanização.

Tabela 27. Distribuição do percentual das classes de adequabilidade do uso do solo quanto ao risco de erosão em 2000 nos setores que formam a bacia dos Marins

\begin{tabular}{lccc}
\hline Classes de adequabilidade 2000 & \multicolumn{3}{c}{ Setores } \\
& Inicial (\%) & Central (\%) & Final (\%) \\
\hline Adequado & 83,4 & 81,4 & 72,5 \\
Adequado com restrições & 9,4 & 7,1 & 9,9 \\
Inadequado & 5,1 & 2,5 & 4,8 \\
Urbanização e represas ou reservatórios & 2,1 & 9,0 & 12,8 \\
& 100 & 100 & 100 \\
\hline
\end{tabular}

Na Tabela 28 observa-se o percentual referente as áreas das diferentes classes de uso e cobertura do solo nas Áreas de Preservação Permanente (APPs) ao longo dos cursos d'água. Nota-se que a pastagem é o uso e cobertura do solo predominante nas APPs nos três anos estudados. Considerando que as APPs devem cumprir com as funções ambientais determinadas pelo Código Florestal, algumas áreas não estão adequadas, principalmente por não cumprir a função de preservar os recursos hídricos. Nota-se que as áreas com algum tipo de cobertura florestal correspondem a menos de 40 \% nos três anos, sendo que as demais áreas representam 78,5 \% em 1962, 68,8 \% em 1995 e 63,6 \% em 2000. As APPs com cultura da cana-de-açúcar e pasto diminuíram no 
período, enquanto as áreas com culturas anuais aumentaram de 0,98 \% em 1962 para $2,10 \%$ em 2000.

Tabela 28. Uso e cobertura do solo em 1962, 1995 e 2000 nas Áreas de Preservação Permanente ao longo dos cursos d'água na bacia dos Marins

\begin{tabular}{lccc}
\hline $\begin{array}{c}\text { Uso e cobertura do solo nas APPs } \\
\text { ao longo dos cursos d'água }\end{array}$ & $\mathbf{1 9 6 2}$ & $\begin{array}{c}\mathbf{1 9 9 5} \\
\text { \% da APP }\end{array}$ & $\mathbf{2 0 0 0}$ \\
\hline Pasto & 61,63 & 50,16 & 44,26 \\
Cana-de-açúcar & 14,49 & 14,43 & 12,96 \\
Fragmento florestal & 16,67 & 27,73 & 31,50 \\
Floresta plantada & 4,85 & 3,44 & 4,87 \\
Cultura anual & 0,98 & 1,66 & 2,10 \\
Cultura perene & 1,25 & 0,07 & 0,03 \\
Urbanização & 0,00 & 0,94 & 2,15 \\
Represas ou reservatórios & 0,03 & 1,10 & 1,73 \\
Horticultura & 0,10 & 0,48 & 0,40 \\
Total & 100,0 & 100,0 & 100,0 \\
\hline
\end{tabular}

Cabe ressaltar que as APPs devem ser preservadas, sendo que estas podem estar cobertas ou não por vegetação nativa, desde que esteja presente a função ambiental para a qual foram estabelecidas. Assim, se dentre as funções destas áreas estão a de preservar os recursos hídricos, a biodiversidade e proteger o solo, pode-se considerar que após o advento do Código Florestal, as APPs não podem ser desmatadas sem as devidas autorizações, devem ser abandonadas para regeneração natural e não deveriam ser utilizadas com determinados cultivos, os quais, principalmente quando mal manejados, proporcionam um aumento no risco de erosão, contribuindo para o assoreamento dos corpos d'água.

As obras implantadas antes do Código Florestal entrar em vigor estão em situação jurídica consolidada, podendo permanecer do modo que se encontram, não sendo admitidas novas interferências e ampliações na área. Já as áreas não ocupadas devem ser destinadas à regeneração natural ou induzida. Na prática, os órgãos ambientais acabam, em alguns casos, estabelecendo acordos com proprietários de áreas com construções nas APPs, para que eles adotem medidas compensatórias ou paguem 
pela compensação devido a inviabilidade de remanejar as áreas com determinada infraestrutura. Acordos com proprietários de algumas áreas também são realizados para induzir a regeneração, abandonar a área ou remanejar algumas ocupações menores.

A supressão da vegetação em APP somente pode ser autorizada em caso de utilidade pública ou de interesse social, quando inexistir alternativa técnica e locacional ao empreendimento proposto (Art. $4^{\circ}$ do Código Florestal). De acordo com a Medida Provisória 2.166-67 de 2001, as atividades imprescindíveis à proteção da integridade da vegetação nativa e as atividades de manejo agroflorestal sustentável praticadas na pequena propriedade, que não descaracterizem a cobertura vegetal e não prejudiquem a função ambiental da área, são consideradas de interesse social.

Na bacia dos Marins, com 85,5 \% da área localizada na zona rural, pode-se considerar que são poucos os empreendimentos significativos, obras de utilidade pública ou de interesse social que possam ter obtido autorização do órgão ambiental competente para supressão da vegetação. Considerando que as áreas de reserva legal estabelecidas pelo Código Florestal têm que estar averbadas à margem da inscrição de matrícula do imóvel para se obter a autorização para supressão, corte ou exploração da vegetação (conforme Código Florestal e Resolução Conjunta SMA IBAMA/SP Nº2/1994) e, diante de informação, obtida junto ao DEPRN (Departamento Estadual de Proteção dos Recursos Naturais) em Piracicaba no ano de 2003, de que não têm áreas de reserva legal averbadas na bacia dos Marins, pode-se inferir que grande parte das APPs na bacia estão irregulares.

No caso de APPs com atividades agropastoris, estas podem ser consideradas irregulares por não estarem cumprindo com a função ambiental. Nota-se, conforme percentuais apresentados na Tabela 28, que estas atividades estão presentes nas APPs em quantidade significativa. No caso de algumas das interferências nas APP terem sido realizadas antes do Código Florestal, se as mesmas estivessem separadas ou abandonadas para atender a legislação, elas não estariam com determinados usos, com algumas culturas, uma vez que estas áreas teriam passado por um processo de regeneração ou estariam com formação arbórea desenvolvida a qual poderia ser visualizada nas fotografias aéreas. Nas APPs o acesso de animais para obtenção de água 
somente é permitido se não comprometer a regeneração e a manutenção da vegetação nativa.

As áreas de preservação não podem ser exploradas, cultivadas, sendo necessária uma autorização do órgão ambiental estadual competente para fazer qualquer alteração nas mesmas, sendo esta fornecida apenas em alguns casos especificados na lei. Assim, apesar da possibilidade da existência de algumas autorizações para determinadas situações previstas pela lei, diante do elevado percentual de alguns usos nas APPs, com base em observações através das fotografias de áreas com pasto até a margem dos corpos d'água e de cana-de-açúcar que foram colhidas, pode-se afirmar que grande parte da APP da bacia dos Marins está inadequada.

Na Tabela 28 observa-se os percentuais de urbanização nas APPs nos três anos estudados. Um aumento destas áreas no período deve ser mencionado, pois um elevado percentual destas surgiram após o estabelecimento do Código Florestal. Assim, grande parte da urbanização presente nas APPs da bacia dos Marins também pode ser considerada irregular e inadequada.

Com relação a obrigatoriedade de recompor a vegetação nativa nas APPs, esta não existe no texto da lei, exceto nos casos de degradação do meio ambiente ou de licenciamento ambiental. Nestes casos de obrigação de recuperação, esta se dá através de procedimentos administrativos, nos processos de licenciamento ou de autos de infração ambiental aplicados pela Polícia Militar Ambiental, ou através de ação conjunta com o Ministério Público e o Poder Judiciário do Estado de São Paulo. No estado de São Paulo a lei estadual $n^{\circ}$ 9.989/98 trata da obrigatoriedade pelos proprietários da recomposição das APPs, porém esta ainda não foi regulamentada (Francisco et al., 2004).

Assim, como mencionado anteriormente, os proprietários que desmataram antes da lei não são autuados se simplesmente abandonaram a área e não reflorestaram. Entretanto, o proprietário é autuado no caso de estar preparando o solo na APP ou se esta estiver sendo utilizada para culturas. Contudo, a deficiência do sistema de fiscalização deve ser destacado, sendo que a execução desta muitas vezes não ocorre devido ao número insuficiente de funcionários no setor responsável por esta atividade. Portanto, algumas áreas mesmo que irregulares ainda não estão autuadas, principalmente 
por este sistema deficiente, sendo que a fiscalização de determinadas áreas acaba ocorrendo basicamente quando estas são objetos de denúncias.

Segundo Simões et al. (2002), áreas com vegetação nas margens dos corpos d’água, reservatórios e em áreas altas contribuem para a redução dos efeitos da erosão do solo, diminuindo a entrada de sedimentos e poluentes nos corpos d’água. A zona ripária, funciona como um filtro para atrasar, absorver ou purificar os contaminantes escoados antes que eles entrem na superfície d’água.

Na Tabela 29 a situação e composição da vegetação em 1962, 1995 e 2000 nas APPs pode ser observada. Nota-se que a classe da cobertura florestal predominante é a floresta nativa, com 12,6 \% em 1962, 20,3 \% em 1995 e 26,6 \% em 2000. As três classes de cobertura florestal estão adequadas à legislação, no entanto, elas não devem ser exploradas, precisam estar de acordo com as determinações do órgão ambiental, pois o desenvolvimento da vegetação não deve ser prejudicado.

Tabela 29. Vegetação em 1962, 1995 e 2000 nas Áreas de Preservação Permanente ao longo dos cursos d’água na bacia dos Marins

\begin{tabular}{lccc}
\hline $\begin{array}{c}\text { Vegetação nas APPs ao longo } \\
\text { dos cursos d’água }\end{array}$ & $\mathbf{1 9 6 2}$ & $\mathbf{1 9 9 5}$ & $\mathbf{2 0 0 0}$ \\
\% da APP & \\
\hline Floresta plantada & 4,9 & 3,4 & 4,9 \\
Regeneração & 8,3 & 10,6 & 5,9 \\
Floresta nativa & 12,6 & 20,3 & 26,6 \\
Outros usos & 74,3 & 65,7 & 62,7 \\
Total & 100,0 & 100,0 & 100,0 \\
\hline
\end{tabular}

O percentual de áreas em regeneração aumentou de 1962 para 1995, sofrendo posteriormente uma queda de 1995 a 2000 (Tabela 29). Entretanto, o percentual de floresta nativa aumentou neste segundo período. No caso das áreas em regeneração serem conduzidas para a formação de uma vegetação mais densa, espera-se que a situação das APPs na bacia esteja melhor nos próximos anos. 
Nota-se com base nos percentuais apresentados na Tabela 29 e na Figura 35, que a floresta nativa realmente tem aumentado a cada ano de estudo, ou seja, em todo o período. A taxa de aumento da floresta nativa, ao considerarmos o período entre os anos estudados, foi maior no período de 1995 a 2000, fato este extremamente relevante uma vez que a tendência é de aumentar as áreas com cobertura florestal nos próximos anos. Um motivo deste aumento pode ser que os proprietários estão se conscientizando, tentando se regularizar ou adotar medidas compensatórias. No entanto, o oposto também foi observado no aumento da urbanização nas APPs conforme mencionado anteriormente.

Contudo, acredita-se que esta tendência seja mantida uma vez que trabalhos de educação ambiental já foram realizados nas escolas da região da bacia dos Marins e um projeto realizado pela CATI (Coordenadoria de Assistência Técnica Integral) nos últimos anos, principalmente no trecho inicial da bacia, o qual também buscou incentivar a recuperação de mata ciliar dentre as atividades realizadas, além de outros trabalhos que já foram desenvolvidos na região.

Na Figura 35 também podemos observar que apesar deste aumento da vegetação, ainda existem trechos do ribeirão principal e demais corpos d'água desprovidos de vegetação nas APPs, nos quais predominam os outros usos, com cabeceiras dos corpos d'água em meio a pastagem, cana-de-açúcar ou outra cultura, fato este inadequado e indesejável uma vez que pode prejudicar a qualidade da água e favorecer processos erosivos. Cabe ressaltar que com base no mapa de erosão elaborado para o ano de 2000, para janeiro considerando plantio morro abaixo, 76,5 \% da área da APP da drenagem está localizada na classe de risco de erosão baixo, enquanto 9,5 \% na classe de risco alto e 9,2 \% na classe de risco de erosão muito alto. Deste modo, observa-se a existência de áreas com situações críticas quanto ao risco de erosão, as quais deveriam apresentar uma cobertura florestal para reduzir a erosão. 


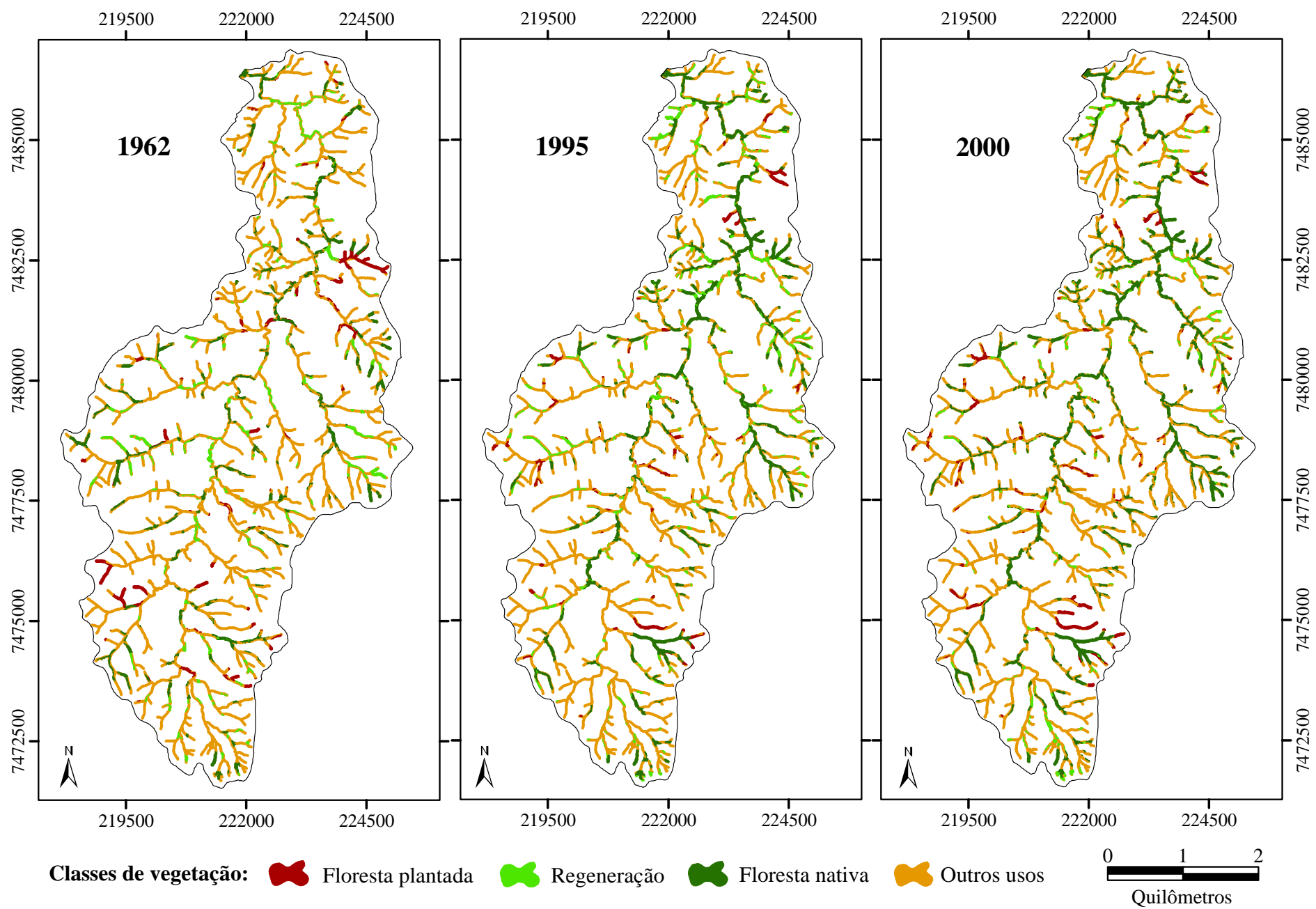

Figura 35 - Distribuição espacial da vegetação em 1962, 1995 e 2000 nas Áreas de Preservação Permanente da bacia dos Marins 
Considerando a necessidade de um planejamento para recuperar as APPs da bacia dos Marins, pode-se estimar um custo médio para recompor a mesma. Numa situação ideal, considerando que as áreas com floresta plantada não estão sendo exploradas ou que no mínimo estejam sendo manejadas adequadamente, pode-se estimar que a área a ser recomposta das APPs ao longo dos cursos d'água é de aproximadamente 696 ha (62,7 \% da APP). Esta área corresponde aos outros usos identificados no mapa de vegetação de 2000 na APP (Figura 35), ou seja, desconsiderando as áreas com algum tipo de cobertura florestal (floresta plantada, floresta nativa e regeneração).

O custo de implantação de um hectare de mata ciliar e manutenção até o terceiro ano de plantio, considerado por Francisco et al. (2004), é de US\$ 1.915,87 levando em consideração uma densidade de 1700 mudas por hectare. Com base numa cotação do valor do dólar de $\mathrm{R} \$ 2,50$, o preço seria de $\mathrm{R} \$ 4.789,68 \mathrm{ha}^{-1}$, ou seja, a estimativa de preço para recuperação florestal dos 696 hectares nas APPs da bacia dos Marins, é de aproximadamente R \$ 3.333.617,3 (US\$ 1.333.445,5).

Estudos, conforme abordado por Francisco et al. (2004), demonstram que o uso de Sistemas Agroflorestais (SAFs), como meta intermediária de manejo, são pertinentes para a recuperação de áreas degradadas e possibilita uma redução dos custos de recuperação das APPs e da Reserva Legal (RL) Florestal. O SAF é um sistema de produção agrossilvicultural diversificado, formado por componentes arbóreos, arbustivos e rasteiros, plantados simultaneamente ou em tempos diferentes. Esta atividade temporária se adequadamente conduzida, poderia ser enquadrada como parte da estratégia de recuperação das APPs e não como exploração da mesma, uma vez que pode favorecer a recuperação da floresta. As espécies exóticas podem ser eliminadas do sistema e o manejo gradativamente reduzido até que, em uma meta de tempo, a cobertura nativa da área a ser recuperada se restabeleça. Diante da necessidade de alternativas que diminuam o custo de recuperação da floresta, o SAF é uma possibilidade auto sustentável de recuperação de APP e restauração da RL. Com o uso do SAF os espaços entre mudas de nativas da restauração são ocupadas, temporariamente por espécies econômicas, visando o controle de espécies competidoras, 
com conseqüente redução do custo da manutenção da restauração (Francisco et al., 2004).

Conforme mencionado anteriormente, de acordo com a Medida Provisória 216667 de 2001, a supressão da vegetação em APP poderá ser autorizada em caso de utilidade pública ou de interesse social. As atividades imprescindíveis à proteção da vegetação nativa, incluindo a erradicação de invasoras, e o manejo agroflorestal sustentável, praticados na pequena propriedade rural ou posse rural familiar são considerados de interesse social. Assim, entende-se que a utilização do SAF no início do processo de recuperação e como meta intermediária de manejo, principalmente na APP exceto nas protetoras de nascentes, é considerada de interesse social e passível de autorização dos órgãos ambientais competentes. O uso deste sistema não causa conflito em relação à legislação florestal vigente, desde que se tenha claro o objetivo principal, que é o de garantir o retorno das funções ecológicas e biológicas desses ecossistemas, aliado à redução dos custos de recuperação da floresta (Francisco et al., 2004).

Considerando a necessidade de manter, na região Sudeste, uma área mínima de $20 \%$ da propriedade com cobertura florestal a título de Reserva Legal (RL), uma análise geral da situação da bacia do ribeirão dos Marins em relação a esta obrigatoriedade pode ser realizada. Apesar da morosidade da obrigação de recompor esta área, no caso da área estar reservada, supõe-se que esta estaria no mínimo com uma vegetação em processo de regeneração. No caso, se for considerada a bacia dos Marins como um todo, desconsiderando a possibilidade de computar no cálculo da RL de algumas propriedades a vegetação nativa existente nas APPs, uma área de aproximadamente 1169 ha deveria ser mantida separada para a Reserva Legal. Com base no mapa de vegetação de 2000, observa-se que aproximadamente $16 \%$ da bacia possui alguma cobertura florestal (regeneração, floresta plantada ou nativa). Desconsiderando o pequeno percentual de 0,3 $\%$ da bacia coberto com cultura perene, a qual poderia ser considerada no cálculo do percentual da RL de algumas pequenas propriedades, o percentual de cobertura florestal ainda está abaixo do estabelecido pela legislação. Desconsiderando a cobertura florestal do mapa de vegetação de 2000 presente nas APPs, aproximadamente 7 \% da área da 
bacia, o percentual de cobertura florestal presente na bacia em 2000 correspondente a RL é de $9 \%$ da área.

Contudo, considerando todos os aspectos apresentados na discussão realizada a respeito da cobertura florestal, cabe ressaltar a importância das práticas de conservação do solo em toda a bacia, além da cobertura florestal nas APPs. A região do entorno também exerce grande influência na qualidade da água da bacia, pois se em determinada região com o uso inadequado, isentas de práticas conservacionistas e com um processo erosivo intenso, a APP estiver com uma cobertura vegetal adequada, a mesma poderá apenas minimizar os efeitos desencadeados pelo uso inadequado do solo da região, mas não poderá conter todo o efeito do carreamento de partículas através do escoamento superficial. Assim, nota-se que esforços também devem ser realizados para que o uso do solo esteja adequado, práticas adequadas sejam adotadas, enfim, para que um manejo sustentável seja realizado em toda a bacia.

Com base na Tabela 30 pode-se constatar claramente o uso inadequado do solo nas classes de risco de erosão (em janeiro considerando plantio morro abaixo) nos três setores que formam a bacia. Nota-se que os maiores percentuais de áreas com cana-deaçúcar foram encontrados na classe de risco de erosão muito alto e no setor inicial, no qual corresponde a 95,9 \% da área da classe de risco muito alto. O setor inicial, o qual deveria estar numa condição de conservação melhor que os demais, por corresponder as cabeceiras e estar mais distante da área urbana, além de não estar preservado, apresenta a pior situação em termos da presença de cana-de-açúcar e pasto nas classes de risco alto e muito alto. Os percentuais de pastagem diminuem nas classes mais críticas e é mais elevado na classe de risco médio. A situação crítica observada a partir dos percentuais apresentados na Tabela 30 permanece nos três setores que formam a bacia. Cabe ressaltar que nas classes de risco muito alto deveria estar presente apenas a cobertura florestal, considerada neste caso como os fragmentos florestais e a floresta plantada, pois problemas sérios podem ocorrer com relação a processos erosivos que podem ser desencadeados no período chuvoso e agravados com o manejo inadequado do solo. 
Tabela 30. Distribuição do uso e cobertura do solo em 2000 nas diferentes classes de risco de erosão, em janeiro considerando plantio morro abaixo, nos três setores que formam a bacia dos Marins

\begin{tabular}{|c|c|c|c|c|c|}
\hline \multirow{2}{*}{\multicolumn{2}{|c|}{2000}} & \multicolumn{4}{|c|}{ Classes de risco de erosão (Janeiro; $P=1$ ) } \\
\hline & & Baixo & Médio & Alto & Muito Alto \\
\hline Setores & Uso e cobertura do solo & \multicolumn{4}{|c|}{$\%$} \\
\hline \multirow{5}{*}{ Inicial } & Pasto & 55,60 & 77,04 & 32,12 & 2,64 \\
\hline & Cana-de-açúcar & 16,71 & 22,19 & 66,46 & 95,93 \\
\hline & Cobertura florestal & 23,61 & 0,00 & 0,00 & 0,00 \\
\hline & Urbanização & 2,83 & 0,03 & 0,00 & 0,00 \\
\hline & Outros usos & 1,26 & 0,74 & 1,42 & 1,43 \\
\hline \multirow{5}{*}{ Central } & Pasto & 49,28 & 65,17 & 19,84 & 0,64 \\
\hline & Cana-de-açúcar & 11,16 & 24,11 & 63,98 & 85,02 \\
\hline & Cobertura Florestal & 22,28 & 0,00 & 0,00 & 0,00 \\
\hline & Urbanização & 12,83 & 0,40 & 0,02 & 0,00 \\
\hline & Outros usos & 4,45 & 10,31 & 16,15 & 14,35 \\
\hline \multirow{5}{*}{ Final } & Pasto & 37,65 & 65,08 & 23,03 & 1,05 \\
\hline & Cana-de-açúcar & 10,26 & 20,78 & 54,15 & 75,33 \\
\hline & Cobertura Florestal & 28,77 & 0,00 & 0,00 & 0,00 \\
\hline & Urbanização & 19,76 & 1,29 & 0,10 & 0,00 \\
\hline & Outros usos & 3,57 & 12,86 & 22,72 & 23,62 \\
\hline
\end{tabular}

Diante dos aspectos apresentados com relação a inadequabilidade do uso, ausência de cobertura florestal em regiões mais vulneráveis e necessidade de um manejo adequado de algumas áreas, um planejamento ambiental deveria ser realizado tendo em vista a conservação dos recursos naturais. A execução deste planejamento teria como objetivo recuperar as áreas inadequadas, estabelecer um uso e manejo sustentável dos recursos, recompor a cobertura florestal em determinadas regiões, minimizar o risco de ocorrência dos processos erosivos e adequar-se a legislação ambiental vigente, restabelendo a função ambiental de algumas áreas características.

Para a recuperação florestal da bacia devem ser consideradas as áreas sem cobertura florestal nas APPs, na classe inadequada do mapa de adequabilidade, na classe 3 adaptada da capacidade de uso com limitação muito severa quanto ao risco de erosão e na classe de risco de erosão muito alto. Estas classes englobam as áreas mais críticas 
devido a declividade, com maior risco de erosão e deslizamento. Alguns aspectos como proximidade das cabeceiras da drenagem e proximidade de outros fragmentos florestais, com o intuito de permitir a integração das áreas com cobertura florestal já existentes, devem ser considerados no caso de necessidade de priorização de áreas para a recuperação.

\subsection{Análise das correlações}

Ao analisar as correlações entre o uso e cobertura do solo e o risco de erosão em 2000 e os parâmetros de qualidade da água, pode-se constatar principalmente a influência da classe de uso e cobertura do solo referente à urbanização. De acordo com a Correlação de Spearman realizada, observou-se uma correlação positiva, altamente significativa, entre o percentual da área com urbanização e os sólidos suspensos totais na cheia $(\mathrm{R}=0,96 ; \mathrm{p}=0,0005)$ e os coliformes fecais na cheia $(\mathrm{R}=0,93 ; \mathrm{p}=0,0025)$. Uma correlação negativa da urbanização com o oxigênio dissolvido na cheia $(\mathrm{R}=-0,89 ; \mathrm{p}=$ 0,0068) também foi observada, sendo a redução dos valores deste parâmetro esperada devido ao maior aporte de matéria orgânica. Cabe ressaltar que esta correlação salienta que o fator de maior influência na qualidade da água do ribeirão dos Marins é o lançamento de efluentes, principalmente referente aos esgotos domésticos. Nota-se que a ocupação urbana interfere na qualidade da água da água do ribeirão devido ao efeito de fontes pontuais, como mencionado anteriormente, e do escoamento superficial urbano que constitui uma fonte não pontual relevante.

Contudo, devido a predominar a influência das áreas urbanas, a qual representa a principal fonte de poluição das águas do ribeirão, principalmente da região central da bacia até a foz, a influência do uso e cobertura do solo não pode ser observada através da correlação realizada. A interferência do uso e ocupação do solo na qualidade da água possivelmente também não pode ser constatada devido, além do motivo especificado acima, a um pequeno número de análises da água. 


\subsection{Sugestões para atividades futuras}

Considerando os diferentes aspectos e situações observadas durante o desenvolvimento deste trabalho e o levantamento de dados realizado, algumas atividades podem ser sugeridas visando a recuperação da bacia dos Marins, a complementação de alguns estudos nela realizados e a inclusão de outros aspectos que poderiam ser analisados mais detalhadamente.

Um planejamento com o intuito de implementar um sistema de tratamento de esgoto na região da bacia e um trabalho de monitoramento da qualidade da água, dando continuidade ao projeto realizado pela Secretaria de Agricultura e Abastecimento de Piracicaba (SEMA), deveria ser executado. Diante da constatação de que a qualidade da água do ribeirão dos Marins não está adequada para a irrigação das hortaliças, questões relacionadas a saúde pública e a situação econômica dos produtores da bacia, os quais dependem da água do ribeirão para a irrigação, também poderiam ser abordadas. Assim, a recuperação seria acompanhada através de um monitoramento apropriado da qualidade da água, mostrando a eficiência do sistema de tratamento implantado e, conseqüentemente, a redução do risco de doenças relacionadas à água contaminada.

Uma análise mais detalhada da contaminação do solo, das águas superficiais e subterrâneas, causada pelo aterro sanitário e por algumas indústrias também poderia ser realizada. Esta teria o intuito de delimitar as áreas da bacia em diferentes níveis de contaminação e verificar a real magnitude dos impactos ocasionados e se estes são reversíveis ou não. Com base nesta análise, ações para diminuir o risco à saúde da população poderiam ser tomadas, de forma a orientar e conduzir a ocupação para que determinados cultivos e atividades não sejam realizadas no local.

Trabalhos relacionados a aspectos sócio-econômicos, a educação, ao consumo racional da água e a descrição florística e fisionômica da vegetação na bacia, abordando questões relacionadas à preservação da biodiversidade e recuperação das áreas degradadas, também poderiam ser desenvolvidos. Na bacia, foi observada a falta 
de análises da concentração de metais pesados, de outros parâmetros de qualidade da água e de perfis de alguns solos localizados nesta para cálculo da erodibilidade.

A análise da influência do uso e cobertura do solo na qualidade da água, nas regiões da bacia menos urbanizadas, poderia ser realizada com um número mais elevado de amostragens da água do ribeirão. A recomposição florestal das áreas críticas da bacia deveria ser desenvolvida em conjunto com as autoridades municipais, de modo a realizar um planejamento que possibilite a execução desta atividade de recuperação de acordo com áreas prioritárias e possibilidades de financiamento, de modo a tornar este plano de trabalho executável diante das diversas circunstâncias.

A maioria das sugestões apresentadas, além de necessitarem do apoio ou fornecimento de dados de órgãos municipais ou estaduais, depende de uma ação conjunta com o poder público, autoridades municipais ou fontes financiadoras. Diante da situação da bacia dos Marins, os planejamentos e atividades realizadas devem ser efetivamente aplicados para a recuperação e conservação ambiental da bacia, de modo a orientar as mudanças que ocorrem na ocupação da mesma. Planos para a regularização das áreas inadequadas e realização das atividades determinadas devem ser elaborados em conjunto com as autoridades municipais, de modo a serem viabilizados e realmente utilizados. 


\section{CONCLUSÕES}

As técnicas de geoprocessamento utilizadas foram eficientes para auxiliar e facilitar o processo de análise necessário para atingir os objetivos deste trabalho. Com base no levantamento e análise realizada, constatou-se que os recursos hídricos da bacia estão sendo degradados, o uso e cobertura do solo está inadequado e um processo de fragmentação está ocorrendo na paisagem.

Diversas fontes potenciais de contaminação dos solos, águas subterrâneas e corpos d'água foram identificadas na bacia do ribeirão dos Marins, o que tem comprometido a qualidade da água utilizada para irrigação de hortaliças, dentre outros usos. A urbanização é o fator de maior influência na qualidade da água da bacia, através de fontes não pontuais e, principalmente, pontuais de poluição. Considerando a situação atual, ações devem ser adotadas no intuito de tratar o esgoto gerado e não somente para desviar o esgoto que estava sendo lançado no ribeirão. Diante do histórico do aterro sanitário, apesar das fontes de poluição do mesmo estarem aparentemente controladas, ele apresenta um elevado potencial de contaminação dos recursos naturais. Assim, o aterro deve ser rigorosamente monitorado mesmo depois de desativado, de modo a diminuir o risco de novos acidentes e não causar mais danos ao meio ambiente.

Na bacia dos Marins predominam a pastagem e a cultura da cana-de-açúcar. Um processo de urbanização foi verificado no período de 1962 a 2000, com aumento na bacia de 6,5\% da área referente a esta classe de uso e cobertura do solo. O percentual da área da bacia ocupada pelos fragmentos florestais também aumentou (4,5\%) nestes 38 anos. Embora a floresta nativa tenha aumentado no período, o percentual desta no setor inicial da bacia é menor, sendo esta região correspondente às cabeceiras, as quais estão mais expostas a ação erosiva. As áreas inadequadas e adequadas com restrições 
determinadas com base no mapa da classificação adaptada de capacidade de uso do solo, as quais representam às regiões mais críticas quanto as limitações devido ao risco de erosão considerando os mapas de uso e cobertura do solo, correspondem a mais de $12 \%$ da bacia e estão diminuindo ao longo dos anos, apesar de serem encontradas em percentuais mais elevados nos setores inicial e final da bacia.

O uso e cobertura do solo está inadequado em grande parte das Áreas de Preservação Permanente (APPs) ao longo dos cursos d'água da bacia dos Marins, principalmente por não cumprir a função ambiental determinada pelo Código Florestal. Nestas, um aumento da urbanização está ocorrendo embora os fragmentos florestais também estejam aumentando. As áreas de pastagens predominam nas APPs em 1962, 1995 e 2000, apesar de estarem diminuindo. Assim, este aumento de fragmentos florestais nas APPs deve ser mantido e um trabalho de recomposição da mata ciliar deve ser realizado para recuperar os diversos trechos na margem do ribeirão principal e nas cabeceiras dos corpos d'água que estão desprovidos de vegetação. As cabeceiras correspondem as áreas em condições mais críticas na bacia com relação ao uso do solo nas APPs, as quais além de apresentarem os menores percentuais de fragmento florestal, apresentam os maiores percentuais de pasto e cana-de-açúcar.

Um processo de fragmentação da paisagem como um todo está ocorrendo na área, o que em determinadas regiões pode ser um fator indesejável, tendo em vista a preservação da biodiversidade e recuperação de florestas, uma vez que áreas florestais fragmentadas sofrem efeitos de borda, fatores externos exercem influência sobre o fragmento alterando as características do ecossistema original presente em uma determinada área. Assim, um planejamento adequado deve ser realizado para se estabelecer um equilíbrio no ambiente considerando todos estes aspectos.

Situações irregulares com relação à legislação ambiental e a preservação ambiental, tendo em vista a sustentabilidade do ecossistema, foram encontradas na bacia. Considerando os diversos aspectos considerados neste trabalho, fica clara a necessidade de uma política ambiental eficiente, com um planejamento ambiental adequado que oriente a ocupação da bacia e a adoção de medidas para a recuperação da mesma. 


\section{REFERÊNCIAS BIBLIOGRÁFICAS}

ANDERSON, J.R.; HARDY, E.E.; ROACH, J.T.; WITMER, R.E. Sistema de classificação do uso da terra e do revestimento do solo para utilização com dados de sensores remotos. Rio de Janeiro: IBGE, 1976. 78p.

BENEDITO, C. O município e o meio ambiente: das áreas de preservação permanente. Piracicaba, 2001. 29 p. Monografia (Trabalho de Conclusão de Curso) - Escola de Engenharia de Piracicaba, Fundação Municipal de Ensino de Piracicaba.

BERTONI, J.; LOMBARDI NETO, F. Conservação do solo. 3.ed. São Paulo: Ícone, 1990. $355 \mathrm{p}$.

BORGES, M.H.; PFEIFER, R.M.; DEMATTÊ, J.A.M. Evolução e mapeamento do uso da terra, através de imagens aerofotogramétricas e orbitais em Santa Bárbara D’Oeste (SP). Scientia Agrícola, v.50, n.3, p. 365-71, 1993.

BRAGA, B.; HESPANHOL, I.; CONEJO, J.G.L.; BARROS, M.T.L.; SPENCER, M.; PORTO, M.; NUCCI, N.; JULIANO, N.; EIGER, S. Introdução à Engenharia Ambiental. São Paulo: Prentice Hall, 2002. 305 p.

BRANCO, S.M.; ROCHA, A.A. Ecologia: educação ambiental. São Paulo: CETESB Companhia de Tecnologia de Saneamento Ambiental, 1980. 260 p.

BRASIL. Lei no 4771, de 15 de setembro de 1965. Institui o novo Código Florestal.

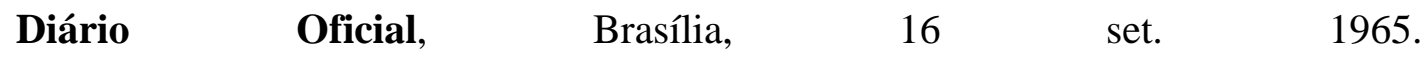
http://www.presidencia.gov.br/ccivil_03/Leis/L4771.htm. (20 jul. 2004).

BRASIL. Lei $n^{\circ}$ 7803, de 18 de julho de 1989 . Altera a redação da Lei $n^{\circ}$ 4.771, de 15 de setembro de 1965. Diário Oficial, Brasília, 20 jul. 1989. http://www.lei.adv.br. (16 jan. 2005) 
BRASIL. Decreto n ${ }^{\circ}$ 3179, de 21 de setembro de 1999. Dispõe sobre a especificação das sanções aplicáveis às condutas e atividades lesivas ao meio ambiente, e dá outras providências. http://www.planalto.gov.br/ccivil_03/decreto/D3179.htm. (20 jul. 2004)

BRASIL. Portaria do Ministério da Saúde $n^{0}$ 1469, de 29 de dezembro de 2000. Estabelece os procedimentos e responsabilidades relativos ao controle e vigilância da qualidade da água para consumo humano e seu padrão de potabilidade, e dá outras providências. Diário Oficial, Brasília, 10 jan. 2001. http://elegis.bvs.br/leisref/public/showAct.php. (10 fev. 2004)

BRASIL. Medida Provisória n ${ }^{\circ}$ 2166-67, de 24 de agosto de 2001. Altera os arts. $1^{\circ}, 4^{\circ}$, 14, 16 e 44, e acresce dispositivos à Lei no 4.771, de 15 de setembro de 1965, que institui o Código Florestal. Diário Oficial, Brasília, 25 ago. 2001. http://www.planalto.gov.br/ccivil_03/MPV/2166-67.htm. (20 jul. 2004)

CABO, A.R.; RODRIGUEZ, J.M.M.; BRECANSIN, R.B.; MARINHO, V.L.F. Laudos periciais em depredações ambientais. In: MAURO, C.A. (Coord.) Laudos e perícias em depredações ambientais. Rio Claro: Laboratório de Planejamento Regional, DPR, IGCE, Unesp, 1997. p. 15-26.

CARPENTER, S.R.; CARACO, N.F.; CORRELL, D.L.; HOWARTH, R.W.; SHARPLEY, A.N.; SMITH, V.H. Nonpoint pollution of surface waters with phosphorus and nitrogen. Ecological Applications, v.8, n.3, p. 559-568, 1998.

CASTRO, A.G. Técnicas de sensoriamento remoto e sistemas geográficos de informações no estudo integrado de bacias hidrográficas. São José dos Campos, 1992. 145 p. Dissertação (Mestrado) - Instituto Nacional de Pesquisas Espaciais.

CERRI, C.E.P. Mapeamento das áreas de risco de erosão dos solos da bacia do rio Piracicaba, utilizando geoprocessamento. Piracicaba, 1999. 89 p. Dissertação (Mestrado) - Escola Superior de Agricultura "Luiz de Queiroz”, Universidade de São Paulo.

COMPANHIA DE TECNOLOGIA DE SANEAMENTO AMBIENTAL - CETESB.

Relatório de qualidade das águas interiores do estado de São Paulo 2000. São Paulo: CETESB, 2001. 227 p. 
COMPANHIA DE TECNOLOGIA DE SANEAMENTO AMBIENTAL - CETESB. Processo 21/00438/00 referente à Cooperativa dos Produtores de Leite de Piracicaba e Região - COPLEPI. Piracicaba.

COMPANHIA DE TECNOLOGIA DE SANEAMENTO AMBIENTAL - CETESB.

Processos 21/00462/00 e PA 0200/96 referentes a Agritec Indústria Brasileira de Herbicidas Ltda. Piracicaba.

COMPANHIA DE TECNOLOGIA DE SANEAMENTO AMBIENTAL - CETESB.

Processos 21/00298/96, 21/00770/01, 21/00441/01, 21/00480/01, 21/00770/01, 21/00876/02, 21/00121/03, 21/00122/03, 21/00349/03 e 21/00526/03 referentes à

Catálise Indústria e Comércio de Metais Ltda. Piracicaba.

COMPANHIA DE TECNOLOGIA DE SANEAMENTO AMBIENTAL - CETESB.

Processos 21/00272/90, 21/00112/92, 21/00113/92, 21/00636/98, 21/00171/99, 21/00035/02, 21/00095/03 e PA 0165/88, 0267/96, 058/02, 031/03 referentes ao Aterro Sanitário do Pau Queimado. Piracicaba.

CONSELHO NACIONAL DO MEIO AMBIENTE - CONAMA. Resolução $\mathrm{n}^{\circ}$ 20, de 18 de junho de 1986. Classificação das águas, doces, salobras e salinas do Território Nacional. Diário Oficial, Brasília, $30 \quad$ jul. 1986. http://www.mma.gov.br/port/conama. (16 jan. 2004)

CONSELHO NACIONAL DO MEIO AMBIENTE - CONAMA. Resolução nº 302, de 20 de março de 2002. Dispõe sobre os parâmetros, definições e limites de Áreas de Preservação Permanente de reservatórios artificiais e o regime de uso do entorno. Diário Oficial, $\quad$ Brasília, $13 \quad 2002$. http://www.mma.gov.br/port/conama/index.cfm. (10 mar. 2005)

CONSELHO NACIONAL DO MEIO AMBIENTE - CONAMA. Resolução nº 303, de 20 de março de 2002. Dispõe sobre parâmetros, definições e limites de Áreas de Preservação Permanente. Diário Oficial, Brasília, 13 maio 2002. http://www.mma.gov.br/port/conama/index.cfm. (10 mar. 2005) 
CONSELHO NACIONAL DO MEIO AMBIENTE - CONAMA. Resolução nº 357, de 17 de março de 2005. Dispõe sobre a classificação dos corpos de água e diretrizes ambientais para o seu enquadramento, bem como estabelece as condições e padrões de lançamento de efluentes. Diário Oficial, Brasília, 18 mar. 2005. http://www.mma.gov.br/port/conama/index.cfm. (17 mar. 2005)

COORDEnAdORIA DE ASSISTÊnCIA TÉCNICA INTEGRAL - CATI. Programa estadual de microbacias hidrográficas: plano da microbacia hidrográfica do Ribeirão dos Marins. Piracicaba: Casa da Agricultura de Piracicaba - CATI / SAA, 2001. 70 p.

CRÓSTA, A.P. Processamento digital de imagens de sensoriamento remoto. Campinas: IG/UNICAMP,1992. $170 \mathrm{p}$.

DENARDIN, J.E. Erodibilidade do solo estimada por meio de parâmetros físicos e químicos. Piracicaba, 1990. 114 p. Tese (Doutorado) - Escola Superior de Agricultura “Luiz de Queiroz”, Universidade de São Paulo.

DEPARTAMENTO DE ÁGUAS E ENERGIA ELÉTRICA - DAEE. Plano estadual de recursos hídricos: manual de cálculo das vazões máximas, médias e mínimas nas bacias hidrográficas do Estado de São Paulo. São Paulo: DAEE, 1994. 63 p.

DESMET, P.J.J.; GOVERS, G. A GIS procedure for automatically calculating the USLE LS factor on topographically complex landscape units. Journal of Soil and Water Conservation, v.51, n.5, p.427-433, set./out. 1996.

DEVOL, A.H.; FORSBERG, B.R.; RICHEY, J.E.; PIMENTEL, T.P. Seasonal variation in chemical distributions in the Amazon (Solimões) River: a multiyear times series. Global Biogeochemical Cycles, v.9, n.3, p.307-328, 1995.

DONZELI, P.L.; VALÉRIO FILHO, M.; PINTO, S.A.F.; NOGUEIRA, F.P.; ROTTA, C.L.; LOMBARDI NETO, F. Técnicas de sensoriamento remoto aplicadas ao diagnóstico básico para planejamento e monitoramento de microbacias hidrográficas. In: LOMBARDI NETO, F.; CAMARGO, O.A. Microbacia do córrego São Joaquim (Município de Pirassununga, SP). Campinas: Instituto Agronômico, 1992. p.91-119. (Documentos, 29). 
EMPRESA BRASILEIRA DE PESQUISA AGROPECUÁRIA - EMBRAPA. Sistema brasileiro de classificação de solos. Brasília: Centro Nacional de Pesquisa de Solos, 1999. $412 \mathrm{p}$.

FIORIO, P.R.; DEMATTÊ, J.A.; SPAROVEK,G. Cronologia e impacto ambiental do uso da terra na microbacia hidrográfica do Ceveiro, em Piracicaba, SP. Pesquisa Agropecuária Brasileira, v.35, n.4, p.671-679, 2000.

FORMAN, R.T.T. Land Mosaics: the ecology of landscapes and regions. Cambridge: Cambridge University Press, 1997. 632 p.

FRANCISCO, C.E.S.; ZAKIA, M.J.B.; TORRES, R.B.; COELHO, R.M. Recuperação de áreas de preservação permanente e reserva legal com a utilização de sistemas agroflorestais: aspectos técnicos e legais (compact disc). In: CONGRESSO DE MEIO AMBIENTE DE PAULÍNIA E REGIÃO METROPOLITANA DE CAMPINAS, 1, Paulínia, 2004. Trabalho completo. Paulínia: Paulínia e RMC, 2004.

FROHN, R.C. Remote sensing for landscape ecology: new metric indicators for monitoring, modeling and assessment of ecosystems. New York: Lewis Publishers, 1998. 99 p.

FUJIHARA, A.K. Predição de erosão e capacidade de uso do solo numa microbacia do oeste paulista com suporte de geoprocessamento. Piracicaba, 2002. 118 p. Dissertação (Mestrado) - Escola Superior de Agricultura “Luiz de Queiroz”, Universidade de São Paulo.

GERGEL, S.E.; TURNER, M.G. Learning landscape ecology: a practical guide to concepts and techniques. New York: Springer-Verlag, 2002. 316 p.

GIBOSHI, M.L. Desenvolvimento de um sistema especialista para determinar a capacidade de uso da terra. Campinas, 1999. 93 p. Dissertação (Mestrado) Faculdade de Engenharia Agrícola, Universidade Estadual de Campinas. 
GOBIN, A.; GOVERS, G.; JONES, R.; KIRKBY, M.; KOSMAS, C. Assessment and reporting on soil erosion. Copenhagen: European Environment Agency, 2003. 103 p. http://www.environmental-center.com/articles/article1400/ tech_94.pdf. (25 abr. 2005). (Technical Report)

GUERRA, A.J.T.; SILVA, A.S.; BOTELHO, R.G.M. (Org.) Erosão e conservação dos solos: conceitos, temas e aplicações. Rio de Janeiro: Bertrand Brasil, 1999. 340p.

HICKEY, R.; SMITH, A.; JANKOWSKI, P. Slope length calculations from a dem within ARC/Info grid. Computers, environment and urban systems, v.18, n.5, p. 365-380, 1994.

INSTITUTO BRASILEIRO DE GEOGRAFIA E ESTATÍSTICA - IBGE. Base de informações por setor censitário: Resultados do Universo do Censo Demográfico 2000. Rio de Janeiro: IBGE, 2002a. CD-ROM.

INSTITUTO BRASILEIRO DE GEOGRAFIA E ESTATÍSTICA - IBGE. ESTATCART: Sistema de recuperação de informações georreferenciadas. Rio de Janeiro: IBGE, 2002b. CD-ROM.

INSTITUTO BRASILEIRO DE GEOGRAFIA E ESTATÍSTICA - IBGE. Vocabulário básico de recursos naturais e meio ambiente. 2.ed. Rio de Janeiro: IBGE, 2004. 332 p. http://www.ibge.gov.br/home/presidencia/noticias/ vocabulario.pdf. (21 fev. 2005).

INSTITUTO GEOGRÁFICO E CARTOGRÁFICO DO ESTADO DE SÃO PAULO IGC. Cartas base. Escala de 1:10.000. São Paulo, 1977, 1978 e 1979.

KOFFLER, N.F.; CAVALLI, A.C.; NOGUEIRA, F.P. Inventário canavieiro com auxílio de fotografias aéreas. Piracicaba: PLANALSUCAR, 1979. 38 p.

LEPSCH, I.F., coord. Manual para levantamento utilitário do meio físico e classificação de terras no sistema de capacidade de uso do solo. Campinas: SBCS, 1983. 175 p.

LEVY, M. do C.T.C. Avaliação de cenários da produção agrícola visando a sustentabilidade do uso das terras de Piracicaba (SP). Piracicaba, 1995. 104 p. Dissertação (Mestrado) - Escola Superior de Agricultura "Luiz de Queiroz", Universidade de São Paulo. 
LIMA-E-SILVA, P.P.; GUERRA, A.J.T.; MOUSINHO, P.; BUENO, C.; ALMEIDA, F.G.; MALHEIROS, T.; SOUZA JUNIOR, A.B. Dicionário brasileiro de ciências ambientais. Rio de Janeiro: Thex Editora, 1999. 247 p.

LIU, J.; TAYLOR, W.W. (Ed.). Integrating landscape ecology into natural resource management. New York: Cambridge University Press, 2002. 516 p.

LOCH, C. A interpretação de imagens aéreas: noções básicas e algumas aplicações nos campos profissionais. 2.ed. Florianópolis: Editora da UFSC, 1993. 120 p. (Série Didática)

LOMBARDI NETO, F.; MOLDENHAUER, W.C. Erosividade da chuva: sua distribuição e relação com as perdas de solo em Campinas (SP). Bragantia, v.51, n.2, p.189-196, 1992.

MACHADO, P.A.L. Direito ambiental brasileiro. 10.ed. São Paulo: Malheiros Editores, 2002. $1038 \mathrm{p}$.

MARTINI, L.C.P.; LANNA, A.E. Medidas compensatórias aplicáveis à questão da poluição hídrica de origem agrícola. Revista Brasileira de Recursos Hídricos, v.8, n.1, p.111-136, 2003.

McGARIGAL, K.; MARKS, B.J. FRAGSTATS: spatial pattern analysis program for quantifying landscape structure. Portland: U.S. Department of Agriculture, Forest Service, Pacific Northwest Research Station, 1995. 122 p. (Gen. Tech. Rep. PNWGTR-351)

McGARIGAL, K. Landscape structure and spatial pattern analysis for ARC/INFO: an overview of landscape ecology principles. Fort Collins, Colorado, out.1997. http://www.innovativegis.com/products/fragstatsarc/aboutlc.htm. (29 jul. 2002).

McGARIGAL, K. Landscape pattern metrics. In: El-SHAARAWI, A.H.; PIEGORSCH, W.W. (Ed.). Encyclopedia of Environmentrics. Sussex, England, John Wiley, 2002. v.2, p.1135-1142. http://www.umass.edu/landeco/pubs/pubs.html. (8 fev. 2005).

MORETTI, L.R. Avaliação da erosão superficial em pequenas bacias hidrográficas rurais. São Paulo, 2001. 128 p. Tese (Doutorado) - Escola Politécnica, Universidade de São Paulo. 
MORRIS, P.; THERIVEL, R. (Ed.) Methods of Environmental Impact Assessment. 2.ed. London: Spon Press, 2001. 508 p.

NEWSON, M.D. Land, water, and development: sustainable management of river basin systems. 2.ed. London: Routledge, 1997. 460 p.

OLIVEIRA, D.P.R. Planejamento estratégico: conceitos, metodologia e práticas. 14 ed. São Paulo: Atlas, 1999. 1 v.

OLIVEIRA, J.B. Solos da folha de Piracicaba. Campinas: Instituto Agronômico, 1999. 173 p. (Boletim Científico, 48).

RANIERI, S.B.L. Avaliação de métodos e escalas de trabalho para a determinação de risco de erosão em bacia hidrográfica utilizando Sistema de Informações Geográficas (SIG). São Carlos, 1996. 128 p. Dissertação (Mestrado) - Escola de Engenharia de São Carlos, Universidade de São Paulo.

RIBEIRO, F.L.; CAMPOS, S. Capacidade de uso da terra no Alto Rio Pardo, Botucatu (SP), através do sistema de informação geográfica. Revista Energia na $\begin{array}{llllll}\text { Agricultura, } & \text { v.14, } & \text { n.2, } & \text { p. } & \text { 48-60, } & 1999 .\end{array}$ http://www.fca.unesp.br/posgradua/Energia/revista/v14n2-99/142Fernanda.pdf. (5 jul. 2004).

ROCHA, J.V.; LOMBARDI NETO, F.; BACELLAR, A.A.A. Metodologia para determinação do fator comprimento de rampa (L) para a Equação Universal de Perdas de Solo. Caderno de Informações Georreferenciadas (CIG), v.1, n.2, 1997. http://www.cpa.unicamp.br/revista/cigv1n2n1.html. (5 jul. 2004).

ROSA, R. Introdução ao sensoriamento remoto. 4.ed. Uberlândia: Editora da Universidade Federal de Uberlândia, 2001. 210 p.

RUFFOLO, F.C. Mapeamento das fontes poluidoras da região rural do município de Piracicaba. Piracicaba, 2003. 34 p. Relatório final (Estágio profissionalizante) Escola Superior de Agricultura “Luiz de Queiroz”, Universidade de São Paulo.

SANTOS, R.F.; CARVALHAIS, H.B.; PIRES, F. Planejamento ambiental e sistemas de informações geográficas. Caderno de Informações Georreferenciadas (CIG), v.1, n.2, 1997. http://www.cpa.unicamp.br/revista/cigv1n2a2.html. (30 mar. 2005). 
SÃO PAULO (Estado). Decreto $\mathrm{n}^{\circ}$ 8.468, de 8 de setembro de 1976. Aprova o regulamento da lei $\mathrm{n}^{\circ}$ 907, de 31 de maio de 1976. http://www.daee.sp.gov.br/legislacao/decreto_8468.htm. (16 jan. 2004)

SÃO PAULO (Estado). Decreto n ${ }^{\circ}$ 10.755, de 22 de novembro de 1977. Dispõe sobre o enquadramento dos corpos de água receptores na classificação prevista no Decreto 8.468, de 8 de $\quad$ setembro 1976. http://www.daee.sp.gov.br/legislacao/decreto_10755.htm. (16 jan. 2004)

SÃO PAULO (Estado). Portaria do Centro de Vigilância Sanitária CVS 21, de 19 de dezembro de 1991. Disciplina o padrão bacteriológico das águas de irrigação de plantações de hortaliças e frutas rasteiras. Diário Oficial, São Paulo, 19 dez. 1991. http://www.cvs.saude.sp.gov.br/busca.asp?busca=CVS+21. (11 dez. 2003)

SÃO PAULO (Estado). Lei no 7.663, de 30 de dezembro de 1991. Estabelece normas de orientação à Política Estadual de Recursos Hídricos bem como ao Sistema Integrado de Gerenciamento de Recursos Hídricos. http://www.daee.sp.gov.br/legislacao/lei_7663.htm. (5 ago. 2004).

SÃO PAULO (Estado). Lei no 41.258, de 31 de outubro de 1996. Aprova o Regulamento dos artigos $9^{\circ}$ a 13 da Lei $\mathrm{n}^{\circ}$ 7.663, de 30 de dezembro de 1991. http://www.daee.sp.gov.br/legislacao/decreto_41258.htm. (5 ago. 2004).

SECRETARIA DE AGRICULTURA E ABASTECIMENTO DE PIRACICABA SEMA. Relatório 2002/2003. Projeto de pesquisa na bacia hidrográfica do Ribeirão dos Marins: levantamento da qualidade e quantidade de água e potencial para a implantação do programa de produção de alimentos e de recuperação ambiental. Piracicaba: SEMA, CENA, FEALQ, SEMAE, 2003. 63 p.

SERVIÇO MUNICIPAL DE ÁGUA E ESGOTO - SEMAE. Arquivo do cadastro de ruas e estradas (compact disc). Piracicaba, 2003.

SILVA, A.M.; SCHULZ, H.E. CAMARGO, P.B. Erosão e hidrossedimentologia em bacias hidrográficas. São Carlos: RiMa, 2003. 140 p.

SILVA, J.X. Geoprocessamento para análise ambiental. Rio de Janeiro: J. Xavier da Silva, 2001. 228 p. 
SIMÕES, L.B.; RIBEIRO, F.L.; DAINESE, R.C.; CARDOSO, L.G.; CAMPOS, S. Priority areas for riparian forest restoration in Southeastern Brazil. Scientia Forestalis, n.61, p. 113-121, 2002.

SLIVA, L.; WILLIAMS, D.D. Buffer zone versus whole catchment approaches to studying land use impact on river water quality. Water Research, v.35, n.14, p. 3462-3472, 2001.

TERAMOTO, E.R. Relações solo, substrato geológico e superfícies geomórficas na microbacia do ribeirão dos Marins (Piracicaba, SP). Piracicaba, 1995. 93 p. Dissertação (Mestrado) - Escola Superior de Agricultura "Luiz de Queiroz", Universidade de São Paulo.

TERAMOTO, E.R.; LEPSCH, I.F.; VIDAL-TORRADO, P. Relações solo, superfície geomórfica e substrato geológico na microbacia do ribeirão Marins (Piracicaba SP). Scientia Agrícola, v.58, n.2, p.361-71, 2001.

TOLEDO, A.M.A. Evolução espaço-temporal da estrutura da paisagem e sua influência na composição química das águas superficiais dos ribeirões Piracicamirim e Cabras (SP). Piracicaba, 2001. 94 p. Dissertação (Mestrado) - Centro de Energia Nuclear na Agricultura, Universidade de São Paulo.

TURNER II, B.L.; MEYER, W.B., (Ed.). Changes in land use land cover: a global perspective. Cambridge: Cambridge University Press, 1994. 537 p.

TURNER, M.G. Landscape ecology: the effect of pattern on process. Annual Review of Ecology and Systematics, v.20, p.171-197, 1989.

TURNER, M.G.; GARDNER, R.H. Quantitative methods in landscape ecology: the analysis and interpretation of landscape heterogeneity. New York: Springer Verlag, 1990. 536 p. (Ecological Studies, 82)

TURNER, M.G.; GARDNER, R.H.; O'NEILL, R.V. Landscape ecology in theory and practice: pattern and process. New York: Springer-Verlag, 2001. 401 p.

VETTORAZZI, C.A. Sensoriamento remoto orbital. Piracicaba, 1992. n.2. 134 p. Apostila. Departamento de Engenharia Rural, Escola Superior de Agricultura "Luiz de Queiroz”, Universidade de São Paulo. (Série Didática) 
VON SPERLING, M. Introdução à qualidade das águas e ao tratamento de esgotos. 2.ed. v.1. Belo Horizonte: Departamento de Engenharia Sanitária e Ambiental DESA, Universidade Federal de Minas Gerais - UFMG, 1996. 243 p. (Princípios do tratamento biológico de águas residuárias)

WALSH, C.J.; SHARPE, A.K.; BREEN, P.F.; SONNEMAN, J.A. Effects of urbanization on streams of the Melbourne region, Victoria, Australia. I. Benthic macroinvertebrate communities. Freshwater Biology, v.46, p. 535-551, 2001.

WANG, L.; LYONS, J.; KANEHL, P. Impacts of urbanization on stream habitat and fish across multiple spatial scales. Environmental Management, v.28, n.2, p. 255266, 2001.

WETZEL, R.G. Limnology. Philadelphia: W. B. Saunders Company, 1975. 743 p.

WISCHMEIER, W.H.; JOHNSON, C.B.; CROSS, B.V. A soil erodibility nomograph for farmland and construction sites. Journal of Soil and Water Conservation, v.26, n.5, p.189-193, 1971.

WISCHMEIER, W.H.; SMITH, D.D. Predicting rainfall erosion losses: a guide to conservation planning. Washington: Department of Agriculture, 1978. 47 p. (USDA. Agriculture Handbook, 537). 